UNIVERSIDADE DE SÃO PAULO

\title{
JUSTIÇA DE TRANSIÇÃO NA GUINÉ-BISSAU - O PAPEL DAS OPERAÇÕES DE MANUTENÇÃO DA PAZ
}

Claudina Augusta Tavares Viegas

Faculdade de Direito

São Paulo 


\title{
JUSTIÇA DE TRANSIÇÃO NA GUINÉ-BISSAU - O PAPEL DAS OPERAÇÕES DE MANUTENÇÃO DA PAZ
}

\author{
Claudina Augusta Tavares Viegas
}

Dissertação apresentada à Faculdade de Direito da Universidade de São Paulo como requisito parcial à obtenção do título de Mestre em Direito.

Área de Concentração: Direito Internacional

Professora Orientadora: Cláudia Perrone-Moisés

\section{Faculdade de Direito}

\section{São Paulo}

2013 


\section{TERMO DE APROVAÇÃO}

Nome: Claudina Augusta Tavares Viegas

Título: Genocídio e o Tribunal Penal Internacional para Ruanda

Dissertação apresentada à Faculdade de Direito da Universidade de são Paulo como requisito parcial à obtenção do título de mestre em Direito.

Área de Concentração: Direito Internacional

Data de aprovação:

Banca examinadora: 


\section{AGRADECIMENTOS}

A Deus, acima de todas as coisas.

Ao Brasil e à Gloriosa velha e sempre nova São Francisco.

À minha querida Orientadora, a professora Cláudia Perrone-Moisés, sem palavras para agradecer todo o apoio prestado e toda a paciência em acompanhar e orientar o trabalho.

Ao Querido Professor Umberto Celli por todo o apoio e orientação ao longo da vida acadêmica.

Aos meus adorados pais, Augusto e Liberata e irmão e sobrinho, Abdel e Samir pelo amor imensurável desde sempre.

Ao David, pelo carinho, atenção, companheirismo, paciência e amor dispensados desde o primeiro momento.

Ao Miguel, pela paciência, a amizade, as dicas, conselhos e idéias, e

Aos amigos, que após tantos anos se transformaram em família: Nianga, Anita, Eduarda, Gawar, Sãozinha, Mininú, Vladimir, Aladje e Paulo. 
“A paz não é mera ausência de guerra, mas é uma virtude que nasce de um estado de espírito, uma disposição para a benevolência, confiança, justiça”.

- Baruch Spinoza 


\section{RESUMO}

A Presente dissertação de mestrado analisa o papel da justiça de transição na busca pela paz na Guiné-Bissau, a partir do estudo dos mecanismos de justiça de transição existentes. Estudam-se os mecanismos existentes na busca pela paz e prestação de contas pelo passado de abusos e violações de direitos humanos e a escolha feita pela Guiné-Bissau pela operação de manutenção da paz, UNOGBIS constituída pela Organização das Nações Unidas. Nesses termos é apresentado o referêncial teórico necessário ao entendimento das questões propostas; é realizada a contextualização do país no continente africano e posteriormente é analisado o mecanismo das operações da paz, enquanto atividade de fortalecimento do processo de reconciliação nacional por meio da execução de projetos destinados a recompor as estruturas institucionais, a recuperar a infra-estrutura física e a ajudar na retomada da atividade econômica.

PALAVRAS-CHAVE: Justiça de transição; Guiné-Bissau; operação de manutenção da paz; África; paz. 


\begin{abstract}
This dissertation examines the role of transitional justice in the search for peace in Guinea-Bissau, from the study of the mechanisms of transitional justice existent. It is studied the existing mechanisms in the search for peace and accountability for past abuses and violations of human rights. And also, the choice made by Guinea-Bissau for the peacekeeping operation, UNOGBIS formed by the United Nations. In these terms the theoretical reference is made to the understanding of the issues proposed; contextualization is held in the country on the African continent and it is later analyzed the mechanism of peace operations, while strengthening the activity of the national reconciliation process through the implementation of projects aimed recompose the institutional structures to regain physical infrastructure and help the recovery of economic activity.
\end{abstract}

KEYWORDS: Transitional justice; Guinea-Bissau; peacekeeping operation; Africa, peace. 


\section{LISTA DE ABREVIATURAS}

ANC - African National Congress

CEDEAO - Comunidade Econômica dos Estados Oeste Africanos

CPLP - Comunidade de Países de Língua Portuguesa

ECOMOG - Grupo de Monitoramento da Comunidade Econômica dos Estados do

Oeste da África

FPR - Frente Patriótica de Ruanda RPF

IFP - Inkhatha Freedom Party

ONU - Organização das Nações Unidas

OUA - Organização da Unidade Africana

PAIGC - Partido Africano para a Independência da Guiné e Cabo-verde

PAC - Pan Africanist Congress

MFDC - Movimento das Forças Democráticas de Casamansa

MONUC - Missão da Organização das Nações Unidas na República Democrática do Congo

UA - União Africana

UNAMIR - United Nations Assistant Mission for Rwanda (Missao de Assistência das Nações Unidas para Ruanda)

UNICTR - Tribunal Penal Internacional para Ruanda 


\section{SUMÁRIO}

\section{Conteúdo}

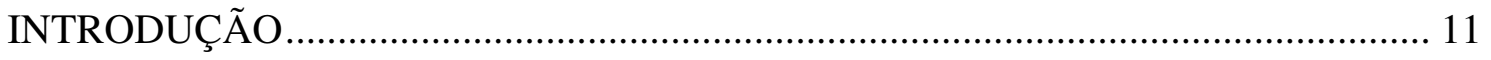

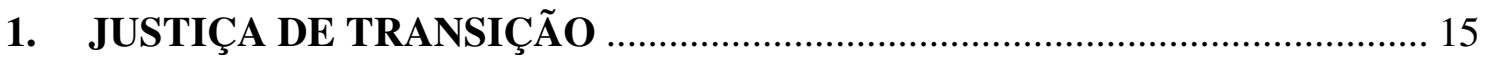

1.1 Conceito de justiça de transição.................................................................. 18

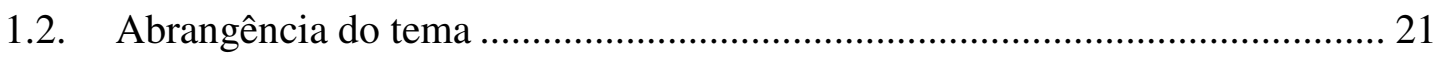

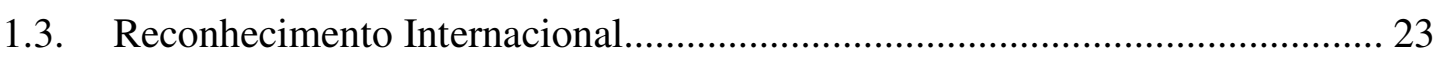

1.4. Fases e modalidades ou concepções que podem ser aplicadas no âmbito da

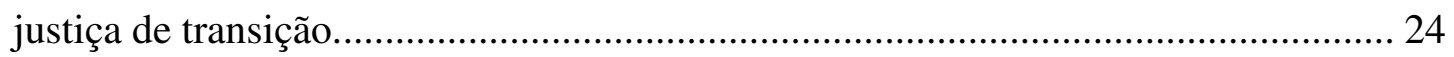

1.4.1. Modalidades ou concepções de justiça de transição................................... 24

1.4.2. Mecanismos de busca da verdade............................................................. 28

1.5. O Elemento "justiça" na justiça de transição ................................................. 31

1.5.1. Papel do Direito em períodos de transição ............................................. 31

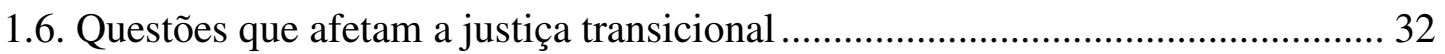

2. O PROCESSO DE TRANSIÇÃO GUINEENSE …...................................... 35

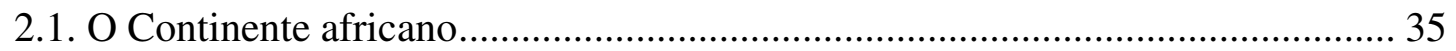

2.2. A Guiné-Bissau: entendendo a (eterna) transição guineense ........................... 52

2.3. Fatores históricos: antecedentes do conflito de 1998 - a descolonização e suas consequências

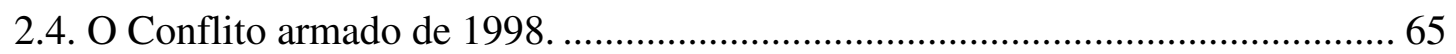

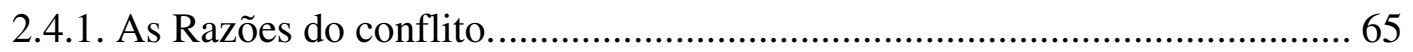

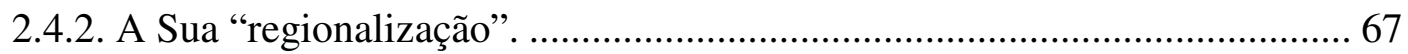


2.7. O Papel da Organização da Unidade Africana e das organizações regionais. .... 73

2.8. A Organização das Nações Unidas (ONU) e os conflitos na Guiné-Bissau importância da ONU.

2.8.1. Análise das resoluções do Conselho de Segurança da ONU sobre a Guiné-

Bissau de 1999 a 2012.

3. O PAPEL DAS OPERAÇÕES DE PAZ NA JUSTIÇA DE TRANSIÇÃO .... 85

3.1. As Operações de paz da Guiné-Bissau: UNOGBIS - UNIOGBIS (Apartir de 1999), e ECOMOG (1999). 108

3.2. Importância das operações de paz e das organizações internacionais envolvidas.

4. JUSTIÇA DE TRANSIÇÃO COMO INSTRUMENTO DA PAZ E DA

DEMOCRACIA 128

4.1. Os Esforços de (re) construção da paz..... 128

4.2. O papel das organizações da sociedade civil na construção da paz.

CONCLUSÃO 


\section{INTRODUÇÃO}

Ao Término de um regime político caracterizado por violações e abusos constantes e graves de direitos humanos, quando se procede ao restabelecimento de um novo regime, se pretende que seja diferente do anterior. No entanto, tal renovação implica na necessidade da reorganização e regulação dos setores mais atingidos pelo antigo regime e por vezes, dependendo da situação, na reorganização de todos os setores chave daquela sociedade. Para que se ultrapasse um período caracterizado por constantes abusos e opressão, são necessárias medidas jurídicas, políticas e sociais que façam com que as instituições retornem ou se tornem minimamente liberais e estabeleçam algum sentido de justiça. A ideia de justiça de transição surge nesse sentido, superar um regime de opressão e abuso, a partir de um processo construtor ou reconstrutor do país, que aplique medidas específicas que garantam a justiça e a integridade da população.

De acordo com Julia Monteath de França ${ }^{1}$, para que um povo se constitua como nação, faz-se necessária a formulação de um ideário nacional que precisa ser permanentemente reformulado e adaptado às vivências e experiências do grupo a que se reporta. Para a autora, um dos elementos mais importantes para a autoafirmação como nação é a memória nacional, associada à autoimagem dominante em cada período da história nacional. A noção de memória, que muitas vezes remete à idéia de lembrança, passa necessariamente pela construção do esquecimento - esquecimento este que recorrentemente recai sobre o campo político. Toda e qualquer sociedade, ao selecionar aquilo que acredita valer a pena lembrar-se e, ao mesmo tempo, aquilo de que acredita ser melhor esquecer, estabelece uma relação com seu passado a partir da qual este se

\footnotetext{
${ }^{1}$ FRANÇA, Julia Monteath de. A Transição Democrática e a Construção da Memória Política na África do Sul e na Argentina. Revista Eletrônica Boletim do Tempo, Ano 5, Noo5, Rio, 2010.
} 
reconstrói e passa a afetar ativamente o processo de reformulação da identidade, bem como as formas de conduta da população. Assim, a construção da memória coletiva, ou memória social, de certa forma também influência a relação da sociedade com o futuro. No entanto, este processo de construção não pode ser visto como uma repetição exata do passado, mas sim como uma permanente reconstrução de experiências vividas que se dá a partir da interação dos atores sociais envolvidos e que depende de diversos fatores para acontecer. A criação de uma memória social é uma importante parte do processo de construção da identidade nacional, é ela que determina a percepção da política nacional e dos objetivos políticos a longo prazo e é com ela que os atores sociais, no seu conjunto, aprendem com essas recordações . Uma situação em que esse momento de construção ou reconstrução da identidade nacional, a partir da criação de uma memória social é facilmente percebido é o da transição de regimes autoritários para a democracia, por meio de instrumentos jurídicos, politicos e sociais específicos e é este tipo de transição que será tratado no presente trabalho. O tema envolve não apenas questões políticas, mas também éticas, e vale dizer que os métodos utilizados, para se realizar a justiça de transição, variam de Estado para Estado: podem ser encontrados na anistia e nos perdões, em tribunais de conciliação ou, ainda, no julgamento dos acusados e das instituições estatais envolvidas na repressão, como se analisará mais adiante. É justamente por se tratar de uma situação de mudança, de ruptura com o passado, que a sociedade se vê impelida a lidar com a realidade autoritária do momento anterior, de modo que, se possa construir um novo regime, um regime democrático, que não esqueça o passado, mas que queira construir um futuro diferente. Deste modo, é crucial entender como a sociedade vai lidar com o regime anterior, principalmente no que diz respeito às violações dos direitos humanos cometidas durante aquele regime. Quer-se com isso dizer que, em uma situação de ruptura com o passado violento, marcado por 
abusos, cabe àquela sociedade a utilização de mecanismos que permitam ajustar contas com o passado de forma a construir ou reconstruir uma memória social, e uma nova sociedade, livre do espectro do passado.

No caso da Guiné-Bissau, a questão da transição se apresenta "delicada". Tratase de um país "jovem”, cuja tomada de independência do colonialismo data de 1974, e que tem apresentado algumas dificuldades em lidar com o passado de violência que caracterizou, de forma marcante a sua história, e que ainda parece influenciar o presente. Quando se decidiu pelo tema, uma das questões mais "incômodas" era a influência que o passado violento da Guiné-Bissau continua a ter no presente, e como mecanimos de justiça de transição poderiam ajudar a alijar tal situação. O caso Guineense se afirma de difícil caracterização na medida em que, apesar dos vários esforços realizados, o retorno à violência e/ou a utilização de medidas antidemocráticas é recorrente, dificultando o processo de transição. Períodos de calmaria e implementação de medidas que tentam estabelecer uma ruptura com os períodos de violência, acabam sendo seguidos por situações totalmente violadoras do Estado de Direito, dificultando a identifição da situação de transição em período especifico ou em período que aconteceria até hoje. Dessa forma faz-se necessária uma analise acurada dos fatos, de forma a identificar o período de transição e os métodos utilizados. O tema não é pacífico na doutrina, na medida em que há na literatura, quem defenda que existem duas fases que marcam a transição guineense, e há quem defenda uma única fase, como se analisará mais adiante. O objetivo do presente trabalho é então, em um primeiro momento identificar o período pelo qual passa o país, para posteriormente analisar se a transição política é efetivamente acompanhada de medidas de justiça transicional, de forma a identificar a forma como esta tem sido realizada. Dessa forma, o presente trabalho tem por proposta apresentar e analisar as diferentes concepções de 
justiça de transição e a opção realizada pela Guiné-Bissau. Na medida em que, à primeira vista o país parece se encontrar ainda em transição, o presente trabalho visa identificar se realmente se pode falar em transição na Guiné-Bissau ou se é necessário instaurar uma verdadeira transição. E ainda, do que depende tal possibilidade, considerando-se que a justiça de transição pode ser um auxiliar na busca pela paz e consolidação dos valores democráticos. Para proceder ao estudo acima proposto, a primeira parte do trabalho apresenta o referencial teórico necessário ao entendimento das características e natureza da questão basilar que permeia o trabalho: a justiça de transição. Para tal, se apresentam as principais concepções de justiça de transição existentes na doutrina internacional, as modalidades que a caracterizam, e as fases de evolução do conceito. A segunda parte trata do processo de transição na Guiné-Bissau. O País é contextualizado na realidade continental e regional em que se insere para posteriormente se apresentar e discutir a transição democrática na Guiné-Bissau e a prática da justiça de transição. Para tal, se examina o período de violência correspondente ao conflito político militar de 1998/1999, e a situação do país do pósguerra aos dias atuais. A análise compreende ainda o período imediato à tomada de independência, na medida em que se faz necessário à contextualização do período em estudo e à compreensão dos motivos que estão na base e origem do conflito. A terceira parte aborda as operações de paz enquanto método multifacetado e abrangente de colocar em prática a justiça de transição e a escolha por este método, realizada pela Guiné-Bissau. A quarta parte trata da importância da justiça de transição na busca pela paz e fortalecimento dos valores democráticos e antecede a conclusão. Vale dizer que no presente trabalho as expressões "Operação de paz" ou "operação de manutenção da paz" são empregadas insdiscriminadamente para designar de modo geral as missões de paz. 


\section{JUSTIÇA DE TRANSIÇÃO}

Com o fim da guerra fria, diversos países passaram por transições políticas radicais. Em cada um dos diferentes casos, as questões relativas à transição foram enfrentadas de formas diversas, que revelaram os diferentes interesses e valores envolvidos, e por consequência resultados e concepções diferentes de justiça de transição. Ou seja, foi apartir do final da Guerra fria, após os horrores da Segunda Grande Guerra, que se desenvolveram ou aperfeiçoaram os métodos ou mecanismos específicos para lidar com o passado através do enfrentamento dos graves abusos e violações de direitos humanos ocorridos na época. Tal foi realizado com o objetido de instaurar um clima de justiça e confiança, e evitar que novos conflitos com a capacidade de destruição e aniquilação dos anteriores voltassem a acontecer.

É nesses termos que surge a expressão “justiça de transição”. Cunhada por Ruti G. Teitel, de acordo com a mesma², em 1991, na época após o colapso da União Soviética e na qual estavam em curso as transições democráticas na América Latina, a expressão refere-se exatamente aos mecanismos instaurados para se enfrentar abusos e violações do passado e reconstruir uma nova sociedade, como anteriormente mencionado. A autora firma que, ao propor tal terminologia, tinha por objetivo explicar e /ou comentar a então tímida construção de uma concepção distinta de justiça, associada a períodos de mudanças políticas radicais seguintes a regimes opressivos ${ }^{3}$. Para Fabrice Hourquebie ${ }^{4}$, a justiça de transição surge ao lado da justiça tradicional-institucional, como uma forma de justiça regulamentar e sancionatória de carácter excepcional, na medida em que

\footnotetext{
${ }^{2}$ TEITEL, Ruti, G. Editorial Note - Transitional Justice Globalized, In The international Journal of Transitional Justice, Oxford Journals, Volume 2, Issue 1, Pág. 1.

${ }^{3}$ TEITEL, Ruti, G. Op. Cit. Pág. 1.

${ }^{4}$ HOURQUEBIE, Fabrice, La notion de justice transitionnelle - a-t-elle un sens ?, Toulouse.
} 
surge após o regime opressivo, mas vale dizer, sempre em consonância com os valores de democraia e Estado de Direito, que ela mesma persegue. Ainda para o autor, em um contexto internacional de luta contra a impunidade e esperada punição de grandes violações dos direitos humanos, a justiça de transição goza de um estatuto especial, que coexiste com a justiça comum. $\mathrm{O}$ autor defende que na verdade, a justiça transicional é baseado em uma justiça mais ampla e profunda, que não se baseia apenas na função punitiva, mas na construção de uma memória social, apartir dos mecanismos de busca da verdade e reconciliação, como se vê com as Comissões de Verdade, e a busca de uma paz sustentável, do estabelecimento do Estado de direito, da democracia e de uma cultura de respeito aos direitos humanos, através de uma ampla gama de mecanismos judiciais e não judiciais.

Para John Elster ${ }^{5}$, a justiça transicional tem uma história que remonta ao período da democracia ateniense de 411 e 403 a.c. A referência aparece na experiência ateniense em 411 e entre 404 e 403 a.C., quando ocorre a passagem da democracia à oligarquia, e posteriormente a volta dos democratas ao poder. Pode-se considerar que os mecanismos de justiça transição utilizados foram a punição e a reparação e embora não houvesse, um termo específico que caracterizasse os mecanismos utilizados, a busca de reconciliações, na época, já trazia características que hoje se encontram catalogadas. Após os experimentos atenienses, o mesmo autor só encontra episódios "significativos" de justiça transicional em meados do século XX, no final da Primeira Guerra Mundial, mas esta adquire realmente importância, quando com o fim da Segunda Guerra Mundial se inicia a transição para a democracia.

\footnotetext{
${ }^{5}$ ELSTER, John, Closing the Books: Transitional Justice in Historical Perspective, Cambridge University Press, New York, 2004, Apud, BOSIRE, Lydiah Kemunto, Grandes promessas, pequenas realizações: justiça transicional na África subsaariana, Revista internacional de direitos humanos: SUR, São Paulo, v. 3, n. 5, 2006, Pág. 73. Disponível em http://bdjur.stj.gov.br/xmlui/bitstream/handle/2011/22642/grandes_promessas_pequenas_realizacoes.pdf? sequence $=1$. Acesso em: 20/05/2011.
} 
Já a análise de Ruti Teitel começa com as transições modernas e não remonta à antiguidade $^{6}$. Para a autora, a noção moderna de justiça transicional foi criada e cristalizada ao final dos anos 1980 e início dos anos 1990, identificada com um debate vital sobre a possibilidade de punir regimes predecessores opressores, particularmente à luz dos objetivos da democracia e da construção do Estado associados às transições políticas da época e está relacionada ao papel do Direito em tempos de mudanças politicas radicais ${ }^{7}$.

Apesar da importância do conhecimento histórico, é assente na doutrina a idéia do surgimento da justiça de transição, nos moldes em que é conhecida, no final do Século $\mathrm{XX}$, na medida em que, os fundamentos ou as primeiras discussões acerca do tema podem ser encontrados nos debates realizados no Pós-Segunda Guerra Mundial, quando ocorreram as negociações que culminaram com a criação da ONU, a elaboração da Declaração Universal dos Direitos do Homem e a criação do Tribunal de Nuremberg. Nesses termos, pode-se considerar que a delimitação do conceito de justiça de transição é relativamente recente datando do século XX.

Vale chamar atenção para o fato de não se tratar de uma coincidência o conceito de justiça de transição ter sido sedimentado no século XX, após a Segunda Guerra Mundial. Após os horrores acontecidos no referido conflito, no qual foram cometidos massacres e atrocidades contra o ser humano a uma escala virtiginosa, verificou-se um aumento crescente de reconstruções democráticas. Na América latina começou a decadência dos regimes autoritários, na África e na Ásia ocorreram as transições póscoloniais. Ou seja, um pouco por todo o mundo, ocorriam mudanças estruturais. A época ficou marcada pela decadência de vários regimes autoritários e opressivos e a

\footnotetext{
${ }^{6}$ TEITEL, Ruti, G. Transitional Justice Genealogy, Harvard Human Rights Journal, Vol.16, N.69, 2003, Pág. 71.

${ }^{7}$ TEITEL, Ruti, G. Op. Cit. Pág. 1.
} 
criação de diferentes tipos de democracia. A nível mundial percebeu-se a importância de se evitar os horrores da guerra, seja criando mecanismos que os combatessem ou previnissem, ou lidassem com eles de forma a levá-los a termo, seja construindo sociedades mais justas que valorizassem uma paz duradoura.

O Termo "justiça de transição" foi, então, criado como resultado da necessidade que a comunidade internacional sentiu de fazer frente às barbaries cometidas, através de mecanismos que favorecessem o não esquecimento desses acontecimentos, e criassem um clima de justiça. Vale ainda dizer, que apesar da história da humanidade ser marcada por guerras e conflitos de várias ordens, a existência de vestígios de mecanismos, datando da antiguidade, que podem ser considerados como precursores do que hodiernamente se entende por justiça de transição, demonstra que ao mesmo tempo em que sempre fez guerra, o ser humano sempre teve a preocupação em tentar fazer a paz, a justiça, em enfrentar os seus próprios erros e construir um futuro e uma sociedade melhor ou menos iníqua.

\subsection{Conceito de justiça de transição}

De acordo com Ruti Teitel ${ }^{8}$, a justiça transicional pode ser definida como a concepção de justiça associada a períodos de mudança política, caracterizada por respostas legais para confrontar os delitos de regimes repressores predecessores. Para Kai Ambos ${ }^{9}$, A justiça de transição pode ser considerada como um método de

\footnotetext{
${ }^{8}$ TEITEL, Ruti, G. Transitional Justice Genealogy, Harvard Human Rights Journal, Vol.16, N.69, 2003, p. 71.

AMBOS, Kai. El marco jurídico de la justicia de transición. In: MALARINO, Ezequiel; ELSNER, Gisela (Org.). Justicia de Transición: com informes de América Latina, Alemania, Italia y España. Montevideo: Fundación Konrad-Adenauer-Stiftung, 2009. Pág. 23.
} 
restabelecimento da reconciliação da sociedade que passou por experiências traumáticas, consistindo, na busca pela efetivação da justiça, da punição e responsabilização dos que violaram os Direitos dos cidadãos, e na garantia de que aqueles que sofreram violência por parte dos agentes estatais em períodos autoritários sejam reconhecidos pelo Estado como vítimas e suas histórias sejam resgatadas.

Na mesma senda segue Dimitri Dimoulis ${ }^{10}$, que considera que a justiça de transição implica na atribuição de responsabilidades e quando possível na punição dos responsáveis pelos crimes. Ainda para o autor, a questão da justiça de transição que aparentemente se trata de questão política torna-se, também, jurídica, na medida em que concerne ao modo como serão apuradas as responsabilidades e filosófica, porque se relaciona à busca de justificativas plausíveis às apurações. Já Pablo de Greiff ${ }^{11}$ entende a justiça de transição como um conjunto de medidas que visam a reparar abusos massivos de direitos humanos, que normalmente incluem processos criminais, comissões de verdade, reparações e certos tipos de reforma institucional, mas tal lista de medidas varia, assim como é relativa a importância de cada uma das medidas e particular o ponto da sua implementação. Ainda de acordo com Neil kritz e à semelhança do que consta na Macmillan's Encyclopedia of Genocide and Crimes against Humanity $^{12}$, A justiça transicional pode ser definida como um campo de atividade e de inquirição focalizado na maneira pela qual as sociedades encaminham casos passados de abusos de direitos humanos, num esforço para combater a

${ }^{10}$ DIMOULIS, Dimitri. Justiça de transição e função anistiante no Brasil: hipostasiações indevidas e caminhos de responsabilização. In MARTINS, Antonio; SWENSSON JUNIOR, Lauro Joppert (Org.). Justiça de transição no Brasil: direito, responsabilização e verdade. São Paulo: Saraiva, 2010. Pág. 92.

${ }^{11}$ GREIFF, Pablo de, DUTHIE, Roger (Ed.), Transitional Justice and Development: Making Connections (Advancing Transitional Justice), Social Science Research Council, 2009, Pág. 19.

${ }^{12}$ Macmillan's Encyclopedia of Genocide and Crimes against Humanity, out. 2004. e KRITZ, Neil, Transitional Justice: How Emerging Democracies Reckon with Former Regimes, Washington, D.C.: US Institute for Peace, 1995 BOSIRE, Apud, Lydiah Kemunto, Grandes promessas, pequenas realizações: justiça transicional na África subsaariana, Revista internacional de direitos humanos: SUR, São Paulo, v. 3, n.5, 2006, $\quad$ Pág. $73 . \quad$ Disponivel em :http://bdjur.stj.gov.br/xmlui/bitstream/handle/2011/22642/grandes_promessas_pequenas_realizacoes.pdf ?sequence=1. Acesso em: 20/05/2011 
impunidade e promover a reconciliação durante um período de mudança definitiva no panorama político. Em outras palavras, a justiça transicional abrange o estudo de como as sociedades lidam com um passado de violência e abuso de direitos humanos, levando em conta aspectos como, por exemplo, como punir os responsáveis, reparar as vítimas, curar as possíveis divisões sociais e ideológicas, e como lembrar o passado.

A Justiça transicional parte do princípio de que graves violações dos direitos humanos e atos de atrocidades em massa devem ser abordados, e trata da variedade de mecanismos que têm sido elaborados e empregados com vista a realizar a transição. Como nos ensina Rute Teitel, a justiça transicional consagra-se à construção de uma identidade política para o Estado cujo regime se haverá de construir:

“A justiça de transição oferece uma forma de reconstituir o coletivo (através daqueles que seriam potencialmente seus aspectos de divisão. Ou seja, os aspectos raciais, étnicos e religiosos) com base em uma identidade política que aflora de legados de medo e injustiça ${ }^{13}$.

Isto é, a justiça de transição permite a reconstrução de um ideário nacional político e social baseado nos princípios da democracia, do Estado de Direito e do respeito aos direitos humanos, levando em conta o respeito à realidade (cultura) do local em que será realizada. Ou seja, a justiça de transição permite que ao se lidar com o passado se possa trabalhar as origens do conflito, as questões que estão na base do conflito, de forma a superá-lo. Percebe-se, então, que em termos gerais, a justiça de transição é um conjunto de medidas, métodos ou mecanismos judiciais e extrajudiciais adotados por países em

13 TEITEL, Ruti, G. Transitional Justice, Oxford University Press, 2000. Pág. 225, “ Transitional justice offers a way to reconstitute the collective-across potentially divisive racial, ethnic, and religious lines that is grounded in a political identity that arises from the society's particular legacies of fear and injustice". 
momentos de mudanças institucionais profundas, para lidar com um passado abusivo e repressivo, ou um trauma social profundo, como uma guerra civil, de forma a evitar a impunidade e reparar as vítimas. Pode incluir ou não punições e parte do principio que é dever do Estado abordar o passado conturbado, o qual ele próprio tenha criado ou tenha sido omisso em evitar e garantir que a justiça, a verdade, reparações e reformas sejam concretizadas. Como marco do fim de um regime, geralmente totalitário ou opressivo e o início de outro que se quer diferente do primeiro, a justiça de transição busca a reconciliação social, a construção de um futuro e a reorganização da sociedade com base em valores novos de respeito aos direitos humanos e prestação de contas pelos erros cometidos.

\subsection{Abrangência do tema}

A Justiça de transição foi teorizada e conceituada apartir do estudo comparado das diversas experiências históricas de ruptura de regimes e dos valores político, jurídicos e sociais que os sustentavam e da forma como os respectivos países lidaram com tal ruptura. Nas palavras de Flávia Piovesan ${ }^{14}$, a justiça de transição lança o delicado desafio de como romper com o passado autoritário e viabilizar o ritual de passagem à ordem democrática. Alicerçada na reforma das instituições, na reparação às vítimas, na revelação da verdade factual, e na implementação de medidas de justiça, a justiça de transição tem por objetivo a reconstituição do Estado e da sociedade.

\footnotetext{
${ }^{14}$ PIOVESAN, Flávia Piovesan, Direitos Humanos: memória, verdade e justiça. Teoria e Debate no 87 março/abril 2010, Disponível em: http://www.fpabramo.org.br/o-que-fazemos/editora/teoria-edebate/direitos-humanos-memoria-verdade-e-justica, Acessado em: 23/06/2011.
} 
Com o decorrer do tempo, o campo da justiça transicional se tem desenvolvido e ampliado. Os elementos da justiça transicional passaram de uma aspiração do imaginário à expressão de obrigações legais vinculantes. O direito internacional, particularmente na aplicação a ele dada em organismos como o Tribunal Europeu dos Direitos Humanos, a Corte Interamericana de Direitos Humanos e o Comitê de Direitos Humanos, evoluiu com o passar dos últimos vinte anos até o ponto em que atualmente existem padrões claros relativos às obrigações dos estados a respeito da forma de enfrentar as violações dos direitos humanos, bem como proibições, como no caso das anistias gerais quando se trata de crimes internacionais. Tal fato foi amparado pela ratificação por mais de cem países da criação da Corte Penal Internacional que exije que cada signatário responda de maneira adequada às violações dos direitos humanos, sob pena de defrontar-se com uma ação legal por parte da Corte ${ }^{15}$.

Nesse sentido, a Justiça de Transição tem um papel cada vez mais amplo e significativo na busca pela e pela reconstrução da sociedade, com efeitos práticos:

(i) A Reconstrução do Estado, através da remoção dos perpetradores de cargos politicos, da realização de reformas e da justiça constitucional, como preconizado por Ruti Teitel. A Realização de atividades de DDR (Desarmamaento, desmobilização e reintegração),

(ii) A Restauração da confiança nas instituições estatais, a consolidação da democracia, a criação de museus como forma de confrontar o passado e não permitir o seu esquecimento são algumas das atividades relacionadas ao tema.

\footnotetext{
15 ZYL, Paul Van, Promovendo a justiça transicional em sociedades pós-conflito, In Revista Anistia
} Política e Justiça de Transição(jan. / jun. 2009). -- Brasília : Ministério da Justiça , 2009, Pag 32. 


\subsection{Reconhecimento Internacional}

A Justiça de transição tem aceitação internacional reconhecida pela figura da ONU.

Tal reconhecimento se encontra patente no relatório sobre $O$ Estado de Direito e a Justiça Transicional nas sociedades pós-conflito de 03 de Agosto 2004 do Secretário Geral da ONU em que se expõe o foco das Nações Unidas sobre as questões da justiça transicional e no qual constam explicitamente as seguintes recomendações ${ }^{16}$ :

(i) Garantir que as considerações sobre o Estado de Direito e a justiça de transição sejam integradas no nosso planejamento estratégico e operacional de operações de paz.

(ii) Fazer propostas para a melhoria dos arranjos do sistema das Nações unidas de forma a apoiar (...) a justiça transicional em sociedades em conflito e pós-conflito.

A ONU inclui como mecanismos judiciais de justiça de transição o Tribunal Internacional de Justiça, o principal órgão judicial das Nações Unidas, os tribunais penais ad hoc e os tribunais híbridos. Pode-se ainda considerar a aceitação destes mecanismos por parte dos Estados Membros como reconhecimento implícito da justiça de transição através dos seus mecanismos.

Vale, ainda, ressaltar que a justiça de transição foi diretamente influenciada pela atuação das organizações defensoras dos direitos humanos ${ }^{17}$.

\footnotetext{
${ }^{16}$ Relatório do Secretário Geral S/2004/616 -NAÇÕES UNIDAS - Conselho de Segurança. O Estado de Direito e a justiça de transição em sociedades em conflito ou pós-conflito.

${ }^{17}$ A Corte Interamericana de Direitos Humanos teve uma grande contribuição em fazer constar da definição de justiça transicional as obrigações legais de um Estado após um período de graves violações dos direitos humanos.
} 
1.4. Fases e modalidades ou concepções que podem ser aplicadas no âmbito da justiça de transição.

\subsubsection{Modalidades ou concepções de justiça de transição}

Ao Longo da sua obra, Rute Teitel analisa as diferentes concepções de justiça associadas à justiça de transição, além da punição penal ou justiça penal à qual a justiça de transição é comumente ligada. A autora analisa, então:

(i) A justiça criminal

(ii) O papel das investigações históricas (ou justiça histórica);

(iii) As políticas de reparação (ou justiça reparatória);

(iv) As medidas administrativas (ou justiça administrativa) e;

(v) A reforma constitucional (ou justiça constitucional de transição) ${ }^{18}$.

No que concerne à justiça criminal, a autora afirma que o papel desta na justiça de transição transcende, ultrapassa o de punição convencional e vai além das preocupações da justiça criminal comum. $\mathrm{O}$ que distingue medidas criminais transicionais é a sua tentativa de fundamentar e consolidar mudanças normativas. A justiça criminal é um ritual de liberalização dos Estados quando realizada através de praticas, cujas normas sejam publicamente explicadas e fundamentadas. A autora considera que, embora se veja a punição como justificativa para ajudar a estabelecer uma ordem democrática, deve-se levar em conta que a aplicação da lei ex post facto, em muitas circunstâncias, também vai contra o Estado de Direito ${ }^{19}$.

\footnotetext{
${ }^{18}$ TEITEL, Ruti, G. Op. Cit. Pág. 27-212.

${ }^{19}$ Ibidem.
} 
A Segunda forma de justiça informada pela autora é a de investigação histórica. Esta forma de justiça parte da premissa de que examinar o passado é necessário para restaurar o coletivo em tempos de transição. Nesse ponto a autora trata da produção da história através de julgamentos que, aparentam ser muito mais compatíveis com a produção ou investigação da história. Vale dizer que a investigação histórica e a narrativa desempenham papel importante na transição, ligando o passado ao presente e cabe, ainda, ressaltar que a verdade oficial que geralmente resulta da investigação, aparenta assumir um grau de consenso democrático que pode não ocorrer na prática, mas que, ainda assim, não diminui o potencial de contribuir para a justiça. A justiça histórica de transição realça a relação construtiva entre regimes da verdade e regimes políticos e pode ser alcançada através de "julgamentos", no mais das vezes realizados por Comissões de Verdade. Vale dizer que, os precedentes jurisprudenciais também se transformam em documentos históricos que revelam as injustiças cometidas pelo regime repressivo. A autora conclui que a investigação histórica contribui para a preservação da identidade política de um Estado e tem sido mais frequentemente de transição, do que de alicerce ou fundamento do futuro do $\operatorname{Estado}^{20}$.

As Políticas de reparação ou justiça reparatória têm sido as respostas mais comuns para fazer frente ao legado de crimes, independentemente da cultura política. Na obra, a autora discute a evolução das reparações nas relações internacionais, uma vez que foi algo atribuído ao Estado-nação, mas é cada vez mais direcionado para os indivíduos. De acordo com a autora, as reparações são uma forma de olhar e reparar o passado ao se compensar as vítimas e olhar o futuro de forma progressista, pois seria uma forma de promover a paz e a reconciliação. A autora apresenta como um dos principais desafios na concessão de indenizações, abordar os erros do passado e

\footnotetext{
${ }^{20}$ TEITEL, Ruti, G. Op. Cit, Pp. 117
} 
determinar quem é elegível. Outro dilema importante que ela traz é que, frequentemente, as gerações futuras são chamadas a prover a reparação ou uma ação afirmativa em relação às vítimas ${ }^{21}$.

Outra resposta comum para tentar alcançar a justiça depois de um legado de violações dos direitos humanos são as medidas administrativas ou justiça administrativa. A justiça administrativa e o uso do Direito Público para redefinir os parâmetros de qualidade de membro político, participação e liderança que constituem a comunidade política, também representam um modelo de justiça de transição. Medidas administrativas representam um desafio para a construção do Estado Democrático de Direito. A justiça administrativa ilumina o potencial distintivo do Direito para reestruturar a relação entre o indivíduo e a comunidade política em transição. Tais medidas de Direito Público definem novas condições limítrofes em uma base política explícita. Através da justiça administrativa, o Direito Público é utilizado para responder ao regime passado, e também para remodelar a ordem política sucessora. Mas as medidas administrativas de transição, também apresentam certas dificuldades, na medida em que para nivelar as condições políticas sobre os indivíduos com base no comportamento passado, em grande parte se suprime o potencial das recém-criadas instituições políticas. Existe um desejo de proteger a democracia florescente, mas estas medidas podem ser iliberais ${ }^{22}$.

Por fim, a autora trata do papel das Constituições em tempos de transição, ou de justiça constitucional. A autora considera que as Constituições têm uma relação de reciprocidade, na medida em que dão forma à transição e são moldadas por ela. Nas transições, as Constituições são muitas vezes vistas como provisórias e não

\footnotetext{
${ }^{21}$ Ibidem.

${ }^{22}$ Ibidem.
} 
permanentes, de modo que não são consideradas necessariamente como base fundante voltada para o futuro. Para a autora, a justiça constitucional cumpre os propósitos do constitucionalismo constitutivo convencional, mas também cumpre propósitos transformativos. De acordo com a mesma, enquanto as instituições são concebidas como fundadoras voltados para o futuro; em períodos de mudanças políticas radicais, Constituições são ao invés, textos mediadores, simultaneamente voltados para o passado e o futuro, compreendendo modalidades constitucionais e graus de incorporação variáveis $^{23}$. Vale frisar que as diferentes concepções de justiça de transição acima apresentadas não esgotam as "modalidades" possíveis de justiça de transição nem o uso de uma implica na exclusão das outras. Estas modalidades procuram lidar com questões intrínsecas ao papel do direito na transição política radical, na medida em que este deve garantir não apenas a justiça, mas também a ordem e a reconciliação.

De acordo com Lydiah Kemunto Bosire ${ }^{24}$, As medidas de justiça transicional podem estar intimamente relacionadas e se influenciar mutuamente, resultando de tal situação a idéia de poderem ser aplicadas simultâneamente, dependendo do caso. Neste ponto, vale dizer que, apesar da exigência de padrão mínimo, o conceito de justiça de transição é de certa forma fluído e abrangete e as suas modalidades e seu ponto de implementação, muito particular, variando caso a caso . A autora exemplifica afirmando que, provas colhidas a partir de processos de busca da verdade podem ser usadas para apoiar processos e determinar beneficiários em programas de reparação, relacionando dessa forma a justiça histórica à justiça reparatória. Como ensina Ruti Teitel, ao longo dos anos, iniciativas de justiça transicional vêm exibindo prioridades diferentes.

\footnotetext{
${ }^{23}$ TEITEL, Ruti, G. Op. Cit, Pág. 191.

${ }^{24}$ BOSIRE, Lydiah Kemunto, Grandes promessas, pequenas realizações: justiça transicional na África subsaariana, Revista internacional de direitos humanos: SUR, São Paulo, v. 3, n. 5, p. 74, 2006. Disponível http://bdjur.stj.gov.br/xmlui/bitstream/handle/2011/22642/grandes_promessas_pequenas_realizacoes.pdf? sequence=1 Acesso em: 20/05/2011.
} 


\subsubsection{Mecanismos de busca da verdade}

De entre as medidas que podem ser aplicadas no âmbito da justiça de transição se encontram as mecanismos de busca da verdade. Estes, inerentes à justiça de transição, tentam satisfazer o direito das vítimas à verdade e dar à comunidade a versão mais completa possível dos fatos. Embora não seja possível processar todos os perpetradores devido aos muitos desafios identificados acima, instituições como as comissões de verdade são frequentemente estabelecidas para ajudar a reparar o período de impunidade. De acordo com Lydiah Kemunto Bosire ${ }^{25}$, de entre os mecanismos possíveis de busca da verdade tem-se as comissões de verdade, os programas de reparação e o Vetting.

As Comissões de verdade, nas palavras de Tzvetan Todorov ${ }^{26}$, são um meio de educação coletiva próximo da justiça, mas melhor preparados que ela, pois renunciam à punição, partindo do postulado de que o advento da verdade terá um valor educativo maior que algumas sanções individuais. Finalmente essas comissões produzem um trabalho que coloca a sociedade inteira diante de suas responsabilidades, em vez de lhe conceder a comodidade que consiste em designar alguns bodes expiatórios.

As Comissões de verdade são mecanismos encarregados de investigar e revelar os graves abusos e violações de direitos humanos ocorridos no passado, cometidos pelo Estado ou com a conivência deste, ou ainda pela omissão deste. O foco está em

\footnotetext{
${ }^{25}$ BOSIRE, Lydiah Kemunto, Op. Cit., Pág. 79.

${ }^{26}$ TODOROV, Tzvetan, Os limites da justiça, In CASSESSE, Antonio e DELMAS-MARTY, Mireille (org.), Crimes internacionais e jurisdições internacionais, São Paulo, Manole, 2004, Pág. 42.
} 
determinar o que aconteceu e apontar os responsáveis ${ }^{27}$. As comissões podem ter papel investigativo, judicial e educativo e podem alcançar a restauração de valores em uma sociedade em transição, influenciando a reconstrução da identidade nacional. São instauradas com o abjetivo de promover justiça restaurativa e pôr um fim no conflito com o passado. As comissões trazem a inovação de serem centradas na vítima ao invés do réu, e tem por ponto principal, a par da idéia de justiça, a criação de um clima de confiança na sociedade no futuro. Já os programas de reparação, de acordo com Lydiah Kemunto Bosire ${ }^{28}$, atendem pelo menos a três objetivos: reconhecer as vítimas como cidadãos detentores de direitos específicos, comunicar uma mensagem de que a violação desses direitos merece uma ação por parte do Estado; contribuir para estabelecer confiança cívica entre os cidadãos e entre estes e as instituições do Estado; e construir solidariedade social à medida que a sociedade demonstra empatia com as vítimas. Ainda de acordo com a autora acima citada ${ }^{29}$, definido como um "processo formal para a identificação e remoção do serviço público de indivíduos responsáveis por abusos”, o vetting está se tornando parte integral do processo de restauração de confiança nos órgãos estatais, numa tentativa de assegurar que as estruturas que facilitaram abusos de direitos humanos no passado não venham a existir mais. Ou seja, os processos de vetting destinam-se à triagem funcionários para determinar se a sua conduta anterior (incluindo, o mais importante do ponto de vista da justiça transicional, o seu respeito por normas de direitos humanos) garante a sua não-exclusão de instituições públicas, isso especialmente para oficiais de polícia, funcionários de serviços prisionais, membros do exército e do judiciário ${ }^{30}$.

\footnotetext{
27 ROTBERG, Robert Irwin, Truth comissions and the provision of truth, justice and reconciliation, Princeton, 2000, Pág. 33.

${ }^{28}$ BOSIRE, Lydiah Kemunto, Op. Cit., Pág. 83.

${ }^{29}$ Ibidem.

${ }^{30}$ MAYER-RIECKH, Alexander, GREIFF, Pablo de, Justice as prevention-Vetting public employees in transitional societies, ICTJ, 2007.
} 


\subsubsection{Fases da justiça de transição}

De acordo com a autora, as origens da justiça transicional podem ser traçadas a partir da I Guerra Mundial, mas se torna compreendida como extraordinária e internacional no período pós-guerra depois de 1945. A autora divide, então, a genealogia da justiça de transição em três fases ${ }^{31}$.

Ruti Teitel apresenta ou propõe uma genealogia que traça a busca histórica por justiça em periodos de fluxo /corrente/mudança politica, revendo os desenvolvimentos politicos da última metade de século e analisando a evolução da concepção de justiça transicional. A autora afirma que a genealogia da justiça de transição demonstra, ao longo do tempo, estreitas relações entre o tipo de justiça buscado e as condições politicas limitantes. A genealogia proposta é estrutura através de ciclos críticos divididos em três fases, a saber:

A "Fase I" da justiça transicional diz respeito ao período pós-Segunda Guerra Mundial, e tem por símbolo os julgamentos de Nuremberg. O foco da justiça transicional era a criminalização internacional e os subsequentes processos criminais.

A "Fase II" diz respeito ao período pós Guerra-Fria está associada ao período de acelerada democratização e fragmentação politica que abrange as transições ocorridas após o declínio da União Soviética. Os conceitos de justiça locais e politizados, associados com a construção do Estado, foram implementados. A justiça foi além dos processos e incluiu mecanismos pouco explorados, como as comissões de verdade, reparações.

\footnotetext{
${ }^{31}$ TEITEL, Ruti, G. Transitional Justice Genealogy, Harvard Human Rights Journal, Vol.16, N.69, 2003, Pág. 70.
} 
A "Fase III" a autora denomina como, justiça transicional do Estado estável. Tem por símbolo a criação do Tribunal Criminal Internacional para a antiga Iugoslávia (ICTY) em 1993 e se caracteriza pela normalização da justiça transicional, que toma forma como a expansão da lei da guerra, como ilustrado pelo crescimento do Direito humanitário. Nesta fase, se faz menção à criação do TPI como uma corte permanente para processos de genocídio, crimes de guerra e crimes contra a humanidade. Estas três fases representam a evolução da idéia e prática da justiça de transição, apartir da criação do conceito e se referem a períodos históricos específicos. Pode-se perceber que ao longo do tempo ocorreu uma evolução do conceito e do campo de abrangência da justiça de transição. Primeiro verifica-se a criação e uso de sistema punitivo-judicial internacional para julgar e ao mesmo tempo criar um clima de justiça, como forma de evitar a perpetração de crimes bárbaros. E posteriormente um aumento considerável de instrumentos de direito internacional a lidar com o assunto. Vale dizer que para Teitel ${ }^{32}$, a criação do Tribunal Penal Internacional é o sinal da chegada a uma fase estável de desenvolvimento da justiça de transição.

\subsection{O Elemento "justiça" na justiça de transição}

\subsubsection{Papel do Direito em períodos de transição}

Ao tratar do papel do direito em períodos de transição, Ruti Teitel ensina que a lei, nesses termos, não é mero produto, pois é moldada pelas circunstâncias políticas ao mesmo tempo em que ela mesma pode estruturar a transição. Na mesma senda segue Cecília MacDowell Santos ${ }^{33}$ que afirma que em períodos de transição o Direito reveste-

\footnotetext{
${ }^{32}$ TEITEL, Ruti, Op. Cit, Pag. 90.

${ }^{33}$ SANTOS, Cecília MacDowell. A justiça ao serviço da memória: mobilização jurídica transnacional, direitos humanos e memória da ditadura. In TELES, Edson; TELES, Janaína de Almeida (Org.). Desarquivando a ditadura: memória e justiça no Brasil. v.2. São Paulo: Hucitec, 2009. Pág. 476.
} 
se de características excepcionais, sendo tanto prospectivo quanto retrospectivo, contínuo e descontínuo, e vai além das suas funções habituais, interligando-se à política em um esforço construtivo, contribuindo, sobremaneira, para a transformação radical da comunidade política.

Teitel argumenta, ainda, que a lei tem um papel constitutivo em tempos de grandes mudanças políticas, pois é alternadamente, constituída pela transição e constitutiva da transição. Como demonstra a autora, a lei anterior, muitas vezes dá forma às possibilidades disponíveis e apesar de muitos verem o Judiciário como um obstáculo à justiça, como cúmplice de crimes do passado, este tem também muitas vezes o importante papel de ajudar a romper com o passado através da realização de revisão judicial e abertura de vias de participação.

\subsection{Questões que afetam a justiça transicional}

De entre os vários problemas que podem afetar ou produzir impacto direto nos mecanismos de justiça, Lydiah Kemunto Bosire ${ }^{34}$ aponta as definições de "vítima" e "perpetrador," o uso de anistias, a elaboração de programas de programas de desmobilização, desarmamento e reintegração e o significado de reconciliação.

No que concerne aos programas de desmobilização, desarmamento e reintegração, a autora acima citada afirma que estes são cruciais para a segurança de qualquer situação pós-conflito, já que podem afetar a segurança onde outras medidas de justiça transicional estão para ser implantadas, assim como a disposição das vítimas e testemunhas em colaborar com qualquer desses processos. A segurança, por sua vez, pode aumentar ou diminuir a disposição do governo de assumir riscos pelo estabelecimento de medidas de responsabilização. A autora utiliza como exemplo as

\footnotetext{
${ }^{34}$ BOSIRE, Lydiah Kemunto, Op, cit., Pág. 85.
} 
transições africanas onde, de acordo com a mesma, pelo menos 7 das 12 transições da África subsaariana vieram após violento conflito, com grande número de combatentes e durante a transição, os ex-combatentes deveriam ser reabilitados e receber incentivos adequados para se reintegrarem à vida civil. No que dia respeito às anistias a autora firma que o uso amplamente disseminado da anistia nega às vítimas o direito de reparação, o que pode aumentar a urgência, ou a necessidade de outras medidas de justiça transicional. Igualmente comum é não processar, mesmo sem promessas formais de anistia. As justificativas são variadas: os julgamentos podem provocar violentas reações em situações em que a militarização ainda é forte; as provas necessárias podem ser escassas ou indisponíveis; a capacidade do novo Estado de investigar e processar pode ser reduzida por lealdades ao regime anterior; e os custos dos processos podem ser elevados. Ainda de acordo com a autora, os tipos de crime que as estratégias de justiça transicional visam atender é que usualmente definem os parâmetros de quem é classificado como "vítima" e "perpetrador" ${ }^{\text {"3 }}$. Perpetradores podem ter diferentes graus de responsabilidade na orquestração, perpetração ou no apoio a abusos de direitos humanos. Existem diversas situações nas quais a definição de "perpetrador" não se encaixa totalmente, levando a categorias de indivíduos com um "status moral e legal ambíguo." Por exemplo, há casos em que malfeitores, ou indivíduos que se beneficiaram de crimes cometidos por outros mais tarde, resistem e lutam contra o regime repressor; há aqueles que primeiramente resistiram e combateram o regime e depois acabaram colaborando com ele; também há vítimas que, sob coação,

\footnotetext{
${ }^{35}$ A autora, Lydiah Kemunto Bosire, chama a atenção para estas definições, pois, de acordo com a mesma, na África do Sul, Uma "vítima" foi definida como o indivíduo (e, portanto sua família imediata) sobre quem "graves violações de direitos humanos" foram perpetradas, que podem ter resultado em "dano físico ou mental, sofrimento emocional, perda pecuniária ou substancial impedimento dos direitos humanos". Foi ainda considera que subjacente à perpetração teria que haver uma motivação política. Ao usar esta definição, o TRC ignorou a motivação política do sistema de apartheid, e efetivamente admitiu "apenas aquelas violações sofridas por ativistas políticos ou agentes do Estado", o que excluía comunidades inteiras que haviam sido vitimadas. Vale também dizer que outras categorias de pessoas que não são normalmente designadas como vítimas incluem as populações deslocadas internamente, que na região dos Grandes Lagos somaram mais de 10 milhões.
} 
colaboraram e facilitaram o trabalho de perpetradores; e assim por diante. A ambiguidade que cerca o conceito de "perpetrador" pode também se aplicar às vítimas. Muitos soldados-crianças envolvidos em abusos de direitos humanos na África foram abduzidos e forçados a cometer atrocidades (perpetradores também podem ser vítimas). Numa definição ampla, perpetradores e beneficiários de abusos de direitos humanos podem incluir instituições, e atores estatais e não estatais, mesmo que ultrapassem fronteiras nacionais ${ }^{36}$. Ampliar a definição de "perpetrador" pode ter implicações tanto para a demanda de reforma institucional como para a atribuição de reparações. Por exemplo, o Estado talvez não fique tão inclinado a pagar reparações quando os abusos podem ser diretamente atribuídos a outras partes. No que concerne à definição de reconciliação, Lydiah Kemunto Bosire ${ }^{37}$ afirma que entendida de diversas maneiras, Reconciliação, minimamente, é a condição sob a qual cidadãos podem confiar uns nos outros como cidadãos. Isso significa que eles estão suficientemente comprometidos com as normas e valores que motivaram suas instituições vigentes, suficientemente confiantes em que aqueles que operam estas instituições o fazem com base naquelas normas e valores, e suficientemente seguros a respeito do compromisso de seus concidadãos de se aterem a essas normas e valores básicos. A reconciliação, ainda nas palavras da autora é considerada por alguns como um pré-requisito, assim como um produto da democracia, desenvolvimento e respeito pela vigência da lei. Outros associam o termo a noções como curar, esquecer, perdoar, coexistir e desculpar, mas que envolve fundamentalmente o estabelecimento da verdade.

\footnotetext{
${ }^{36}$ A autora usa o exemplo da República Democrática do Congo e da Serra Leoa, onde, no primeiro caso, muitas empresas foram implicadas como fomentadoras de conflitos e de abusos de direitos humanos, mas não existe nenhuma maneira clara de tratar de suas infrações e no segundo, o da Serra Leoa, onde corporações que se envolvem de modo similar na exploração de recursos e continuam com seu trabalho com impunidade quase completa, apesar de ter concluído que o setor de diamantes incentivou a guerra.

${ }^{37}$ BOSIRE, Lydiah, Op. Cit. Pág. 90.
} 


\section{O PROCESSO DE TRANSIÇÃO GUINEENSE}

\subsection{O Continente africano}

Desde o inicio dos anos 1990, vários paises africanos subsaharianos têm tentado abordar abusos de Direitos Humanos ocorridos no passado. Até então, o continente tem sido marcado por ondas de violência e conflitos que têm contribuido significativamente para o aumento da pobreza, da exclusão e da instabilidade gerando um circulo vicioso de difícil término. A abordagem ou o enfrentamento do passado (por vezes recente) de abusos de direitos humanos, como forma de se evitar novos abusos e até de se construir um Estado de Direito tem sido realizada apoiando-se em uma mistura variada de mecanismos de justiça de transição como processos judiciais, busca da verdade, esforços de reconciliação, reparações ou reforma dos setores da justiça e segurança. No entanto, vários paises africanos enfrentam um desafio particular quando abordam o seu passado. Nem a independência, nem o final da Guerra Fria levaram mudanças democraticas efetivas, paz ou prosperidade. Ao contrário, a brutal dominação colonial foi seguida do autoritarismo pós independencia e mais recentemente a repressão à oposição e a movimentos da sociedade civil tem contribuido para a sucessão de legados de abusos massivos dos direitos humanos. Foi essa a experiência de países como Uganda, Etiópia, Eritreia e a própria Guiné-Bissau nos anos 1990, quando exmovimentos de libertação criaram sistemas de partido único que cometeram abusos de Direitos Humanos impunemente ${ }^{38}$.

\footnotetext{
${ }^{38}$ Conflict and Transitional Justice in Africa, ICTJ - International Center for Transitional Justice, 2009, Pág.01, Disponível em: http://ictj.org/publication/conflict-and-transitional-justice-africa
} 
Vale fazer menção ao fato de que a maior parte dos paises africanos que suportou conflitos domésticos ou regionais passa agora por algum tipo de transição política, mas que até então, alguns países como Burundi, a República Democrática do Congo, a Libéria, a Serra Leoa e o Sudão continuam sendo palco de conflitos tendo como alvo, civis desarmados $^{39}$. Isso porque, apesar dos esforços realizados no sentido de promover a paz e a reconciliação, algumas nações africanas têm questões de tal forma complexas e arraigadas que se tornam de dificil resolução.

O Caso de Ruanda é emblemático quando se fala em justiça de transição na África. Palco de conflitos sangrentos, de proporções drásticas, com a omissão da maioria da comunidade internacional, o país ainda sofre com as consequências dos horrores do genocídio. Em Ruanda, a maioria Hutu e a minoria Tusti têm uma identidade étnica socialmente construída. Embora se tratem de etnias diferentes, e tenham certas particularidades os grupos falam a mesma lingua, partilham os mesmos costumes, praticam a mesma religião, vivem juntos e até se casam entre si. Foi apartir do colonialismo belga que tratou Hutus e Tutsis como raças diferentes, enxergando os Tutsis como racialmente superiores e favorecendo a elite Tutsi que governou o Reino précolonial que essa identidade foi se distorcendo. Em 1959, três anos antes da independência os belgas se posicionaram com os Hutus e ignoraram (perdoaram) a violência anti Tutsi que levou aproximadamente 400,000 Tutsis ao exilio. O regime Hutu do pós-Independência institucionalizou a discriminação anti tutsi e conduziu a períodicos de massacres contra tutsis em resposta a possiveis ameaças à sua posição no $\operatorname{poder}^{40}$.

\footnotetext{
${ }^{39}$ Conflict and Transitional Justice in Africa, Op. Cit., Pág. 01.

${ }^{40}$ WALDORF, Lars, Transitional Justice and DDR: The Case of Rwanda, Research Unit ICTJ, 2009, Pág. 05.
} 
A Frente Patriótica de Ruanda (Rwandan Patriotic Front - RPF), movimento rebelde dominado por Tutsis exilados em Uganda, invadiu Ruanda em outubro de 1990, desencadeando uma guerra civil que durou quase quatro anos. $\mathrm{O}$ movimento rebelde exigia a partilha do poder político e o direito ao retorno de todos os refugiados tutsis (quase um milhão de pessoas). Ao mesmo tempo o regime autoritário do Presidente Juvenal Habyarimana estava sob pressão da comunidade internacional e de oponentes nacionais Hutus para mudar o regime de partido único para a democracia multipartidária. Em resposta a estas ameaças políticas, Habyarimana e seus aliados militarizaram a sociedade ruandense, massacraram civis tutsis e implantaram o medo nos hutus alegando que os refugiados Tutsis os tirariam das suas terras, também demonizaram civis tutsis e a Oposição Democratica Hutu como aliada da Frente Patriótica de Ruanda.

Em julho de 1992, a Frente Patriótica de Ruanda e o governo Ruandês assinaram um cessar-fogo e um mês depois assinaram o primeiro de vários acordos de paz coletivamente conhecidos como Acordos de Paz de Arusha. Após uma série de massacres de civis tutsis, a Frente Patriótica de Ruanda violou o cessar-fogo em fevereiro de 1993 com um ataque em larga escala no noroeste de Ruanda que deslocou milhares de pessoas. As forças Armadas de Ruanda só conseguiram fazer frente ao avanço do grupo rebelde com apoio militar francês. Foram retomadas as conversações pela paz e o acordo final foi assinado em agosto de 1993, mas só após doadores internacionais ameaçarem Habyarimana com o corte total da assistência estrangeira. Os acordos de Arusha criaram um governo de transição de base alargada que deixaram Habyarimana no poder, mas partilhando-o com a oposição interna e a Frente Patriótica de Ruanda. Também foi demandada Missao de manutenção de paz das Nações Unidas, conhecida pelo acrônimo UNAMIR. No dia 06 de abril de 1994 assaltantes 
desconhecidos abateram o avião de Habyarimana, matando todos os que estavam a bordo. Hutus extremistas tomaram o controle da situação e lançaram uma campanha de exterminio contra os Tutsis. Incitaram o genocídio implantando estereotipos racistas dos Tutsis como "etíopes" que queriam reinstalar uma monarquia feudal e dispôr da maioria Hutu. Usando a mídia, também "pintaram" todos os civis Tutsis como a "Quinta Coluna" da Frente Patriótica de Ruanda. Em julho de 1994 pelo menos meio milhão de Tutsis bem como milhares de Hutus, foram mortos ${ }^{41}$.

É Dificil falar do caso de Ruanda, sem fazer menção ao conflito nos Grandes Lagos, uma vez que, mesmo não se confundindo se encontram interligados tanto pela proximidade geográfica, pelos constantes ataques de Ruanda, quanto pelo fato de partilharem grupos étnicos (Hutus e tutsis estão presentes nos paises que compõe os grandes lagos, a saber: Burundi, Uganda, República Democrática do Congo e Ruanda), o que está na origem dos conflitos na região. Um dos pivôs dos conflitos armados no congo é a nacionalidade. Ou seja, a identidade dos tutsis e o seu reconhecimento como cidadãos congoloses ${ }^{42}$.

O Estopim para o conflito nos Grandes Lagos se deu ao término do genocídio em Ruanda. O governo genocida voou para o Zaire levando consigo mais de um milhão de refugiados e usou os campos de refugiados no Zaire para lançar ataques a Ruanda. A comunidade internacional falhou em evacuar combatentes armados dos campos de refugio ou mover os campos para longe da fronteira Ruandesa.

O Então presidente do Zaire, Mobutu Sese Seko, que era próximo de Habyarimana, apoiou os Hutus de Ruanda. Em 1995 o governo do Zaire retirou aos Rwandophones (O

\footnotetext{
41 PRUNIER, Gérard, The Rwanda Crisis: History of a Genocide, New York, Columbia University Press, 1995, p. 390.

${ }^{42}$ WALDORF, Lars, Op. Cit. Pág.08.
} 
significado literal de "Rwandophone" é alguém que fala Kinyarwanda, a língua comum de hutus e tutsis em Ruanda, assim como em partes do leste da República Democrática do Congo e Uganda sul congoleses) a cidadania e em 1996 foram expulsos do país.

Tutsis congoleses pediram ajuda a Ruanda, que em outubro de 1996 invadiu o Zaire coligada com Uganda, Angola e os rebeldes liderados por Laurent Desire Kabila da Aliança das Forças Democraticas para a Libertação do Congo-Zaire.

A Coligação derrubou Mobutu em Maio de 1997 e colocou Kabila como presidente. Este, em 1998 se virou contra os seus patrocinadores de Ruanda e expulsou todos os soldados estrangeiros. Em resposta Ruanda novamente invade o Congo com a ajuda de Uganda e Burundi, em uma batalha pelo controle de Kisangani e do leste do Congo, rico em recursos naturais (ouro, diamantes, petróleo) mas desta vez Angola, Namíbia e Zimbabue se colocam do lado de Kinshasa. Estima-se que mais de três milhões de pessoas tenham falecido. Em agosto de 1999 foi assinado entre as partes beligerantes o Acordo de Paz de Lusaka. O acordo previa, entre outros pontos, a operação de manutenção da paz enviada pela ONU (MONUC). Foi acordado que todas as milicias seriam desarmadas e os suspeitos de genocidio seriam entregues ao Tribunal Penal Internacional para Ruanda (UNICTR).

Apesar das dificuldades em proteger os civis de ataques e por vezes destes servirem de escudo entre as fações beligerantes, com o apoio dos programas da UNAMIR, e de outros programas criados para o efeito, Ruanda conseguiu com sucesso demobilizar e reintegrar aproximadamente 54,000 combatentes desde 1995. A desmobilização parece ter reduzido o contingente do exército ruandês e o orçamento a este destinado.

Já no caso do Congo, os programas de desmobilização não têm sido tão bem sucedidos, na medida em que, menos de um terço dos rebeldes foi desarmado ou 
desmobilizado. As dificuldades de implementação de mecanismos de busca de paz são consideráveis. A MONUC, por exemplo, foi criada como missão de observação do acordo de paz, posteriormente foi transformada em missão militar autorizada a usar os meios necessários para desarmar, desmobilizar e reinserir os combatentes, mas não tem conseguido evitar as crises que têm confrontado o país ${ }^{43}$.

Desde o genocídio o governo de Ruanda tem tentado prover segurança e reconstruir o país, não obstante as enormes dificuldades econômicas e políticas. Apesar do compromisso declarado em promover a reconciliação, o governo tem-se tornado autoritário, prendendo e intimidando críticos, atacando a mídia independente e organizações da sociedade civil e fortalecendo sua posição no poder. O caso de Ruanda constitui um grande desafio à justiça de transição, dada a escala e a brutalidade do genocídio de 1994. Enquanto que vários outros países optaram por anistias ou investigação criminal, o governo de Ruanda tem buscado a responsabilização através de julgamentos criminais. Quando o número de suspeitos genocidas sobrecarregou as cortes nacionais, o governo lançou um sistema inovativo e ambicioso de 11,000 cortes comunitárias, denominadas gacaca, que envolveram boa parte da nação nos julgamentos. A justiça de transição em Ruanda tem se focado quase exclusivamente na responsabilização pelo genocídio de 1994, mostrando-se relutante em utilizar mecanismos não criminais como as comissões de verdade ou o vetting.

A Reforma institucional (principalmento do setor de segurança) não foi prioridade no pós genocídio, na medida em que a maioria daqueles associados com o governo, como a polícia e as forças armadas á epoca do genocídio fugiu do país e continua fora de Ruanda.

${ }^{43}$ BIZAWU, Sébastien Kiwonghi, O Conselho de Segurança da ONU e os conflitos nos Grandes Lagos:análise seletiva e interpretativa das resoluções sobre o Congo, Barueri, Manole Ed., 2008. Pág. 138. 
No que diz respeito ás reparações o governo ainda não estabeleceu o Compensation Fund for Victims of the Genocide and Crimes Against Humanity previsto na Lei do Genocídio de 1996 e nas Leis de Gacaca subsequentes. Este fundo deveria conceder compensações às vitimas sobreviventes do genocídio, mas devido às dificuldades econômicas ainda não foi possivel a concessão de reparações pecuniárias. Apesar da falta de compensações, as leis de Gacaca têm possibilitado restituições a sobreviventes que perderam terras. Aqueles que não podem pagar pelos bens que destruíram ou roubaram, realizam trabalho não remunerado em favor dos sobreviventes; aqueles que se declaram culpados devem revelar o paradeiro dos restos mortais das suas vítimas para se beneficiarem da redução das penas. Durante o genocídio muitas vítimas foram jogadas em latrinas e valas ou deixadas em encostas. $\mathrm{O}$ apelo dos sobreviventes do genocídio é que além das compensações se descobram os restos mortais dos que lhes são caros, de forma a enterrá-los com dignidade.

No que concerne aos processos judiciais, O Tribunal Penal Internacional Para Ruanda (TPIR) apreendeu e conseguiu afastar grande parte das lideranças políticas e militares consideradas envolvidas no genocídio, dessa forma removendo uma potencial força desestabilizadora na região. Tal foi possivel com o programa Rewards for Justice dos Estados Unidos, que ofereceu 05 (cinco) milhões de dólares por informação que levasse à captura de altos suspeitos de genocídio. Este programa em consonância com a pressão diplomática sobre Kinshasa estimulou a captura e transferência do ex-chefe das FAR, o general Augustin Bizimungu para o Tribunal Penal Internacional para Ruanda.

Vale dizer que o Tribunal Penal Internacional para Ruanda foi criado pelo Conselho de Segurança da ONU através da resolução 955 de 08 de novembro de 1994 e tem sede em Arusha, na Tanzânia. Foi estabelecido como forma de contribuir para o processo de 
reconciliação nacional, para o julgamento dos responsáveis pelas graves violações a Direitos Humanos cometidas no país e de forma a evitar futuros conflitos ${ }^{44}$.

Entre as pessoas denunciadas e julgadas no Tribunal Penal Internacional para Ruanda entre 2009 e 2011 encontram-se Augustin Bizimungu, Callixte Kalimanzira, Gaspard Kanyarukiga, Callixte Kalimanzira, O coronel Theoneste Bagosora e outros dois generais, Aloys Ntabakuze e Anatole Nsengiyumva.

A grande contribuição desse Tribunal foi a definição do crime de genocídio, especificado em dois sentidos: 1) o ato criminal foi realizado com a intenção de destruir um grupo nacional, étnico, racial ou religioso, embora possa ser cometido até contra um só indivíduo; 2) a lesão grave à integridade física ou mental dos membros de um grupo e a violência sexual contra as mulheres, realizadas sempre com a mesma intenção ${ }^{45}$.

Já o caso da África do Sul, também emblemático na história de transição do continente, é o que apresentou mais sucesso, servindo de exemplo em várias partes do globo. O conflito na África do Sul remonta à chegada dos colonizadores europeus em $1652^{46}$. A expansão do território colonial levou a conflitos entre estes e as comunidades locais por quase dois séculos. A formalização do domínio branco se deu por meio da venda e expropriação de terras e pelo estabelecimento das colônias do Cabo e de Natal e da República Bôer nos anos de 1800. Em 1948, o National Party (NP) - representante da população afrikaner ${ }^{47}$ - sobe ao poder, implanta legalmente o apartheid ${ }^{48}$ e reforça as proibições contra a população negra.

\footnotetext{
44 AKHAVAN, Payam, The international criminal tribunal for rwanda, The American Journal of International Law, Vol. 90, N. 03, p. 504.

${ }^{45}$ MÓDULO DE PAULA, Luiz augusto, Genocídio e o Tribunal Penal Internacional para Ruanda, São Paulo, 2011, Pág. 04.

${ }^{46}$ MERWE, Hugo Van Der, LAMB, Guy, Transitional Justice and DDR: the case of South Africa, Research Unit ICTJ, 2009, Pág 05.

${ }^{47}$ Africandêr ou Bôeres são um grupo étnico sul-africano descendente de colonos caucasianos.
} 
Cresce a oposição ao apartheid, principalmente através do African National Congress $^{49}$ (ANC) e do Pan Africanist Congress ${ }^{50}$ (PAC). A relação entre as comunidades branca de negra nem sempre foi fácil, tendo ocorrido vários protestos não violentos, até 1961, quando, com o banimento do ANC, do PAC e de outros grupos libertadores se organizou uma força armada. Tal força armada funcionou entre os anos de 1960 e 1980 através de ataques de guerrilha contra militares e instalações do governo, ataques que foram repelidos pelas forças de segurança do governo que também reprimiam violentamente quaisquer manifestações contra o governo. $\mathrm{O}$ conflito também foi marcado pela violência entre os diferentes movimentos de libertação. Durante os anos 1980, as tensões entre o ANC e o Inkhatha Freedom Party (IFP) cresceram e tomaram proporções violentas, especialmente após as negociações de paz de 1989. Ambas as formações eram armadas, sendo o IFP suprido pelas forças de segurança do Estado. Nessa altura, os movimentos anti-apartheid se fortalecem e as Nações Unidas afirmam a condenação do regime do apartheid, declarando o Ano Internacional Anti-Apartheid em 1978. A transição para a democracia na África do Sul foi um processo longo e doloroso de negociações bilaterais e multipartidárias entre 1990 e 1994. Várias conversações bilaterais, principalmente entre o National Party, que como acima mencionado, institucionalizou o apartheid em 1948 e o ANC, que era o maior

\footnotetext{
${ }^{48}$ Apartheid foi um terrível sistema de segregação racial, implantado oficialmente pelo governo sulafricano de 1948 a 1994.

${ }^{49}$ O ANC ou African National Congress é um partido sul-africano fundado inicialmente como o South African Native National Congress (SANNC) em 08 de Janeiro de 1912 em Bloemfontein, com o objetivo de lutar pelos direitos dos negros sul-africanos. A organização foi rebatizada como ANC em 1923, após um período inércia política em razão das disputas de poder e falta de recursos. A crescente repressão, a aversão por negros e a brutal repressão de ativistas, por parte do regime apartheid, levou novamente à ativação do ANC, que em 1961 criou uma ala militar denominada Umkhonto we Sizwe (Lança da Nação / MK) em 1961. Através da MK, o ANC obteve o apoio de alguns países africanos e do bloco soviético para as suas actividades. Com o aumento da pressão interna e internacional, o governo do Apartheid foi forçado a entrar em negociações com o ANC. Este viu o colapso do Apartheid e o ingresso do regime democrático em 1994.

${ }^{50}$ O PAC ou Pan africanist Congress foi um movimento de libertação sul-africano lançado formalmente em 1959 em Soweto como um desdobramento do Congresso Nacional Africano. Foi proibido em 1960, após o massacre de Sharpeville, mas continuou a sua oposição armada ao governo Sul-Africano, até que foi legalizado em 1990.
} 
grupo de libertação, serviram de base para o estabelecimento de negociações multipartidárias sobre o futuro do país. As conversações iniciais eram focadas no término da violência política, na libertação de prisioneiros políticos e na formação de um governo interino.

Após a libertação de Nelson Mandela em fevereiro de 1990 e a legalização de numerosos partidos políticos, as conversações levaram a acordos sobre processos que libertariam certos prisioneiros políticos e assegurariam que exilados políticos não fossem presos quando retornassem ao país. Este acordo, denominado Groote Schuur Minute, levou à promulgação do Indemnity Act de 1990, que deu anistia temporária a membros do ANC acusados de violência política. Estas negociações levaram ao estabelecimento do Acordo Nacional de Paz em 1991 que delineou um quadro que lidaria com protestos políticos e conflitos comunitários. Também estabeleceu medidas de resolução de disputas de forma a abordar o alto nível de contínua violência política. Estas medidas foram consideradas importantes, dado o crescente nível de violência que culminou com o massacre de Boipatong em 1992, que parou as conversações. O ANC culpava o governo de não ter protegido as comunidades a ele alinhadas e de cumplicidade no massacre.

Quando as negociações começaram, estavam centradas na criação de uma Contituição interina. Finalmente, em dezembro de 1993 se conseguiu acordar pela Contituição interina e pela realização de eleições para o parlamento. Conservadores brancos da direita ainda tentaram minar o processo de eleições, mas não conseguiram. Não obstante terem-se verificado alguns ataques, as eleições de 1994 foram pacíficas e aceites internacionalmente como justas e livres. A Constituição foi aceite pela generalidade das forças políticas e pela sociedade sul-africana e saudada como uma grande vitória pelos defensores dos direitos humanos, na medida em que previa uma 
forte cartela de direitos, instituía a independência do poder judicial e outras garantias de boa governação. É importante ressaltar que incluída, também, direitos socioeconômicos, considerados elemento chave no contexto de um país que enfrentava vasta pobreza e desigualdade. A sociedade civil teve papel importante no processo de paz e nas negociações constitucionais. Durante o processo de paz, várias ONGs foram chamadas a ajudar na implementação das estruturas dos acordos de paz, na monitoração da violência e abusos e levá-los a público e na redação da Constituição.

Faltava a criação de mecanismos que fizessem justiça aos graves abusos de direitos humanos. Com a abertura política, o país confrontou-se com um imenso passivo de crimes e desrespeitos aos direitos humanos no período anterior, que prosseguiam ou se agravavam na fase de transição. Esses crimes e abusos foram cometidos, como acima mencionado, não somente pelos aparelhos de repressão do estado sobre os opositores e a população não-branca em geral, mas ocorreram também entre grupos rivais na luta contra o sistema. Havia também que discutir a natureza das ações dos que lutaram para a libertação e determinar se algumas delas também seriam comináveis como crimes. Além da delicada negociação que permitiu a transição democrática, a qual envolveu a discussão de fórmulas consociativas para assegurar alguma parcela de poder aos grupos que, com a franquia generalizada, tornar-se-iam minoritários na nova ordem, havia também a questão de como lidar com os agravos do passado ${ }^{51}$.

A Constituição interina de 1993 previa anistia para todos os combatentes envolvidos na violência política. Ao invés de anistia geral, o novo governo da ANC optou por uma anistia provisória ligada a um processo de verdade e reconciliação. A promulgação da anistia foi, assim, incorporada no estabelecimento da Comissão da Verdade e Reconciliação. Uma das funções da Comissão era implementar a obrigação

\footnotetext{
${ }^{51}$ CINTRA, Antônio, As Comissões de verdade na África do Sul, 2001. Pág. 02.
} 
constitucional de conceder anistia, pressão exercida pelo NP que queria se assegurar que seus membros não se tornassem vítimas de um novo governo.

Foi adicionada, à acima mencionada Constituição, uma secção de Promoção da Unidade Nacional e Reconciliação que estabelecia a forma como se iria lidar com a anistia. Esta disposição deu lugar à Lei de Promoção da Unidade Nacional e da Reconciliação n 34 de 1995, que estabelecia que a referida Comissão teria os seguintes objectivos:

(i). Estabelecer um quadro completo das violações graves de direitos humanos de Março de 1960 a Maio de 1994; facilitar a atribuição de anistia aos que revelassem totalmente os factos na condição de estarem associados a objetivos políticos;

(ii). Restaurar a dignidade civil às vítimas;

(iii). Recomendar as medidas de reparação e prevenção de futuras violações, compilando toda a informação num relatório final ${ }^{52}$.

A Comissão era composta por três comitês: o Comitê para as Violações de Direitos Humanos, o Comitê para a Anistia e o Comitê para a Indenização e Reabilitação. De forma a conferir legitimidade à Comissão, a lista de candidatos a comissários foi organizada por um comitê multiracial e políticamente diverso, sob a presidência do Arcebispo Desmond Tutu.

A Comissão de Verdade e Reconciliação começou as suas primeiras audiências em East London, em $1996^{53}$. As audiências das vítimas terminaram em 1998, quando foi entregue o Relatório Final ao presidente Mandela. O Comitê para a Anistia apenas

\footnotetext{
${ }^{52}$ MARQUES, Ângela, O Processo de reconciliação na África do Sul, Centro de Investigação e Análise em Relações Internacionais, Pág. 10.

${ }^{53}$ Ibidem.
} 
terminou as audiências em Maio de 2001, encerrando formalmente o trabalho da Comissão.

A função de busca da verdade da Comissão foi realizada através de uma série de mecanismos. Houve um processo muito complexo de tomada de declarações, que envolveu centenas de entrevistadores visitando inúmeras comunidades e a coleta de depoimentos de mais de 22.000 vítimas. Estas declarações foram, então, seguidas de investigações para a verificação dos fatos. A Comissão também iniciou investigações e pesquisas realizadas em "Window cases". Essas investigações procuravam examinar determinados tipos de crimes, ou incidentes específicos que forneceriam visões sobre padrões mais amplos de eventos. Finalmente, a Comissão também realizou investigações com relação a pedidos de anistia.

A maior crítica à Comissão foi que não desenvolveu um sistema de integração de suas diversas fontes de informações, contribuiu para tal, o fato de o Comitê de Anistia não se ter aproximado de forma a realizar um processo de investigação sistemática. Seus membros viram o seu papel como simplesmente verificar se o candidato estava falando a verdade em um caso particular. Não houve a coleta de informações sobre a história dos candidatos militares e não se fizeram perguntas-chave sobre a linha de comando, ou outras informações que podessem levar a uma compreensão mais sistemática dos abusos.

Como dito por Simone Pinto ${ }^{54}$, a África do Sul deu o exemplo de que as sociedades devem prevenir-se da recorrência das atrocidades passadas afastando-se do efeito corrosivo da mágoa e da vingança. As Comissões de Verdade surgem, nesses termos, como uma tentativa de revelar os fatos e de tratar, em um nível mais profundo, a

\footnotetext{
54 PINTO, Simone Martins Rodrigues, Justiça transicional na África do Sul: restaurando o passado, construindo o futuro, Contexto Internacional, vol.29 no.2, Rio de Janeiro, 2007.
} 
ferida social em sociedades que emergem de governos totalitários ou de guerras que deixam um rastro de opressão e mentira. A Comissão de Verdade e Reconciliação da África do Sul serve como exemplo principal de publicidade e transparência, na medida em que foram ouvidos testemunhos em público, que foram amplamente publicitados. A mesma autora aponta que uma novidade no relatório da Comissão de Verdade e Reconciliação da África do Sul foi a afirmação de que a linguagem ideológica é um dos principais fatores que contribuíram para as violações dos direitos humanos. Dessa forma, uma nova linguagem tem de ser estabelecida como instrumento de paz e unidade no país.

Muitos países já haviam utilizado a experiência das Comissões de Verdade, no entanto a da África do Sul foi única em sua contingência legal e social. Seu mandato era abrangente e ambicioso. O confronto com o passado foi largamente noticiado pela mídia e as audiências públicas foram acompanhadas em todo o país. Vítimas, violadores ou os omissos, todos foram envolvidos. A Comissão de Verdade encorajou todos os sulafricanos a refletirem sobre os abusos que cometeram, ainda que estivessem fora da jurisdição da Comissão, que foi criada para tratar somente das graves violações aos direitos humanos como assassinatos, estupros e tortura. A Comissão criou ainda um órgão próprio para receber reflexões pessoais de quem desejasse enviar declarações reconhecendo sua responsabilidade direta ou indireta pela opressão do apartheid.

Como dito anteriormente, após períodos de conflitos intensos, nações africanas dilaceradas pela guerra têm escolhido diversos métodos para lidar com o passado ${ }^{55}$. Nesses termos, mecanismos de justiça de transição como, pedidos de processos, busca da verdade, reparações e reforma institucional são cada vez mais comuns nos países que

\footnotetext{
55 GRAYBILL, Lyn S. Pardon, Punishment, and Amnesia: Three African Post-Conflict, Third World Quarterly, Vol. 25, No. 6 (2004), pp. 1117.
} 
se dispõem a enfrentar abusos cometidos contra os direitos humanos, na medida em que se argumenta serem essas abordagens necessárias para combater a impunidade e promover a reconciliação.

De acordo com Lydiah Kemunto Bosire ${ }^{56}$, atualmente, pelo menos doze países da África Subsaariana vivem algum estágio da implementação de medidas de justiça transicional e ao contrário do que ocorreu em países como Chile e Argentina, onde as medidas de justiça transicional foram administradas após situações relativamente claras de mudança de regime, na maioria dos casos em exame na África essas medidas foram implementadas após transições negociadas, sem uma ruptura clara com os conflitos passados e/ou presentes ${ }^{57}$. Nesses termos a autora acima citada coloca questões de suma importância ao entendimento de presente trabalho e que irão permeá-lo quando se for discutir o caso da Guiné-Bissau.

O que constitui uma "transição" na África? Será que a transição é marcada simplesmente pela decisão política de usar a retórica da justiça e da reconciliação, mesmo num contexto de ruptura mínima com o passado, talvez a fim de "criar a possibilidade democrática de re-imaginar os caminhos e metas específicos da democratização"? Pode um país ter uma sucessão de transições e aplicar medidas de justiça transicional a cada nova transição? São essas medidas adequadas mesmo em contextos de Estados precariamente institucionalizados, sem um histórico de tradição

\footnotetext{
${ }^{56}$ BOSERI, Lydiah Kemunto, Grandes promessas, pequenas realizações: justiça transicional na África subsaariana, Revista internacional de direitos humanos : SUR São Paulo, v. 3, n. 5, p. 70-109, 2 sem. 2006.

${ }^{57}$ Como exemplificado pela autora citada, O Acordo Lomé de 1999 para Serra Leoa foi o terceiro acordo de paz feito com o objetivo de encerrar o conflito e estabelecer a democracia. De modo similar, a Comissão Nacional de Reconciliação de Gana (NRC) foi a última na sucessão de medidas de responsabilização implementadas por vários governos a partir do golpe de Estado que depôs Kwame Nkrumah em 1966. A República Democrática do Congo e Uganda vivem atualmente diferentes graus de conflito, e estão em processo de implementar várias medidas de justiça transicional.
} 
democrática no estilo ocidental? Ou é possível que novos governos adotem a agora linguagem comum da justiça transicional para pleitear recursos num nível internacional?

O objetivo principal é que, ainda que ao longo do trabalho não se ofereçam respostas incontornáveis, se possa identificar a existência de uma verdadeira transição, a concepção transicional, a existência de instituições adequadas à realização da transição e a influencia da comunidade e das normas internacionais em tal processo.

Vale dizer que, apesar da falta de clareza a respeito de quando implementar a justiça transicional e de saber se o Estado possui instituições adequadas para tal implementação, os Estados têm obrigação de combater a impunidade e dar às vítimas uma reparação eficaz. Embora, no caso africano, países como Uganda e República Democrática do Congo, tenham tomado diversas medidas de justiça transicional aparentemente para cumprir com essa obrigação, a impunidade continua amplamente disseminada já que a implementação dessas medidas enfrenta vários obstáculos ${ }^{58}$.

À priori o caso da maioria dos Estados africanos parece oferecer explicações preliminares possíveis: a fraqueza das Instituições dos Estados, que faria com que as medidas transicionais não oferecesse os resultados pretendidos, como o combate à impunidade ou a promoção da reconciliação; a falta de certos pressupostos implícitos necessários à implementação e consecução da justiça de transição, como um Estado legítimo e coerente, uma sociedade civil independente e cidadãos com representação política; o fato de muitos dos conflitos que precederam a transição não estarem claramente delimitados por fronteiras, um dos impactos das fronteiras porosas é que as

\footnotetext{
${ }^{58}$ BOSIRE, Lydiah Kemunto, Op. Cit. Pág. 86. A autora explica que em muitos casos os processos domésticos não são nem sistemáticos nem movidos no momento certo, em parte devido à precária capacidade judicial. A busca de verdade e as medidas de reparação, frequentemente implementadas em contextos de conciliação política e de recursos limitados, podem parecer com falta de boa-fé. Na quase ausência de julgamentos e reparações, muitas vítimas são deixadas sem atendimento, particularmente porque os esforços de coibir os responsáveis por abusos aos direitos humanos continuam a ser lentos e irregulares, e os perpetradores continuam ocupando posições de poder.
} 
medidas nacionais de combate à impunidade são com frequência incompletas. Além disso, a pobreza e/ou a distribuição desigual da renda e recursos têm sido frequentemente apontadas como fatores contribuintes, assim como consequências, do conflito e da ditadura.

As medidas de justiça transicional podem procurar esclarecer, e têm um impacto nessas causas primárias da violência e do abuso. Além disso, as dimensões econômicas do conflito e da repressão podem ter consequências para a reivindicação de reparações e para as possibilidades de reconciliação. Finalmente, a maioria dos países têm estado em transição desde a década de 1990 até hoje, um período em que o campo dos direitos humanos se mostrou mais intervencionista, o que tem implicado numa significativa pressão internacional para implementar medidas que corrijam a impunidade. Mas a falta de vontade política e a fraqueza das instituições de Estado têm minado todos esses esforços.

Outro ponto ressaltado por Lydiah Kemunto Bosire ${ }^{59}$ é o de que as medidas de justiça transicional na África continuam a se revestir de altas expectativas, não obstante as realidades desanimadoras das deficiências institucionais, da precária liderança, da pobreza e da falta de diálogo entre o governo e o povo. Num patamar não muito diverso, mas até bastante semelhante ao da maioria dos países africanos acima mencionados, e do contexto acima explicitado se encontra a Guiné-Bissau. Sacudido por constantes crises, que culminaram com o conflito político-militar de 1998, e que ainda permeam a realidade do país, este tem lutado para fazer frente aos inúmeros obstáculos que se impõem à concretização da democracia e do Estado de Direito.

\footnotetext{
${ }^{59}$ BOSIRE, Lydiah Kemunto, Op. Cit. Pág. 90.
} 


\subsection{A Guiné-Bissau: entendendo a (eterna) transição guineense}

Do acima exposto e como explicado por Tcherno Djaló ${ }^{60}$, pode-se perceber que, a história contemporânea da Guiné-Bissau tem sido uma sucessão de atos de violência política e institucional, que marcaram e têm marcado a memória coletiva, influenciando de certa forma a sua cultura política. Independentemente das causas ou ideais defendidos por cada movimento político, é de constatar que as grandes rupturas políticas da Guiné se fizeram não na base negocial e de compromisso, mas de violência.

Vale mencionar que a luta de libertação nacional, em si, foi um ato de violência política. Cada movimento politico é depositário ou reivindica certa legitimidade. Se a legitimidade da luta de libertação anticolonialista é considerada por toda a literatura e pelo povo incontestável, as outras contestações que se seguiram não tiveram a mesma unanimidade.

Os sucessivos golpes e sublevações perpetrados sempre se tentaram justificar pelas violações dos direitos humanos (detenções sem processo, tortura, execuções sumárias) e repressão, mas nenhum dos momentos pós-conflito tentou verdadeiramente fazer frente ao passado de abusos ou sequer evitá-los posteriormente, gerando os intermináveis ciclos de violência.

Para Tcherno Djalo ${ }^{61}$, todas as grandes crises políticas da Guiné-Bissau, com exceção feita à luta pela libertação nacional, são geradas pela capacidade de seus atores de transformar a racionalidade individual numa ação coletiva.

\footnotetext{
${ }^{60}$ DJALÓ, Tcherno, Lições e legitimidade dos conflitos políticos na Guiné-Bissau, In Soronda, Revista de Estudos Guineenses, Edição Especial 7 de Junho, 2000, pág. 25.

${ }^{61}$ DJALÓ, Tcherno, Op. Cit.Pág. 26.
} 
O primeiro golpe de Estado de 1980 encontrou sua "legitimidade", na velha clivagem entre as elites pretas e mestiças na Guiné. Por causa da origem sociocultural e o acesso à educação de que puderam beneficiar os denominados cabo-verdianos, estes colaboraram com o poder colonial, se revelaram preciosos auxiliares e intermediários entre os autóctones e as autoridades coloniais na gestão da administração e na supervisão dos trabalhos forçados. Mas mesmo tendo os "mestiços" fornecido ao movimento libertador nacionalista os seus melhores quadros, este passado de colaborador com o poder colonial ressurgiu assim que a tutela da elite mestiça caboverdiana começou supostamente a dificultar o acesso dos "pretos" a altos cargos no governo. O fato é que, os antigos combatentes, comandados por João Bernardo vieira, que viria a perpetrar o golpe de Estado, se consideravam injustiçados perante o sistema que permitia que jovens cabo-verdianos recém-chegados de Portugal ou de Cabo Verde, sem legitimidade militar os comandassem. Vale mencionar, que o argumento de que os combatentes para a liberdade da pátria deveriam assumir cargos de chefia no governo ainda subsiste e em muitos casos tem "justificado" sublevações. Vale ainda ressaltar, como acima mencionado, que as elites cabo-verdianas tiveram acesso à educação que a maioria dos combatentes guineense não teve. Então, como anteriormente referido, o grupo liderado por João Bernardo Vieira, apoiado nessa clivagem entre "pretos" e "mestiços", como forma de envolver o povo, mas com vista unicamente a assumir o poder, perpetrou o golpe de Estado de 1980.

O levantamento militar de 07 de junho foi visto inicialmente como sendo uma guerra interna do PAIGC. Jean-François Bayart ${ }^{62}$ identifica neste levantamento uma

\footnotetext{
${ }^{62}$ BAYART, Jean-François, Laguerre en Afrique: deperissment ou formation de l'etat? Republique sudafricaine, Congo-Kinshasa, Guinée-Bissau, In Esprit, Paris, 1998, p55-73, Apud, DJALO Tcherno Lições e legitimidade dos conflitos políticos na Guiné-Bissau, In Soronda, Revista de Estudos Guineenses, Edição Especial 7 de Junho, 2000 pág. 29.
} 
nuance tribalista, baseada na frustação da etnia balanta face à governação de João Bernardo Vieira, pertencente à etnia papel.

Tal como a sublevação de 1980, o levantamento militar de 07 de junho teve por base a profunda crise econômica pela qual o país atravessava e as cisões no PAIGC, agravadas pela acusação de tráfico de armas para a região de Casamansa, e a pressão internacional pela investigação e punição dos responsáveis, principalmente por parte do Senegal. O então Brigadeiro Ansumane Mané foi publicamente acusado de liderar o tráfico de armas, o que deu início ao conflito militar. Note-se que no início o grupo de "rebeldes" era composto por um pequeno número de antigos combatentes experientes na guerra de guerrilha. O conflito tomou proporções drásticas e arrastou-se por onze meses após a intervenção estrangeira requisitada pelo então presidente João Bernardo Vieira. A chegada do corpo expedicionário das tropas do Senegal e da Guiné-Conakry desencadearam uma onda de nacionalismo e de patriotismo. Com o que se cogitou ser uma ameaça de forças estrangeiras, ocorreu uma adesão em massa da população ao grupo rebelde, agora movido por uma "causa". A partir de então, o que de início era considerado um epifenômeno, um barafustar de militares descontentes transformou-se num vasto movimento popular desencantado com o regime do então presidente.

Numa primeira análise pode-se perceber que o conflito de 07 de junho de certa forma reabilitou as forças armadas e os antigos combatentes que se consideravam marginalizados no regime anterior, mas que até então não tinham realizado nenhum conflito com características tão drásticas. Doravante conscientes da força que representam no seio da sociedade, os militares passaram a não reivindicar, mas a “exigir” os seus direitos sempre com base na violência. 
Vale também dizer que este conflito proporcionou uma mudança profunda na sociedade guineense em termos de relações sociais, estatuto social e aspirações políticas, na medida em que propulsionou ao poder um grupo de predominância Balanta que antes não havia demonstrado pretensões hegemônicas, em detrimento de uma maioria antes composta pela elite Luso-cristianizada mestiço-crioula.

No plano econômico os resultados foram catastróficos. Os tímidos esforços que se haviam realizado em prol do desenvolvimento foram aniquilados. Tcherno Djaló entende os conflitos ocorridos como uma forma de transformar a racionalidade individual numa ação coletiva. Ou seja, de acordo com o autor:

"uma forma de legitimar uma ação política violenta e inconstitucional cuja motivação reside em primeiro lugar numa dinâmica individual, assenta nos argumentos de justificação que transformam uma racionalidade individual numa ação coletiva, como antes mencionado. Para conseguir uma adesão popular, os mentores das contestações aproveitam o disfuncionamento do sistema e o descontentamento geral para brandir argumento-choque como sendo a principal razão do uso da força ${ }^{63}$ ".

Consta que o que está na base das sublevações mencionadas é sempre o descontentamento pessoal de um grupo com acesso a armas e reduzida estrutura politica.

Fafali Koudawo $^{64}$ divide a transição na Guiné-Bissau em 02 (duas) partes, ou pelo que chama de dupla transição. A primeira transição inicia-se em 1990/1991, momento em que eclodem exigências de abertura; terminando em Julho /Agosto de

\footnotetext{
${ }^{63}$ DJALÓ, Tcherno, Op. Cit. pág 30.

${ }^{64}$ KOUDAWO, Fafali, Cabo Verde e Guiné-Bissau: da Democracia Revolucionária à Democracia Liberal, Instituto nacional de estudos e pesquisa, 2001. Pág. 86.
} 
1994, meses das primeiras eleições. A segunda transição começa no final da guerra de 1998/1990 no momento em que o Presidente João Bernardo Vieira se retira.

A primeira transição se dá aquando do golpe de Estado, batizado como Movimento Reajustador 14 de novembro. Resultado de uma profunda crise, o golpe teve como causas as contradições entre guineenses e cabo-verdianos em relação ao projeto binacional almejado pelo PAIGC, mas mal aceite pelas populações dos dois países, pelas dificuldades nascidas da passagem da teoria de Estado revolucionário à prática administrativa, num contexto mal preparado.

Iniciada no período de 1990/91, a primeira transição é marcada pelas exigências internas de renovação do PAIGC (na altura, partido Único), e de abertura política. Durante o processo da primeira transição, as eleições de Julho de 1994 deram a vitória ao PAIGC. O autor ${ }^{65}$ afirma que a liberalização política na Guiné-Bissau teve uma evolução lenta, marcada por hesitações, bloqueios e muitos sobressaltos. Além disso, a manutenção do status quo no poder contribuiu para dotar este processo de traços aparentemente contraditórios, mas ancorados nas mesmas premissas: as expectativas frustradas. $\mathrm{O}$ autor considera que a contradição reside no que designa por processo simultaneamente percebido como acabado, mas à maneira de um parêntese aberto em 1991 e fechado em 1994; e inacabado devido às mudanças qualitativas profundas adiadas pela ausência de alternância, pela fraca vontade política de mudança dos vencedores das consultas eleitorais, e pela inércia de um sistema complexo. Ou seja, as percepções dos governantes e dos governados sobre todo o processo eram opostas. Para os governantes, o resultado das eleições realizadas eram legitimadores da continuidade; enquanto que para parte dos cidadãos $o$ resultado não era verdadeiramente

\footnotetext{
${ }^{65}$ KOUDAWO, Fafali, Op. Cit, pág. 87.
} 
representativo da vontade popular, pelo que a Matemática conduzia a uma falsa interpretação legal e, portanto, a uma falsa legitimidade.

Naquele equívoco reside, o que Fafali Koudawo ${ }^{66}$ designa por Democratura, conceito que explica como o paradoxo desta abertura política que desemboca numa nova clausura do poder instalou a ideia de uma crise difusa, mas durável, saída de uma democratização abortada. A personalidade dos atores no poder, os desvios das novas regras do jogo democrático, as deficiências do novo sistema pluralista, agravadas pela crise interna do partido no poder consolidaram a ideia de um recuo das conquistas da abertura política e da ascensão de um regime bastardo, a democratura, o híbrido de democracia e ditadura que proliferou a partir dos meados dos anos.

Relativamente à segunda transição iniciada após o conflito político-militar de 07 de junho de 1998 o autor considera que esta tem por causas as consequências do processo de indepência e todos os principais atos subsequentes a esta, a questão mal resolvida da desmobilização dos antigos combatentes da guerra de libertação, o crescente fosso entre uma categoria de antigos combatentes privilegiados próximos dos círculos do poder político e a grande maioria dos antigos combatentes proletarizados, que se consideravam abandonados por um sistema gerido pelos seus antigos companheiros de luta, a incompleta despartidarização das forças armadas, que na origem eram o braço armado do PAIGC, a incompleta conversão do PAIGC em partido civil deliberadamente liberto das suas antigas ligações institutcionais nas forças armadas nacionais, a dificil adaptação do antigo partido único, o PAIGC ao novo contexto pluralista, os entraves ao surgimento de um verdadeiro Estado de direito com um poder despersonalizado e instituições a funcionar nos estritos limites das suas competências, a prevalência da má governação com profundas deficiências da administração de Estado,

\footnotetext{
${ }^{66}$ KOUDAWO, Fafali, Op. Cit, pág 214.
} 
com ineficiência crônica na utilização dos recursos e permanente opacidade na gestão dos bens públicos. No seu período de latência, a crise que deu início a uma nova transição surge das revelações sobre a existência de tráfico de armas em beneficio do Movimento secessionista da região sul do Senegal o MFDC ${ }^{67}$ (Movimento das Forças Democráticas de Casamance). É suspenso o Chefe do Estado-Maior, o brigadeiro Ansumane Mané e as diligências instauradas para realizar um inquérito nas Forças Armadas são consideradas parciais, pelo que a Assembléia Nacional Popular (ANP), sob pressão dos grupos parlamentares da oposição cria a sua própria comissão de inquérito. Com o avanço dos trabalhos da comissão parlamentar, o país entra em uma instabilidade cada vez mais marcada, que acaba eclodindo no já referido conflito.

O momento que se seguiu ao término do conflito, com a caída do poder do Presidente João Vieira, marca a segunda transição, na medida em que, se caracterizou pelo crescimento da impopularidade e flagrante deslegitimação do poder legal, sendo assimilável à retirada da confiança popular ou não renovação da confiança política, e pelo fim, agora real, da dominação do partido único, com a eleição por maioria no parlamento, das que antes eram as forças da oposição.

Ainda como forma de entender o fenômeno da transição na Guiné-Bissau tem-se a abordagem de Roy van Der Dritf ${ }^{68}$, que chama atenção para a necessidade de se entender o fator democracia na realidade guineense. De acordo com autor acima citado, na Guiné-Bissau a população é mais ou menos "apartidária" que não influência de forma fundamental a política nacional, nem participa na "democracia". O nível de democracia raramente ultrapassa o dos "procedimentos democráticos", como as

\footnotetext{
${ }^{67}$ O MFDC é o movimento que visa tornar a região de Casamansa, um país independente do Senegal. O movimento, considerado rebelde, pelo governo do Senegal, tem realizado uma série de confrontos que tem resultado em várias mortes e refugiados.

${ }^{68}$ DRIFT, Roy Van Der, Democracy: legitimate warfare in Guinea-Bissau, In Soronda, Revista de Estudos Guineenses, Edição Especial 07 de Junho, 2000, pág.37.
} 
eleições, o que a torna em um sistema altamente manipulativo. Tal realidade, ainda de acordo com o mesmo autor, para as relações exteriores é uma situação ideal, uma vez que caracteriza uma certa legitimidade, o que permite a negociação/manutenção de relações com diferentes estados e Entidades. O autor chama a atenção para tal fato, pois, foi com o argumento da "preservação da democracia", por parte do governo, que o conflito de 07 de junho, tomou proporções mais drásticas. Mas o governo ( nem nesse aspecto), levou em consideração os anseios da população apesar do Estado de Sítio, em que o pais se encontrava. E recrutou militares estrangeiros.

Antonieta Rosa Gomes ${ }^{69}$ chama ainda a atenção para o fato de que na GuinéBissau, a democracia surgiu como resultado da evolução do Estado e pelo condicionalismo internacional para ajuda financeira. De acordo com a mesma autora, foi neste contexto que se implantou o multipartidarismo, mencionado anteriormente. Ainda de acordo com a mesma autora, o problema da democracia se coloca na GuinéBissau também pelo fato de existir no país, um poder real (militar), que não se subordina ao poder civil, não se submete à lei e a justiça e contra o qual, não se instaura o devido processo legal, para julgar e punir os arbítrios cometidos. Desta forma, a autora afirma, pode-se concluir que o princípio da legalidade na Guiné-Bissau é uma garantia formal, mas não de facto. Na prática, vigora a regra dos homens ao invés da lei. Ainda de acordo com mesma autora, a justiça deve ser um consenso que busque o bem do povo e garanta a sua integridade. As leis devem fundar-se na justiça e impor-se a todos para garantir a paz social. Pois a justiça constitui um fundamento do Estado de Direito.

\footnotetext{
${ }^{69}$ GOMES, Antonieta Rosa, O poder militar e a desedificação do estado de direito e da democracia na Guiné-Bissau. In $7^{\circ}$ Congresso Ibérico de Estudos Africanos, Lisboa, 2010 - 50 anos das independências africanas: desafios para a modernidade, Lisboa: CEA, 2010, Disponível em: http://hdl.handle.net/10071/2347, Acesso em: 17/06/2011.
} 
Já para Nelson Constantino Lopes ${ }^{70}$, a instabilidade político-militar a que, ainda se assiste na Guiné-Bissau, não começou com a abertura multipartidária adoptada em 1991, mas sim é a consequência de conflitos acumulados ao longo dos anos da luta armada de libertação nacional dentro do movimento da libertação, o PAIGC, que nunca foi resolvido cabalmente, deixando sequelas consideráveis no seio dos Antigos Combatentes.

Para o autor acima citado são as constantes sublevações fatores determinantes (a par de outros) para o fracasso de construção da democracia na Guiné-Bissau, e não o contrário. Tal fato, na opinião do autor, deve-se a um elevado e forte envolvimento da elite militar na política nacional, como detentores, de facto, do poder, tudo isso, aliado à fragilidade das instituições. De acordo com o mesmo autor:

"É verdade que não se pode exigir muito e a curto prazo das instituições, num país em que a democracia começa a fazer parte dos valores tradicionais da sociedade, como acontece aliás na maioria dos países africanos aspirantes a democracia, mas é necessário que haja vontade no seio da sociedade guineense, concretamente junto à classe política, em particular, para a fortificação das suas instituições, de modo a construir uma democracia assente em princípios aceites por todos e dentro das especificidades do país".

Por outro lado, é imperativo o respeito pelas normas constitucionais da GuinéBissau de forma a permitir a construção de um verdadeiro Estado de Direito, onde os militares obedecerão o poder civil democraticamente eleito e abster-se-ão de interferir continuadamente na governação, missão essa da competência civil.

\footnotetext{
${ }^{70}$ LOPES, Nelson, Constantino, As forças armadas num Estado em "Interrogação": Os Entraves À Construção E Consolidação Do Estado na Guiné- Bissau. In $7^{\circ}$ Congresso Ibérico de Estudos Africanos, Lisboa, 2010 - 50 anos das independências africanas: desafios para a modernidade, Lisboa: CEA, 2010, Disponível em: http://hdl.handle.net/10071/2347, Acesso em: 17/06/2011.
} 
Assiste-se na Guiné-Bissau de forma repetida e sistemática, a levantamentos militares com o objetivo de repor alguma ordem social ou justiça, que no entanto acabam em fracassos, devido à falta dum projeto político e de legitimação, instrumentos fundamentais para uma governação consistente.

\subsection{Fatores históricos: antecedentes do conflito de 1998 - a descolonização e suas} consequências.

Quando em 24 de setembro de 1973, o Partido Africano para a Independência da Guiné e Cabo-ver, (PAIGC), declarou unilateralmente a colônia da Guiné Portuguesa, como um Estado soberano independente, a partir daí conhecida como Rep+ublica da Guiné-Bissau, as forças anti-imperialistas e anti-coliniais mundias exultaram. Esperavase que este pequeno país da África Ocidental, cujos habitantes haviam consentido tantos sacrificios para se libertarem da opressiva dominação colonial portuguesa, iria implantar uma genuina independencia politica e econômica ${ }^{71}$.

O programa do PAIGC, e as suas numerosas declarações políticas, reforçaram durante o periodo da luta armada de libertação (1963-1974), a independência econômica e a unidade entre a Guiné-Bissau e Cabo-verde, e um desenvolvimento social e policitico radical assente na nas necessidades da maioria da população - mais de $80 \%$ eram habitantes de zonas rurais.

A dominação efetiva pelos portugueses do território que hoje contitui a Guiné remonta aos primórdias do século passado. Não foi senão em 1915 que a parte continental foi "pacificada", depois de séculos de tentativas para criar pelo menos uma colónia imformal, seguidos de décadas de desesperados esforços para corresponder à

${ }^{71}$ MENDY, Peter Karibe, Herança colonial e o desafio da integração, INEP, Pág. 03. 
exigencia da Conferência de Berlim (1884 1885) de "ocupação efetiva". Mas mesmo com a conquista final do território continental, a soberania portuguesa não foi estabelecida no arquipélago dos bijagós senão em 1936. A tradição de resistência continuou durante o breve periodo de dominação colonial efetiva, na forma de resistencia passiva, culminando em onze anos de luta armada pala libertação nacional. Com a pacificação do território, imediatamente os portugueses se voltaram para a tarefa de consolidar a sua dominação em termos de controle efetivo sobre os subjugados quer em termos de um firme controle da economia.

Desde a chegada das caravelas portuguesas provavelmente em 1446, Portugal declarou a sua missão de levar a "civilização" e a salvação aos "primitivos" e gentios. A missão civilizadora/evangelizadora foi sempre apresentada como o eixo da filosofia colonial portuguesa. Desde o iníco, as ambições territoriais e a exploração econômica foram equacionados em termos do cumprimento de um dever evangelizador - dever este que consistia, segundo o último ideólogo, Marcelo Caetano Ministro das colônias e Primeiro-ministro da ditadura do Estado novo fascista em Prtugal, em "arrancá-los das trevas do paganismo e salvar suas almas”. A exagerada função histórica de Portugal teve expressão legal no importante Acto Colonial de 1930, que estabeleceu formalmente o regime do Estado Novo na África Portuguesa. O Acto proclamava que era "a essência orgânica da Nação portuguesa" realizar a função histórica de possuir e colonizar dominios ultramarinos e civilizar as populações indígenas. A política portuguesa de assimilação era considerada parte integrante da doutrina colonial portuguesa e estava ligada à missão civilizadora, assente na crença da superioridade natural da cultura portuguesa. Considerados inferiores, os nativos das colônias tinham que ser gradualmente retirados da sua condição de primitivos e selvagens e civilizados à imagem dos portugueses. O processo envolveu a destruição de sociedades tradicionais, 
o inculcar da cultura portuguesa e a integração de assimilados "destribalizados" e lusitanizados na sociedade portuguesa. Tal missão civilizadora foi realizada principalmente através do trabalho e da educação.

Na Guiné Portuguesa, tal como em Angola e Moçambique, mas não em Caboverde, o duplo sistema de ensino estabelecido consistia na duplicação dos sistemas escolares primario e secundário metropolitanos por um lado e por outro em um programa de básico de instrução menos elaborado. O primeiro, denominado Ensino Primário Elementar e complementar, da responsabilidade do Estado Colonial, era destinado aos civilizados dos centros urbanos e seguia rígidamente os currículos das escolas primárias e secundárias metropolitanas. O segundo, denominado Ensino Rudimentar Primário, e da responsabilidade das missões católicas, era destinado a ensinar aos indígenas a "falar, ler e contar em português" bem como a inculcar neles hábitos de trabalho e atitudes conducentes ao abandono da indolência e à preparação de futuros trabalhadores rurais e artesãos. Contudo, não obstante a dualidade, a educação quer dos civilizados, quer dos indígenas tinha por objetivo criar e expandir um reservatório de colaboradores voluntários e capazes, com um mínimo de educação e preparação, mas com interesse na manutenção da paz lusitana. Basicamente era prática e funcional, e como tornou explícito o Cardeal Manuel Gonçalves, mais tarde, em 1960, não tinha a intenção de criar uma "inteligência". As escolas eram geralmente do tipo "para ensinar a lêr e escrever".

Logo após a pacificação foram feitos grandes esforços para assegurar a econômia do território como uma reserva especial para a exploração portuguesa. O comércio externo foi nacionalizado, e acompanhado de uma política de fiscalização rigorosa. A economia era essencialmente camponesa, não houveram grandes avanços tecnologicos de tal modo que no final dos anos 1970, António de Spinola viu-se 
obrigado a implementar uma politica de "Guiné melhor". A fraca atuação do colonialismo tambem se refletia no baixo desenvolvimento industrial. É nesse contexto que surge o PAIGC. Fundado em 1956 como um movimento de lilbertação nacional, tendo como principal objetivo imediato a independência política da dominação colonial portuguesa, o PAIGC adotou uma ideologia radical influênciada pela perspectiva marxista. Influência esta que se deveu ao fato de o Líder Amilcar Cabral, pai e fundador da nacionalidade guineense, cujos textos constituem o cerne da ideologia do PAIGC, ter se pautado pela ideologia socialista. Os princípios fundamentais da ideologia do PAIGC o eram, apesar da palavra socialismo não aparecer no programa original. O movimento estava engajado não só na tomada de independência como também na eliminação da exploração do homem pelo homem. Durante a luta de libertação o PAIGC libertou cerca de dois terços do território. Com a tomada da independência, que ocorreu concomitantemente como 25 de abril em Portugal, os libertadores confromtaram-se com problemas reais que não haviam previsto no seu programa, uma vez que este falava especialmente da libertação. A economia colonial se encontrava debilitada, tambem devido aos anos de guerra e requeria investimento substancial. A escassez de quadros obrigou a que os funcionários herdados da época colonial tivessem que ser mantidos, mas tal fato trazia desconfianças. O projeto de Amilcar Cabral de criar uma política econômica baseada na produção alimentar e no desenvolvimento da agriultura, não foi implantado após o seu brutal assassinato. A somar a esses fatos está a desorganização no processo de organização dos poderes que culminou com a crise da deposição de Luis Cabral. Foi após a descolonização e com a morte de Amílcar Cabral, que os objetivos do PAIGC se começaram a perder e surgiu a idéia de merecimento de deter o poder por parte dos militares, proveniente da ideoologia de heroicidade herdada pela vitória na expulsão dos colonizadores e o seu regime. 


\subsection{O Conflito armado de 1998.}

\subsubsection{As Razões do conflito.}

Após a conquista da independência política de Portugal em 1974, a GuinéBissau optou por um modelo de desenvolvimento inspirado no modelo socialista, com base no mono partidarismo comandado pelo PAIGC $^{72}$, partido que conduziu a luta de libertação nacional contra o colonialismo português ${ }^{73}$. Após um período de razoável crescimento econômico seguiu-se uma aguda crise econômica que chegou a provocar a escassez de alimentos. O Estado havia-se revelado incapaz de resolver os problemas da população e as tarefas politicas tornaram-se cada vez mais complexas.

Em 12 de novembro de 1980, a Assembleia Nacional Popular, em sessão extraordinária, aprovou o texto da nova constituição que dava ainda mais liberdades e poderes aos membros do governo, o que se traduziu em desconfianças, e perseguições e seria a base para a instabilidade politica. Nesse ambiente de conflitos no seio do PAIGC, em 14 de novembro de 1980 (seis anos após a independência) foi perpetrado o golpe de Estado liderado pelo General João Bernardo Vieira. Com o golpe, a ala caboverdiana do PAIGC se separa da ala guineense do partido, o que faz malograr o plano de fusão política entre Guiné-Bissau e Cabo Verde. Ambos os países romperam relações, que somente seriam reatadas em $1982^{74}$.

\footnotetext{
${ }^{72}$ PAIGC é a sigla para Partido Africano para a Independência da Guiné e Cabo Verde. Foi o movimento que organizou a luta pela independência da Guiné-Bissau e de Cabo Verde, que eram colônias de Portugal. Atualmente, o PAIGC é um dos principais partidos políticos da Guiné-Bissau.

${ }^{73}$ CARDOSO, Carlos, A transição democrática na Guiné-Bissau : um parto difícil, In: Transitions liberales en Afrique lusophone, Paris, Ed. Karthala, 1995. - p. 259.

${ }^{74}$ RUDEBECK, Ars, Colapso e Reconstrução Política na Guiné-Bissau 1988-2000, Upsala, Nordiska Afrikainstitutet, 2001.
} 
Em 1985 ocorre um novo caso de conflito no PAIGC e resulta na detenção de 60 pessoas, acusadas de conspiração, seis dos detidos são fuzilados e os restantes condenados a penas de prisão que variaram entre 1 e 51 anos, tendo seis dos presos falecido na prisão ${ }^{75}$.

Com a crise instalada, o país se viu obrigado a realizar urgentes reformas econômicas e políticas que resultaram na adoção dos Programas de Ajustamento Estrutural e a abertura ao multipartidarismo. Em 1992 assistiu-se à criação de várias formações partidárias, o que culminou, em 1994, com a realização das primeiras eleições.

Em 7 de junho de 1998 eclodiu a guerra. Em maio de 1997, numa tentativa de aprofundar a cooperação a nível regional e fazer frente à aguda crise que o país vivia em termos econômicos, políticos e sociais, a Guiné-Bissau torna-se membro da União Econômica e Monetária da África Ocidental (UEMOA), tendo aderido à moeda do grupo, o franco CFA. O que se pensava ser uma medida que permitiria uma maior estabilidade monetária e a criação de um ambiente mais atrativo para o investimento externo, veio a revelar-se uma medida desastrosa tanto a nível econômico, como social, porque não foi acompanhada de medidas macroeconômicas sólidas capazes de sustentar o desenvolvimento, levando assim a um aumento da pressão externa, nomeadamente dos Estados francófonos vizinhos, principalmente do Senegal, e a uma consequente descapitalização do país. Tal crise, associada à crise no PAIGC, que embora não fosse o partido único, era, ainda, o partido de maior expressão no país, e nas Forças Armadas,

75 SANGREMAN,Carlos; SOUZA, JR., Fernando; ZEVERINO,Guilherme; BARROS, Miguel, A evolução política recente na Guiné-Bissau: As eleições presidenciais de 2005, Os conflitos, O desenvolvimento. A sociedade civil, Colecção Documentos de Trabalho, $\mathrm{n}^{\circ} 70$, Centro de Estudos sobre África e do Desenvolvimento do Instituto Superior de Economia e Gestão da Universidade Técnica de Lisboa, Lisboa, 2006, p. 14. 
culminou no conflito militar. Mas, este deve ser analisado numa perspectiva que abarque também a sua dimensão externa.

Um dos aspectos desta dimensão externa prende-se com a relação entre Portugal e França no que respeita à Guiné-Bissau. A relação entre as políticas de ajuda ao desenvolvimento e as raízes dos conflitos armados impõem que se analise de forma crítica o papel que a cooperação para o desenvolvimento pode ter. Tanto para os doadores oficiais, neste caso Portugal e França, como para os não governamentais, é fundamental refletir sobre as consequências das suas políticas, retirando as necessárias ilações da noção de que uma cooperação mal orientada pode produzir efeitos altamente indesejáveis a médio e longo prazo ${ }^{76}$. Para explicar tal relação faz-se necessário elucidar a questão da Casamansa, que se encontra subjacente à crise nas forças armadas.

\subsubsection{A Sua "regionalização".}

A região de Casamansa, integrada atualmente no Senegal, teve, desde sempre, grandes afinidades com o território da então Guiné Portuguesa, na medida em que até à realização da conferência de Berlim, Casamansa era uma região portuguesa. Após a referida Conferência, a zona de Casamansa passou a ser território francês, o que de certa forma separou povos que tinham ligações históricas e culturais, e que pode ser explicado pelo apoio que o Movimento das Forças Democráticas de Casamansa (MFDC) teve do lado Bissau Guineense da fronteira. Nesse contexto, os guerrilheiros do MFDC habituaram-se a contar com o auxílio dos guineenses em termos de fornecimento de armamento e apoio logístico. Tal apoio assentava no fato de existir uma ligação étnica entre o povo de Casamansa, maioritariamente da etnia Diola ou

\footnotetext{
${ }^{76}$ SANGREMAN, Carlos, (Et.al.) Op. Cit. P.16.
} 
Djola e o povo do norte da Guiné que são do mesmo grupo étnico, apesar da nomenclatura diferente, (na Guiné-Bissau, são chamados Felupes). Vale dizer que tal ajuda não era oficial ${ }^{77}$.

É neste contexto que, em finais de 1997, é decidido pelo Governo guineense a criação de uma Comissão Inter-Ministerial, integrando elementos dos ministérios da Defesa e Administração Interna, para investigar a questão do tráfico de armas da GuinéBissau para os guerrilheiros de Casamansa. Finalizado o trabalho, esta Comissão produziu um relatório considerado polémico. Dada a natureza e importância da questão também a Assembleia Nacional criou uma Comissão Parlamentar de Inquérito sobre o Tráfico Ilegal de Armas para os Independentistas de Casamansa, que produziu um relatório após cerca de dois meses de investigações onde recomendava que, em face da não existência de acusações que ligassem o Chefe de Estado-Maior General das Forças Armadas Brigadeiro Ansumane Mané ao tráfico de armas, fosse revisto o processo de suspensão do cargo que ocupava ${ }^{78}$.

O conflito guineense e o seu desfecho eram particularmente importantes para o Senegal que via numa eventual vitória da Junta Militar o aumento, desta vez aberto, do apoio da Guiné-Bissau à luta do MFDC. A intervenção senegalesa ficou conhecida com o nome "Operação Gabú", tendo o contingente senegalês sido comandado pelo Coronel Abdoulaye Fall $^{79}$.Ou seja, o conflito político militar que começou como uma crise interna, assumiu depois uma dimensão regional com a intervenção das tropas do Senegal e da Guiné-Conakry. As intervenções entre os aspectos puramente internos e os decorrentes da intervenção externa influíram nas caracteristicas e na duração da crise,

\footnotetext{
${ }^{77}$ SANGREMAN,Carlos (Et. Al.) Op. Cit. P. 18.

78 TEIXEIRA, Ricardino Jacinto D., Sociedade Civil, Direitos Humanos e a construção da democracia na Guiné-Bissau: limites e possibilidades, 2008, Disponível em: www.africanidade.com/.../SOCIEDADE-CIVIL-DIREITOS.

${ }^{79}$ SANGREMAN,Carlos (Et. Al.) Op. Cit. P. 19.
} 
pesando significativamente sobre a evolução do que à partida era um motim de reivindicações limitadas, para um levantamento de envergadura nacional, de dimensões populares e contornos complexos ${ }^{80}$. A intervenção das tropas estrangeiras influíu no resultado do conflito, na medida em que acabou influenciando o posicionamento dos atores internos da crise. Enquanto o Presidente da República justificava a presença estrangeira como necessária ao reestabelecimento da ordem democrática, os rebeldes oposicionistas denunciaram o recurso como uma invasão ilegal e conseguiram o apoio de grande maioria da população, tranformando o que antes era à priori uma sublevação/motim militar num levantamento politico-militar quase libertador, que se autodenominou Junta militar do povo. Vale dizer que para conseguir o apoio da população, também pesou a violência exercida sobre os civis, os abusos de autoridade e os atos de pilhagem atribuidos às tropas estrangeiras.

Os esforços destinados a restaurar a paz entre os beligerantes começaram a surgir dos mais variados quadrantes. Para além de iniciativas internas, de autoridades religiosas, tradicionais e parlamentares, surgiram também iniciativas externas, sendo de destacar ao nível bilateral as contribuições da Gâmbia, Angola e Portugal e ao nível multilateral a Comunidade dos Países de Língua Portuguesa (CPLP) e a Comunidade Económica dos Estados da África Ocidental (CEDEAO).

O fim da guerra teve por consequência a deposição do presidente do cargo e a formação de um "governo de transição" que prepararia novas eleições ${ }^{81}$.

A vitória do candidato Kumba Yala e do Partido para a Renovação Social (PRS) deu início a um novo ciclo neste país, que depressa ficou marcado pelo agudizar da crise econômica e social, pela perda de credibilidade da Guiné-Bissau ao nível internacional,

\footnotetext{
${ }^{80}$ KOUDAWO, Fafali, Op. Cit, Pág. 144.

${ }^{81}$ CARDOSO, Carlos, Compreendendo a crise de 7 de junho na Guiné-Bissau, In Soronda Revista de Estudos Guineenses, Edição Especial 7 de Junho, 2000, pág 87.
} 
pelo declínio das instituições, pela desresponsabilização das autoridades, pelo desrespeito pela Constituição e pela crise entre a Presidência, os órgãos da Justiça e a Assembleia Nacional.

As expectativas criadas com os progressos alcançados com o acordo de paz, a nomeação de um Governo de Unidade Nacional e a realização das eleições gerais em 1999/2000, se viram frustradas com as flagrantes violações dos direitos humanos, as perseguições e prisões arbitrárias de jornalistas, de órgãos de comunicação social, de políticos, de Juízes do Supremo Tribunal da Justiça, de cidadãos comuns e o desrespeito pela Constituição da República e o princípio da separação de poderes ${ }^{82}$.

Neste contexto, o mandato do Presidente da República Kumba Yala (20002003), interrompido por um golpe de Estado, que novamente pôs em evidência todas as debilidades existentes no país e ficou marcado por uma enorme instabilidade política e $\operatorname{social}^{83}$.

Na época foi criada a Carta de Transição Política, instrumento que substituiu transitóriamente a Constituição da República, introduzindo ou redistribuindo os poderes do Estado por alguns órgãos provisórios entretanto criados (Comité Militar e Conselho Nacional de Transição). Assim, o Poder passou a ser partilhado entre os políticos, militares e algumas organizações da sociedade civil. Um Presidente e um Governo de Transição foram nomeados, tendo a frente dois civis. Mais tarde o Poder Judicial, nomeadamente os Juízes do Supremo Tribunal de Justiça foram eleitos pelos seus pares em conformidade com critérios eleitorais próprios que se baseiam na independência e

\footnotetext{
82 HANDEM, Jamel, FIM DA TRANSIÇÃO POLÍTICA - OS NOVOS DESAFIOS PARA A CONSTRUÇÃO DA PAZ E DA ESTABILIDADE, Disponível em: Www.pimemilano.com/index.php?idn=510, Acessado em 17/06/2011.

83 DJALÓ, Iaguba, O conflito politico militar na Guiné-Bissau e os desafios da reconstrução e recuperação da memória e da identidade nacional, In Soronda Revista de Estudos Guineense, 2004, nº pág. 97-107.
} 
democracia interna desse Órgão do Poder do Estado ${ }^{84}$. São novamente convocadas as eleições legislativas, que em 30 de Março de 2004, que deram a vitória ao PAIGC.

No entanto, mais uma vez, os elementos sempre presentes que estão na origem dos conflitos na Guiné-Bissau, em que podemos destacar a falta de diálogo para a resolução dos problemas do país por vias não violentas, são de novo postos em evidência com o assassinato do General Veríssimo Seabra, em Outubro de 2004. Tratase da agudização da crise que leva à queda do governo.

São convocadas eleições que são constantemente proteladas, até que em 2006 se realizam as eleições que dão a vitória ao presidente deposto aquando da guerra de 7 de junho, o General João Bernardo Vieira.

Em 2009, num ataque, cujas circunstancias e perpetradores até hoje continuam uma incógnita, o então presidente João Bernardo Vieira e o Comandante das Forças Armadas são assassinados. Posteriormente são realizadas eleições que dão a vitória ao presidente Malam Bacai Sanhá.

Vale dizer, a título de atualização, que após o falecimento do presidente (desta vez por doênça), se convocaram eleições que deram início a uma nova crise que culminou com o golpe de Estado que depôs o presidente interino Raimundo Pereira e o primeiro-ministro Carlos Gomes Júnior, e criou uma situação de transição, cujo término se encontra previsto com a realização de eleições marcadas para abril de 2013.

\footnotetext{
${ }^{84}$ HANDEM, Jamel, Op. Cit. P.1.
} 


\subsubsection{As Negociações de paz: análise dos acordos assinados.}

Reunidas em Abuja, na Nigéria, sob a égide da CEDEAO, as partes em conflito reafirmaram o acordo de cessar-fogo assinado em 26 de Agosto de 1998 na Cidade da Praia, e assinaram o Acordo de paz, denominado acordo de abuja que contemplava cinco pontos a saber:

1. Reafirmação do acordo de cessar-fogo assinado em 26 de Agosto de 1998 na cidade de Praia (República de Cabo Verde);

2. Retirada total dos militares estrangeiros, simultaneamente com o envio de uma força de interposição da ECOMOG (braço armado da Comunidade Econômica para Desenvolvimento da África Ocidental - CEDEAO) que as substituirá;

3. A força de interposição garantirá a segurança na fronteira com o Senegal, manterá as partes separadas e permitirá às organizações humanitárias livres acesso às populações civis. Ao mesmo tempo, o Aeroporto de Bissalanca, que esta sob o domínio da Junta Militar, será abertos;

4. Formação de um Governo de Unidade Nacional (GUN) que, segundo o acordo, deverá incluir, além dos representantes do presidente Nino e da Junta Militar, os representantes das outras formações políticas;

5. Preparação e convocação das eleições legislativas e presidenciais para 1999, sob a supervisão da comunidade internacional.

O Acordo celebrado em Abuja, sob a égide da CEDEAO, a 1 de Novembro de 1998, entre o Governo da Guiné-Bissau e a auto-proclamada Junta Militar, embora frágil, e extremamente simpples, denotando que objetivava unicamente a favorecer o 
fim da guerra e das suas causas imediatas, continha de cláusulas de âmbito militar e de âmbito político. No âmbito político correspondia a um estado de excepção, na medida em queo Acordo de Abuja suspendia parcialmente a Constituição, quanto à organização do poder político, mas permitia que, uma vez realizadas eleições, ela pudesse readquirir plena força jurídica ${ }^{85}$. No entando só em 20 de Fevereiro de 1999 foi possível empossar o previsto Governo de Unidade Nacional (GUN). A 7 de Maio reacendeu-se a o conflito e depois de violentos combates, Nino Vieira aceitou a rendição incondicional (Declaração de rendição, de 8 de Maio de 1999). No mês seguinte, através da Declaração de renúncia, de 2 de Junho, declinou o mandato presidencial, permitindo a sua substituição "nos termos da Constituição da República". Perante a vacatura, em 14 de Maio assumiu funções na qualidade de PR interino o então Presidente da ANP, Malam Bacai Sanhá, que confirmou a realização de eleições legislativas e presidenciais para 28 de Novembro desse ano. Como o Acordo de Abuja podia considerar-se caducado, subscreveu-se um Pacto de Transição Política, a 21 de Maio. Ao longo de 5 títulos e 17 artigos, nele se enunciava o quadro legal para a condução do País à normalidade constitucional.

\subsection{O Papel da Organização da Unidade Africana e das organizações regionais.}

Á semelhança da posição das Nações Unidas, A OUA condenou o conflito e deu início ás conversações para a negociação da paz. Trabalhando em colaboração com a CEDEAO, a organização fez apelos ao apoio da comunidade internacional e das instâncias regionais para a resolução do conflito, e o restabelecimento da paz.

\footnotetext{
${ }^{85}$ SILVA, Antonio E. Duarte, As Constituições da Guiné-Bissau. Que constitucionalismo?, Seminário "Debater a Constituição da Guiné-Bissau” UNIOGBIS/FDB, 2010.
} 
O conflito constituiu flagrante violação aos principios da Carta da OUA que preconizam a paz e a via democrática para a resolução de conflitos. No entanto foram as organizações subregionais na figura da CEDEAO e da CPLP que se engajaram firmemente na resolução do conflito e na busca pela paz. Do mesmo modo, após o conflito foi a CEDEAO, através da ECOMOG, que empregou esforços empenhadamente, no sentido de reunir as condições necessárias à criação do mínimo de estabilidade que permitisse a gradual volta à normalidade.

\subsection{A Organização das Nações Unidas (ONU) e os conflitos na Guiné-Bissau - importância da ONU.}

A ONU foi Fundada em 24 de outubro de 1945, na cidade de São Francisco, após o flagelo da Segunda Grande Guerra, em substituição à Liga das Nações. Advinda da necessidade de criar uma organização que se dedicasse à preservação da paz, a ONU foi criada de forma a evitar que o mundo voltasse a conhecer os horrores das guerras anteriores. Ainda no clima do pós-guerra, a ONU procurou desenvolver mecanismos multilaterais para evitar novos conflitos armados de carácter mundial.

A Carta das Nações Unidas define em ser artigo $1^{\circ 86}$, como seus objetivos principais em termos gerais:

\footnotetext{
${ }^{86}$ Carta da ONU -Artigo 1a: Os propósitos das Nações unidas são:

1. Manter a paz e a segurança internacionais e, para esse fim: tomar, coletivamente, medidas efetivas para evitar ameaças à paz e reprimir os atos de agressão ou outra qualquer ruptura da paz e chegar, por meios pacíficos e de conformidade com os princípios da justiça e do direito internacional, a um ajuste ou solução das controvérsias ou situações que possam levar a uma perturbação da paz;

2. Desenvolver relações amistosas entre as nações, baseadas no respeito ao princípio de igualdade de direitos e de autodeterminação dos povos, e tomar outras medidas apropriadas ao fortalecimento da paz universal;
} 
(i) Manter a paz e segurança mundiais, por meio de medidas efetivas, preferencialmente pacíficas, em conformidade com a justiça e o direito internacional,

(ii) Promover a cooperação internacional na solução dos problemas econômicos, sociais e humanitários e,

Para que estes propósitos se concretizem, a ONU estabelece uma serie de medidas adotadas pelo Conselho de Segurança, que consideram a possibilidade ou não possibilidade do emprego da força armada. Com o advento da Carta das Nações Unidas, consagrou-se um princípio geral de monopólio do uso da força e de ameaça de uso da força e não somente da guerra, tal como se limita a declarar o Pacto Briand-Kellog ${ }^{87}$.

O princípio fundamental da Carta das Nações unidas de manutenção da paz e segurança internacionais resulta da conjunção de todos os princípios do Artigo 2, e de preâmbulo da mesma, pois representa o máximo propósito da ONU, facilmente identificado nas atribuições do Conselho de Segurança, como órgão que detém o monopólio do uso da força. Não se trata, portanto, de um princípio de proibição do uso da força, mas da regulação deste pelo orgão.

Carrilo Salcedo ${ }^{88}$ divide a história da ONU em três etapas. A primeira corresponde à chamada guerra fria, período que durou de 1945 a 1991, marcado pela rivalidade entre os Estados Unidos e a União Soviética que repercutiu de maneira negativa sobre o Conselho de Segurança e fez da Assembléia Geral um órgão sem poder decisório.

3. Conseguir uma cooperação internacional para resolver os problemas internacionais de caráter econômico, social, cultural ou humanitário, e para promover e estimular o respeito aos direitos humanos e às liberdades fundamentais para todos, sem distinção de raça, sexo, língua ou religião; e

4. Ser um centro destinado a harmonizar a ação das nações para a consecução desses objetivos comuns.

${ }^{87}$ Pacto Briand-Kellog é o nome pelo qual ficou conhecido o General Treaty for Renunciation of War as an Instrument of National Policy (Tratado Geral para Renúncia da Guerra como Instrumento de Política Nacional) assinado em Paris em 26 de outubro de 1928. O pacto compreende três artigos que representaram um progresso do jus ad bellum para o jus contra bellum.

${ }^{88}$ SALCEDO, Juan Antonio Carrillo apud RIDRUEJO, José A., Curso de Derecho Internacional Publico y Organizaciones Internacionales, Pág.702. 
A segunda etapa corresponde aos movimentos de descolonização que tiveram importante impulso a partir de 1960, quando a Assembléia Geral aprovou a Resolução A/RES/XV/1415 de 14 de dezembro de 1960, e em 1970, quando a Resolução A/RES/XXV/2625 de 24 de outubro de 1970 incorpora o princípio da igualdade de direitos e autodeterminação dos povos aos princípios de direito internacional sobre relações de amizade e cooperação entre os Estados em conformidade com a Carta das Nações Unidas. Em verdade, as resoluções da AG somente deram impulso a princípios que haviam sido concebidos e já faziam parte da própria Carta (Artigos 2,55 e 73).

A terceira etapa da ONU foi determinada por uma nova concepção dos fins e funções das ONU, já não unicamente de manutenção da paz, mas também de promovedor do desenvolvimento e luta contra a pobreza, o que se pôde perceber durante a década de 70 quando aderiram à ONU novos Estados africanos recém independentes e os desafios do mundo mudavam de enfase.

No sistema das Nações Unidas, a responsabilidade pela manutenção da paz e da segurança internacionais cabe ao Conselho de Segurança, como consta do artigo 24. Também cabe ao Conselho de Segurança a responsabilidade pela declaração de existência, ou não, de qualquer ameaça à paz, ruptura da paz ou ato de agressão, responsabilidades que terá que exercer respeitando os Propósitos e Princípios das Nações Unidas.

É importante destacar que, a primeira dessas funções deriva do Artigo 2, Parágrafo 3 e 4 da Carta e se complementa com o Capítulo VI, cujas disposições cuidam dos instrumentos e meios para a solução pacífica de controvérsias que possam a vir a constituir uma ameaça à paz e à segurança internacionais, as quais são solucionadas através de procedimentos e métodos recomendados pelo Conselho de Segurança ou, em 
se tratando de controvérsia de caráter jurídico, sob recomendação de serem solucionadas pela Corte Internacional de Justiça.

Já o exercício da segunda função, nos moldes do Capítulo VII, decorre da convicção de existência da ameaça à paz e à segurança internacionais, cujo restabelecimento por ser conduzido através de três categorias de medidas: medidas coercitivas que não impliquem o uso da força armada (Artigo 41), medidas coercitivas que impliquem no uso da força armada (Artigo 42).

É nesse conjunto de medidas de busca de paz que se inserem as operações de paz e a constituição de tribunais penais ad hoc, que embora não estejam expressamente previstas, na Carta são reconhecidas como medidas próprias do Capítulo VII,.

Como dito anteriormente, as operações de paz e a criação de tribunais criminais ad hoc não encontram fundamento expresso na Carta. Ou seja, não se encontram expressamente determinadas nem no Artigo 41, nem no artigo 42 da Carta, No entanto, as menções expressas quanto a quebra da paz nas resoluções do Conselho de Segurança, com as referências ao Artigo 39, ou genericamente ao Capítulo VII, fortalecem o entendimento de que as operações de paz e os tribunais penais ad hoc se inserem entre as medidas num sentido mais amplo, de que se pode valer o Conselho de Segurança para realizar sua função de manutenção da paz e da segurança internacionais.

É nesse ponto que se insere o envolvimento da ONU na procura de paz na GuineBissau. Enquanto principal organização mundial responsável pela manutenção da paz, e sendo a Guiné-Bissau membro da organização, foram desenvolvidas, em cooperação ativa com as organizações regionais, as atividades necessárias para que se alcançasse a paz no país, ou pelo menos, para que a guerra terminasse. Sobre a cooperação com as organizações regionais, vale dizer que a ONU incentiva e trabalha em parceria com as 
mesmas, na medida em que reconhece explicitamente a complementaridade que deve existir entre os sistemas regional e multilateral. A Carta da ONU em seu artigo $52^{89}$ previu a importância da cooperação regional e sub-regional na manutenção da paz e da segurança internacionais. O próprio Conselho de Segurança na Resolução S/RES/2033 $(2012)^{90}$ reafirma a importância da cooperação com organizações regionais e subregionais. Tal cooperação não implica na renúncia da responsabilidade primária de manutenção da paz e segurança internacionais do Conselho de Segurança., antes se trata de um meio eficaz de junção de sinergias para alcançar um bem comum. As potenciais vantagens das organizações regionais e sub-regionais, que geralmente tem condições geográficas, de conhecimento do território e da realidade local bastante efetivo são muito importantes tanto no campo da prevenção quanto no da resolução de conflitos.

Nas palavras de Maria Luiza Ribeiro Viotti ${ }^{91}$ A cooperação entre a ONU e as organizações regionais e sub-regionais tem-se provado benéfica na área da manutenção da paz. As organizações regionais e sub-regionais, por serem únicas, cada uma produto de uma cultura política específica, podem oferecer assistência especializada de valor inestimável para o Conselho de Segurança no exercício de sua responsabilidade

\footnotetext{
${ }^{89}$ O Capítulo VIII sobre acordos regionais da Carta da ONU, dispõe em seu Artigo 52:

1. Nada na presente Carta impede a existência de acordos ou de entidades regionais, destinadas a tratar dos assuntos relativos à manutenção da paz e da segurança internacionais que forem suscetíveis de uma ação regional, desde que tais acordos ou entidades regionais e suas atividades sejam compatíveis com os Propósitos e Princípios das Nações Unidas.

2. Os Membros das Nações Unidas, que forem parte em tais acordos ou que constituírem tais entidades, empregarão todo os esforços para chegar a uma solução pacífica das controvérsias locais por meio desses acordos e entidades regionais, antes de as submeter ao Conselho de Segurança.

3. Conselho de Segurança estimulará o desenvolvimento da solução pacífica de controvérsias locais mediante os referidos acordos ou entidades regionais, por iniciativa dos Estados interessados ou a instância do próprio conselho de Segurança.

${ }^{90}$ Resolução S/RES/2033 (2012).

${ }^{91}$ Representante Permanente do Brasil junto às Nações Unidas em discurso apresentado em 13 de Janeiro de 2010, ao Conselho de Segurança, entitulado Cooperação entre as Nações Unidas e organizações regionais e sub-regionais na manutenção da paz e da segurança internacionais. Disponível em: http://www.brasil-cs-onu.com/cooperacao-entre-as-nacoes-unidas-e-organizacoes-regionais-e-sub-re gionais-na-manutencao-da-paz-e-da-seguranca-internacionais/
} 
primária. Sendo, portanto uma base sólida para uma cooperação frutífera e mutuamente benéfica. Como anteriormente mencionado, o papel da ONU na resolução do conflito guineense foi realizado em um primeiro momento em coordenação com as organizações regionais, nomeadamento a CEDEAO, a CPLP e a UA, em que atuava como observador, sendo constante informado pelas organizações regionais sobre os avanços ou retrocessos obtidos na negociação do término do conflito. Em um segundo momento, após a assinatura dos acordos de paz, teve papel mais ativo, nomeadamente no apoio concreto dado à criação de fundos de assistência que suportassem as ações realizadas pela ECOMOG e posteriormente a sua consolidação com a criação de uma Operação de Consolidação da Paz.

\subsubsection{Análise das resoluções do Conselho de Segurança da ONU sobre a Guiné-Bissau} de 1999 a 2012.

A análise das resoluções do Conselho de Segurança permite ter uma noção mais clara do papel da ONU no processo de paz da Guiné-Bissau, apartir do fim do conflito politico-militar, permite também analisar a evolução gradativa do processo de busca de paz guineense, sob a ótica do Sistema das Nações Unidas e introduzir o papel das operações de paz nesse processo.

É comum, nas primeiras resoluções, que datam do periodo imediato ao fim do conflito, o Conselho de segurança reafirmar o compromisso de preservar a unidade, soberania, independência política e a integridade territorial da Guiné-Bissau, na medida em que se debatia e tratava da retirada das tropas estrangeiras do Senegal e da Guiné- 
Conkakri, que se encontravam no país a pedido do posteriormente deposto presidente João Vieira.

A primeira resolução após o conflito, S/RES/1216 de 1998, propõe o estabelecimento de um governo de unidade nacional, a realização de eleições presidenciais para até março de 1999, a retirada de tropas estrangeiras e o estabelecimento da Força de interposição do grupo de observadores militares (ECOMOG) da CEDEAO. No ponto 3 Fala do papel da ECOMOG na implementação do Acordo de Abuja, e na garantia de segurança na fronteira entre a Guiné-Bissau e o Senegal, afastando as partes em conflito e garantindo o livre acesso das organizações humanitárias e agências à população civil afetada. Solicita ao Secretário-Geral que faça recomenções ao Conselho sobre um possivel papel das Nações Unidas no processo de paz e reconciliação na Guiné-Bissau, incluindo o estabelecimento de arranjos entre a ONU e a ECOMOG.

Já a Resolução S/RES/1233 de 6 April 1999 trata da tomada de posse do Governo de Unidade Nacional, que encontrava sérios obstáculos ao seu funcionamento efetivo, devido à falta de funcionários públicos e outros quadros profissionais que havia fugido da guerra, procurando refúgio em outros países. A referida Resolução congratula o estabelecimento do mandato de peacekeeping da ECOMOG, apela a todos os Estados e organizações regionais a providenciar apoio técnico e logístico e a realizar contribuições financeiras para a ECOMOG, inclusive através do Fundo criado pela ONU, para apoiar a manutenção da paz na Guiné-Bissau. Apela, ainda aos partidos a marcação das eleições.

A Resolução S/RES/1580 de dezembro de 2004 reconhece a fragilidade do processo de transição e os riscos de poder falhar, dados os novos acontecimentos de 
violência e assasinato de duas altas patentes do Exército, nomeadamente, o Chefe do estado maior, o General Veríssimo Seabra o Coronel Domingos Barros e, reconhece que os constantes atos de instabilidade dificultam o dsenvolvimento social e economico. Em razão desses acontecimentos requer a extensão do mandato da UNOGBIS, para um ano apartir da data de adoção da resolução, e revê o mandato da mesma nos seguintes aspectos:

(a) Apoiar todos os esforços que reforçem diálogo político, promovera reconciliação nacional e o respeito pelo Estado de direito e direitos humanos;

(b) Apoiar os esforços de todos os intervenientes nacionais de forma a assegurar o pleno restabelecimento da normalidade constitucional em conformidade com as disposições da Carta de Transição Política de 28 de Setembro de 2003, nomeadamente através da realização de eleições presidenciais livres e transparentes;

(c) Auxiliar nas eleições, em estreita cooperação com os países da equipe da ONU e outros parceiros internacionais;

(d) Auxiliar no fortalecimento dos mecanismos de prevenção de conflitos nacionais durante o restante do período de transição e depois deste.

(e) Incentivar e apoiar os esforços nacionais para a reforma do sector da segurança, incluindo o desenvolvimento de relações civis-militares estáveis, e atrair o apoio internacional para esses esforços;

(f) Encorajar o Governo a implementar totalmente o Programa de Ação para Prevenir, Combater e Erradicar o Comércio Ilícito de Pequeno Armas e Armas Leves das Nações Unidas, em todos seus aspectos; 
(g) Trabalhar em estreita colaboração com o Coordenador Residente e a equipe de países da ONU de forma a mobilizar a assistência financeira internacional que vai permitir que o Governo possa atender suas necessidades financeiras e logisticas imediatas e implementar sua estratégia de reconstrução nacional e desenvolvimento económico e social;

(h) No âmbito de uma estratégia de construção de paz abrangente, apoiar activamente os esforços do sistema das Nações Unidas e outros parceiros da Guiné-Bissau no sentido de reforçar as instituições do Estado e as estruturas que permitam o respeito ao Estado de direito, aos direitos humanos, ao livre e independente funcionamento dos poderes executivo, legislativo e judiciário.

A Resolução S/RES/1876 de 26 de junho de 2009 chama a atenção para o ressurgimento da violência política, para a importancia das eleições presidenciais marcadas para junho de 2009, como passo necessário para o retorno da ordem constitucional e para a consolidação da democracia. Menciona a necessidade de se manter o compromisso, por parte do governo guineense, com a reforma do setor de segurança e fala da luta conta o tráfico de drogas. No que concerne à reforma no setor de segurança, reitera o apoio da ONU e da comunidade internacional para a manutenção da segurança e desenvolvimento a Guiné-Bissau a longo prazo, particularmente nos domínios da reforma do sector da justiça, e na construção da capacidade do Governo de lutar contra o tráfico ilícito de drogas. De notar que esta resolução frisa o aumento da fragilidade do Estado em razão do crescente tráfico de drogas, ameaçando a estabilidade da região. Extende o mandato da UNOGBIS até 31 de dezembro de 2009

A Resolução (S/RES/1949 (2010), de 23 de novembro de 2010, chama a atenção para a continuação da instabilidade, do aumento do tráfico de drogas, reafirma a 
importancia das reformas em curso, e eeitera a importancia da cooperação regional e subregional.

A Resolução S/RES/2030 de 21 de dezembro de 2011, reconhece os esforços do governo e da Assembléia em manter a estabilidade e a ordem constitucional, em promover o crescimento econômico, e as reformas institucionais. Verifica que tem havido um aumento do tráfico de drogas, apesar de esforços comprovados na luta contra o mesmo, reitera a importancia da cooperação regional e subregional. Reconhece o bom trabalho de coordenação da UNIOGBIS e extende o mandato desta até 28 de fevereiro de 2013.

A Resolução S/RES/2048 de 18 de maio de 20120, estebelece que a ONU em conjunto com a comunidade internacional, condena o golpe militar de 12 de abril, e as nefastas consequencias do mesmo sobre as reformas em curso, os avanços alcançados e o tráfico de drogas. Decide que todos os Estados-membros devem tomar as medidas necessárias para evitar a entrada ou o trânsito em seu território, dos individuos listados no anexo da resolução, ou designados pelo Comitê estabelecido em conformidade com o parágrafo 9 da resolução e afirma que essa regra não obriga o Estado a recusar a entrada dos seus próprios nacionais em seu território.

Da proposição da criação de um governo de unidade nacional, à condenação de mais um golpe de Estado, a análise das resoluções permite acompanhar o papel desenvolvido pela Organização, e o desenrolar dos acontecimentos no país. Dessa forma, pode-se perceber que são vários os osforços envidados em criar um clima de estabilidade e que estes vão acompanhando a realidade dos acontecimentos, o avanços e os retrocessos. Vale dizer que geralmente, os pontos analisados nas resoluções se referem aos trabalhos realizados pelas diferentes agências da Organização no país, e refletem os resultados por 
estas atingidos, que acompanham o andamento da situação politica, social e econômica no país. O grande número de recomendações denota a preocupação da Organização em ver o país trilhar o caminho da paz e a necessidade de se envidarem mais esforços a nivel internacional, mas principalmente a nivel interno, de forma a fazer frente às dificuldades que o país vem emfrentando, ainda assim, verifica-se uma real tentativa de adaptação à forma como vão se dando os acontecimentos.

Vale chamar atenção para importância do trabalho com conjunto com as organizações regionais e subregionais, que a exemplo, do que foi afirmado anteriormente estão bem posicionados para entender as causas dos conflitose da realidade do país, devido ao seu conhecimento da região. Vale dizer que tal conhecimento pode ser benéfico nos seus esforços para a prevenção e resolução de conflitos. 


\section{O PAPEL DAS OPERAÇÕES DE PAZ NA JUSTIÇA DE TRANSIÇÃO}

Durante a Guerra fria, o mundo se encontrava dividido em dois blocos comandados respetivamente pelos Estados Unidos e pela então União Soviética. Tal situação se refletia também no funcionamento do Conselho de Segurança que tinha que conviver com a dificuldade de tomar medidas eficazes para fazer valer os seus objetivos de manter a paz e segurança internacionais, dado que a Carta constitutiva da organização previa para os membros permanentes do Conselho de segurança o poder de veto. $\mathrm{O}$ poder de veto era usado de forma indiscriminada, dificultando o funcionamento do Conselho de Segurança, razão pela qual a Assembléia Geral por várias vezes teve que criar mecanismos para fazer como que a instituição funcionasse, como se verá mais para a frente, surgindo apartir dessas atividades um mecanismo novo que facilitava a realização dos objetivos de manter a paz e segurança internacionais preconizados pela Carta, a que se deu o nome de operações de manutenção da paz.

O termo manutenção de paz foi criado nos anos $1950^{92}$, mas a realização de missões visando a administração de conflitos e violência internacionais tem uma história mais antiga. Nas décadas de 1920 e 1930, com a Liga das nações, já realizavam missões, ainda que sem denominação específica, direcionadas à manutenção da paz e prevenção de conflitos. Nessas missões eram enviados observadores e forças militares para zelar pela ordem, administrar territórios em conflito e monitorar cessar-fogos.

Vale dizer que após as missões realizadas no âmbito da Liga das Nações têm-se as missões de supervisão de trégua agora, no âmbito das Nações Unidas que tinham como objetivo supervisionar o cumprimento de acordos de trégua e de cessar-fogo nas regiões

${ }^{92}$ BELLAMY, Alex J., WILLIAMS, Paul D., GRIFFIN, Stuart, Understanding peacekeeping, 2010, Polity Press. Pág. 200. 
onde eram empregadas. O primeiro caso se verificou na Grécia, em 1947, com a criação de um Comitê Especial das Nações Unidas para o Balcãs (United Nations Special Comitte on the Balkans), cujo mandato perdurou até $1954^{93}$.

No entanto, a que é reconhecida como a primeira missão de paz é a missão criada pelo Conselho de segurança da ONU no dia 29 de maio de 1948, por meio da Resolução 50(1948), na qual o Conselho de Segurança reconheceu as hostilidades entre judeus e árabes na Palestina, numa situação enquadrada no artigo 39 da Carta das Nações Unidas, ordenando às autoridades árabes e judaicas envolvidas nos conflitos que, de acordo com o artigo 40 da Carta, cessassem a utilização de forças militares e ordenassem o cessar-fogo às forças militares e paramilitares sob sua autoridade. Para verificação do cumprimento dessas determinações, o Conselho de Segurança ordenou que o desembarque no Oriente Médio dos primeiros observadores militares da $\mathrm{ONU}^{94}$.

Considerada a primeira operação de paz sob responsabilidade da ONU, foi chamada de UNTSO ( United Nations Truce Supervision Organization) e tinha por finalidade monitorar o cessar-fogo e supervisionar os acordos de paz.

Como anteriormente mencionado, em razão dos conflitos que surgiam no cenário internacional pós-Segunda Guerra Mundial, a ONU passou a autorizar uma série de missões que tinham por objetivo prevenir conflitos entre Estados ou tornar estável aqueles já em andamento, através da utilização de forças multinacionais compostas por civis e militares. O Conselho de Segurança, em sua qualidade de principal órgão do sistema das Nações Unidas responsável pela manutenção da paz e segurança internacional, e único dotado de poderes coercitivos, é que possui autoridade para aprovar o mandato das operações de paz. Apesar da Carta da ONU não fazer referência

\footnotetext{
${ }^{93}$ MORE, Rodrigo Fernandes, Fundamentos das operações de paz das Nações Unidas e a questão de Timor Leste, São Paulo, 2002.Pág. 63.

${ }^{94}$ MORE, Rodrigo, Op. Cit. Pág. 64.
} 
explícita a este tipo de operação, o que a torna um mecanismo ad hoc, o aparato que fundamenta juridicamente as missões de paz está previsto em seus Capítulos VI e VII ${ }^{95}$.

\section{${ }^{95}$ CAPÍTULO VI - SOLUÇÃO PACÍFICA DE CONTROVÉRSIAS}

Art $^{\circ} .33$ - As partes numa controvérsia, que possa vir a constituir uma ameaça à paz e à segurança internacionais, procurarão, antes de tudo, chegar a uma solução por negociação, inquérito, mediação, conciliação, arbitragem, via judicial, recurso a organizações ou acordos regionais, ou qualquer outro meio pacífico à sua escolha. O Conselho de Segurança convidará, se o julgar necessário, as referidas partes a resolver por tais meios as suas controvérsias.

$\mathrm{Art}^{\circ} .34$ - O Conselho de Segurança poderá investigar sobre qualquer controvérsia ou situação susceptível de provocar atritos entre as Nações ou de dar origem a uma controvérsia, a fim de determinar se a continuação de tal controvérsia ou situação pode constituir ameaça à manutenção da paz e da segurança internacionais.

$\mathrm{Art}^{\circ} .35$ - Qualquer membro das Nações Unidas poderá chamar a atenção do Conselho de Segurança ou da Assembleia Geral para qualquer controvérsia ou qualquer situação da natureza das que se acham previstas no $\mathrm{Art}^{\circ} .34$.

Um Estado que não seja membro das Nações Unidas poderá chamar a atenção do Conselho de Segurança ou da Assembleia Geral para qualquer controvérsia em que seja parte, uma vez que aceite previamente, em relação a essa controvérsia, as obrigações de solução pacífica previstas na presente Carta.

Os actos da Assembleia Geral a respeito dos assuntos submetidos à sua atenção, de acordo com este artigo, estarão sujeitos às disposições dos $\mathrm{Art}^{\circ} . \mathrm{s} 11$ e 12.

$\mathrm{Art}^{\circ} .36$ - O Conselho de Segurança poderá, em qualquer fase de uma controvérsia da natureza daquelas a que se refere o $\operatorname{Art}^{\circ}$. 33, ou de uma situação de natureza semelhante, recomendar os procedimentos ou métodos de solução apropriados.

O Conselho de Segurança deverá tomar em consideração quaisquer procedimentos para a solução de uma controvérsia que já tenham sido adoptados pelas partes.

Ao fazer recomendações, de acordo com este artigo, o Conselho de Segurança deverá também tomar em consideração que as controvérsias de carácter jurídico devem, em regra, ser submetidas pelas partes ao Tribunal (*) Internacional de Justiça, de acordo com as disposições do estatuto do Tribunal (*).

$\mathrm{Art}^{\circ} .37$ - Se as partes numa controvérsia da natureza daquelas a que se refere o $\mathrm{Art}^{\mathrm{o}}$. 33 não conseguirem resolvê-la pelos meios indicados no mesmo artigo, deverão submetê-la ao Conselho de Segurança.

Se o Conselho de Segurança julgar que a continuação dessa controvérsia pode, de facto, constituir uma ameaça à manutenção da paz e da segurança internacionais, decidirá se deve agir de acordo com o Art ${ }^{\circ}$. 36 ou recomendar os termos de solução que julgue adequados.

$\mathrm{Art}^{\circ} .38$ - Sem prejuízo das disposições dos $\mathrm{Art}^{\circ}$.s 33 a 37, o Conselho de Segurança poderá, se todas as partes numa controvérsia assim o solicitarem, fazer recomendações às partes, tendo em vista uma solução pacífica da controvérsia.

CAPÍTULO VII - AÇÃO RELATIVA A AMEAÇAS À PAZ, RUPTURA DA PAZ E ATOS DE AGRESSÃO

$\mathrm{Art}^{\circ} .39$ - O Conselho de Segurança determinará a existência de qualquer ameaça à paz, ruptura da paz ou acto de agressão e fará recomendações ou decidirá que medidas deverão ser tomadas de acordo com os $\mathrm{Art}^{\circ}$.s 41 e 42, a fim de manter ou restabelecer a paz e a segurança internacionais.

Art $^{\circ} .40$ - A fim de evitar que a situação se agrave, o Conselho de Segurança poderá, antes de fazer as recomendações ou decidir a respeito das medidas previstas no $\mathrm{Art}^{\circ}$. 39, instar as partes interessadas a aceitar as medidas provisórias que lhe pareçam necessárias ou aconselháveis. Tais medidas provisórias não prejudicarão os direitos ou pretensões nem a situação das partes interessadas. O Conselho de Segurança tomará devida nota do não cumprimento dessas medidas.

Art $^{\circ} .41$ - O Conselho de Segurança decidirá sobre as medidas que, sem envolver o emprego de forças armadas, deverão ser tomadas para tornar efectivas as suas decisões e poderá instar os membros das Nações Unidas a aplicarem tais medidas. Estas poderão incluir a interrupção completa ou parcial das relações económicas, dos meios de comunicação ferroviários, marítimos, aéreos, postais, telegráficos, radioeléctricos, ou de outra qualquer espécie, e o rompimento das relações diplomáticas.

$\mathrm{Art}^{\circ} .42$ - Se o Conselho de Segurança considerar que as medidas previstas no $\mathrm{Art}^{\circ} .41$ seriam ou demonstraram ser inadequadas, poderá levar a efeito, por meio de forças aéreas, navais ou terrestres, a acção que julgar necessária para manter ou restabelecer a paz e a segurança internacionais. Tal acção poderá compreender demonstrações, bloqueios e outras operações, por parte das forças aéreas, navais ou terrestres dos membros das Nações Unidas. 


\section{O primeiro prescreve os meios pacíficos para a solução de controvérsias, através da}

$\mathrm{Art}^{\mathrm{o}} .43$ - Todos os membros das Nações Unidas se comprometem, a fim de contribuir para a manutenção da paz e da segurança internacionais, a proporcionar ao Conselho de Segurança, a seu pedido e em conformidade com um acordo ou acordos especiais, forças armadas, assistência e facilidades, inclusive direitos de passagem, necessários à manutenção da paz e da segurança internacionais.

Tal acordo ou tais acordos determinarão o número e tipos das forças, o seu grau de preparação e a sua localização geral, bem como a natureza das facilidades e da assistência a serem proporcionadas.

O acordo ou acordos serão negociados o mais cedo possível, por iniciativa do Conselho de Segurança. Serão concluídos entre o Conselho de Segurança e membros da Organização ou entre o Conselho de Segurança e grupos de membros e submetidos à ratificação, pelos Estados signatários, em conformidade com os respectivos procedimentos constitucionais.

$\mathrm{Art}^{\circ} .44$ - Quando o Conselho de Segurança decidir recorrer ao uso da força, deverá, antes de solicitar a um membro nele não representado o fornecimento de forças armadas em cumprimento das obrigações assumidas em virtude do $\mathrm{Art}^{\circ}$. 43, convidar o referido membro, se este assim o desejar, a participar nas decisões do Conselho de Segurança relativas ao emprego de contingentes das forças armadas do dito membro.

Art $^{\circ} .45$ - A fim de habilitar as Nações Unidas a tomar medidas militares urgentes, os membros das Nações Unidas deverão manter, imediatamente utilizáveis, contingentes das forças aéreas nacionais para a execução combinada de uma acção coercitiva internacional. A potência e o grau de preparação desses contingentes, bem como os planos de acção combinada, serão determinados pelo Conselho de Segurança com a assistência da Comissão de Estado-Maior, dentro dos limites estabelecidos no acordo ou acordos especiais a que se refere o $\operatorname{Art}^{\circ} .43$.

Art $^{\circ} .46$ - Os planos para a utilização da força armada serão elaborados pelo Conselho de Segurança com a assistência da Comissão de Estado-Maior.

Art $^{\circ} .47$ - Será estabelecida uma Comissão de Estado-Maior destinada a orientar e assistir o Conselho de Segurança, em todas as questões relativas às exigências militares do mesmo Conselho, para a manutenção da paz e da segurança internacionais, utilização e comando das forças colocadas à sua disposição, regulamentação de armamentos e possível desarmamento.

A Comissão de Estado-Maior será composta pelos chefes de estado-maior dos membros permanentes do Conselho de Segurança ou pelos seus representantes. Qualquer membro das Nações Unidas que não estiver permanentemente representado na Comissão será por esta convidado a tomar parte nos seus trabalhos, sempre que a sua participação for necessária ao eficiente cumprimento das responsabilidades da Comissão.

A Comissão de Estado-Maior será responsável, sob a autoridade do Conselho de Segurança, pela direcção estratégica de todas as forças armadas postas à disposição do dito Conselho. As questões relativas ao comando dessas forças serão resolvidas ulteriormente.

A Comissão de Estado-Maior, com a autorização do Conselho de Segurança e depois de consultar os organismos regionais adequados, poderá estabelecer subcomissões regionais.

Art $^{\circ} .48$ - A acção necessária ao cumprimento das decisões do Conselho de Segurança para a manutenção da paz e da segurança internacionais será levada a efeito por todos os membros das Nações Unidas ou por alguns deles, conforme seja determinado pelo Conselho de Segurança.

Essas decisões serão executadas pelos membros das Nações Unidas directamente e mediante a sua acção nos organismos internacionais apropriados de que façam parte.

Art $^{\circ} .49$ - Os membros das Nações Unidas associar-se-ão para a prestação de assistência mútua na execução das medidas determinadas pelo Conselho de Segurança.

$\mathrm{Art}^{\circ} .50$ - Se um Estado for objecto de medidas preventivas ou coercitivas tomadas pelo Conselho de Segurança, qualquer outro Estado, quer seja ou não membro das Nações Unidas, que enfrente dificuldades económicas especiais resultantes da execução daquelas medidas terá o direito de consultar o Conselho de Segurança no que respeita à solução de tais dificuldades.

$\mathrm{Art}^{\circ} .51$ - Nada na presente Carta prejudicará o direito inerente de legítima defesa individual ou colectiva, no caso de ocorrer um ataque armado contra um membro das Nações Unidas, até que o Conselho de Segurança tenha tomado as medidas necessárias para a manutenção da paz e da segurança internacionais. As medidas tomadas pelos membros no exercício desse direito de legítima defesa serão comunicadas imediatamente ao Conselho de Segurança e não deverão, de modo algum, atingir a autoridade e a responsabilidade que a presente Carta atribui ao Conselho para levar a efeito, em qualquer momento, a acção que julgar necessária à manutenção ou ao restabelecimento da paz e da segurança internacionais. 
negociação, mediação, conciliação e/ou arbitragem. O segundo abre a possibilidade do uso da força na aplicação de medidas para a resolução de conflitos que se tornaram de fato uma ameaça à paz e segurança internacional.

Em 1950, diante da crise da Coréia a Assembléia Geral da ONU viu-se obrigada a criar medidas que suprissem as deficiências do Sistema das Nações Unidas em lidar diretamente com situações de conflito, não obstante o estabelecido no artigo 43 da Carta, e da inexistência de acordos especiais entre os Estados Membros e o Conselho de segurança. Nesses termos, em 25 de junho de 1950, mesmo com a ausência da União Soviética, o Conselho de Segurança qualificou a invasão da Coréia do Sul por tropas da Coréia do Norte como ato de ruptura da paz. Em 07 de junho no ano seguinte o Conselho de Segurança agradeceu a acolhida às suas recomendações por parte de vários Estados, aceitou que o comando das forças de paz fossem entregues aos Estados Unidos e autorizou as operações sob a bandeira da ONU. No entanto, no retorno do representante da União Soviética ao seu lugar no Conselho de Segurança, usou este de seu direito de veto sobre as operações militares que já haviam se iniciado na Coréia com o emprego de forças armadas. Tal situação foi considerada um flagrante exemplo de falha do Conselho de Segurança (e do sistema da ONU) ${ }^{96}$.

Com o passar dos anos, as experiências bem ou mal sucedidas da ONU na implementação das operações de paz permitiram que se pudessem consolidar regras fundamentais sobre as operações de paz:

(i) Manutenção do controle das operações na ONU;

(ii) Autorização expressa entre os Estados envolvidos, ou seja, deve haver um "consentimento para a legitimidade";

\footnotetext{
${ }^{96}$ MÓDULO DE PAULA, Luiz Augusto, Genocídio e o Tribunal Penal Internacional para Ruanda, São Paulo, 2012, Pág. 45
} 
(iii) Caráter voluntário de participação por parte dos Estados Membros;

(iv) Conveniência na universalidade da composição dos efetivos;

(v) Imparcialidade no cumprimento do mandato;

(vi) Uso da força como ultima ratio regis e apenas como legítima defesa e

(vii) Posse restrita de armamentos pelo pessoal envolvido na operação.

Essa doutrina viria a sofrer necessárias modificações com o reconhecimento e implementação de políticas distintas, mas absolutamente complementares, representadas pelo Relatório Brahimi, aprovado pela Assembléia Geral e pelo Conselho de Segurança. De acordo com os estudos levados a efeito no Painel que elaborou o referido relatório, o consentimento das partes envolvidas, a imparcialidade e o uso da força apenas como instrumento de legítima defesa continuam sendo os pilares das operações de manutenção da paz; ao mesmo tempo, assinala a necessidade de correção de falhas na relutância em distinguir politicamente o agressor da vítima, situação que causou danos à credibilidade das Nações Unidas na década de 90.

Com o fim da guerra fria e a dissolução da União Soviética verificou-se a necessidade da adopção de uma nova postura por parte do Conselho de Segurança em relação aos atos de violência, em especial aos atos de ruptura da paz e segurança internacionais.

De acordo com Alan James, a operação de paz pode ser definida como uma atividade secundária em que as partes no conflito, os responsáveis pelos aspectos políticos e os responsáveis pela execução da operação no campo dependem uns dos outros tanto para o estabelecimento, quanto para o eventual êxito da operação. Ela não pode representar, portanto, ameaça para as partes no conflito, nem ser percebida como 
tal, decorrento desse fato a restrição ao uso da força, e tem de ser executada com rigorosa imparcialidade, sem o que seus participantes seriam vistos como partes no conflito e não mais como terceiros capazes de contribuir para o seu equacionamento ${ }^{97}$.

Em definição proposta pelo manual da International Peace Academy, a Operação de paz é a prevenção, a contenção, a moderação e o término de hostilidades entre Estados ou no interior de Estados, pela intervenção pacífica de terceiros, organizada e dirigida internacionalmente, com o emprego de forças multinacionais de soldados, policiais e civis, para restaurar e manter a paz $^{98}$.

As duas definições são um começo para se começar a pensar no que são as operações de paz, mas sozinhas não conseguem dar uma explicação, na medida em que a primeira se limita a falar da importância de se marcar a imparcialidade e a posição de terceiro. E a segunda fala das modalidades de operações de paz e em coincidência com a primeira definição, menciona a necessária natureza de imparcialidade.

Já Marrack Goulding define as operações de paz como um campo de operações estabelecidas pelas Nações Unidas com o consentimento das partes envolvidas para ajudar a controlar e resolver conflitos entre elas, sob o comando e o controle das Nações Unidas onde as despesas são pagas coletivamente pelos estados membros que contribuem voluntariamente com pessoal e equipamentos militares, agindo imparcialmente entre as partes e usando a força em uma extensão mínimamente necessária ${ }^{99}$.

\footnotetext{
${ }^{97}$ JAMES, Alan, Peacekeeping in international politics, apud, SENA CARDOSO, Afonso José, O Brasil nas operações de paz das Nações Unidas, Brasília, Instituto Rio Branco, 1998. Pág. 17

${ }^{98}$ SENA CARDOSO, Afonso José, O Brasil nas operações de paz das Nações Unidas, Brasília, Instituto Rio Branco, 1998. Pág. 17.

${ }^{99}$ GOULDING, Marrack. The evolution of United Nations Peacekeeping. In: International Affairs, vol. 69, n³ 3, 1993, Pág. 445.
} 
Para William Durch as operações de paz são esforços civil-militares multilaterais, autorizados internacionalmente para promover e proteger transições da guerra para a paz ${ }^{100}$.

Sozinhas as diferentes definições apresentam pequenas dificuldades ao entendimento do que sejam as operações de paz, a definição de Marrack Goulding, como defende Alex Bellamy, peca por desconsiderar a possibilidade das operações não serem realizadas no âmbito das Nações Unidas. No mais, as definições acima podem ser consideradas complementares, na medida em que falam da natureza civil, militar e multilateras das operações, que estas são realizadas para promover transições da guerra para a paz, falam da imparcialidade que deve permear e transparecer das operações, e da sua natureza de preventiva e moderativa. Ou seja, demonstram de modo sucinto em que consistem as operações de paz.

De acorco com José Sena Fontoura ${ }^{101}$, as operações de paz têm sido empregadas em atividades tão diversas como a observação de cessar fogo, de retiradas de tropas ou da redução negociada de armamentos, e a supervisão de eleições. $\mathrm{O}$ autor chama atenção para o fato de que, para que a operação seja considerada imparcial, quando se assumem funções de manutenção da lei e da ordem, em um conflito de natureza interna, seja importante que a operação da paz se dê em nome de um governo, ou em apoio a un conjunto de arranjos constitucionais, amplamente aceitos como legítimos na jurisdição em questão.

Ainda de acordo com o mesmo autor, parafraseando Alan James ${ }^{102}$, para que estas sejam consideradas eficazes precisam:

\footnotetext{
${ }^{100}$ CHURCH, William, Apud, Bellamy, Alex, J. (et al), Op. Cit. Pág.19.

${ }^{101}$ SENA CARDOSO, José Pena, Op. Cit,. Pág. 17.

102 JAMES Alan, Op. Cit, Apud, SENA Cardoso, Op. Cit. Pag. 18.
} 
(i) Ser estabelecidas em um amplo marco internacional,

(ii) Apoiar-se em mecanismo claros e aceitos para a cessão de pessoal e correspondente reembolso,

(iii) Contar com o consentimento expresso do Estado ou Estados anfitriões, e

(iv) Lograr assegurar a efetiva cooperação política das partes no conflito.

Ainda de acordo com José Fontoura, coincidentemente também para James Boyd $^{103}$ os elementos de uma operação de paz devem ser:

(v) Uma presença militar ou quase-militar internacional (para o autor o caráter predominantemente militar das operações de paz não decorreria tanto da natureza da atividade, quanto da participação majoritaria dos militares. Esta por sua vez seria consequência da sua maior e mais pronta disponibilidade para mobilização, sua melhor interação com os responsáveis pelas ações militares das partes em conflito, o hábito da disciplina, a familiaridade com procedimentos importantes na contenção de conflitos e com o exercicio da autoridade),

(vi) O Consentimento dos anfitriões e dos que contribuem com pessoal para a operação,

(vii) O Objetivo de prevenir ou conter a violência,

(viii) O Uso limitado da força para a consecução desse objetivo, e

(ix) A Tentativa de criar as condições e o ambiente mais favorável para a solução pacífica do conflito e das diferenças a ele associadas.

103 BOYD, James, United Nations Peacekeeping Operations: A military and political appraisal, apud, SENA Cardoso, Op. Cit. Pág. 18. 
Dessa forma, o autor conclui que as operações de paz são simplesmente uma técnica ou um instrumento de administração por terceiros de conflitos entre Estados ou no território de um determinado Estado, por meio da intervenção internacional nãoviolenta, voluntária, organizada e preferívelmente de caráter multinacional, pautada pela imparcialidade, consentida pelo Estado ou Estados anfitriões e desejada e apoiada pelas partes em conflito.

Esse instrumento ou técnica não parece ter evoluído como um sistema de segurança coletiva de observação mandatória, nem como parte integrante de um sistema com tais finalidades e características. Por outro lado, não substitui a negociação, nem os esforços voltados à promoção da paz, para as quais poderá eventualmente contribuir já que tem, efetivamente como objetivo, favorecer com sua existência o desenvolvimento de entendimentos negociados para a solução ou superação de conflitos.

Em Uma Agenda para a Paz ${ }^{104}$, relatório do Secretário-Geral da ONU Boutros Ghali, este procurou uniformizar os conceitos relacionados à ação internacional para prevenção e resolução de conflitos. Para isso, fez análises e recomendações sobre as formas de fortalecer e tornar mais eficiente, dentro do quadro e das disposições da Carta, a capacidade das Nações Unidas para a diplomacia preventiva, a promoção da paz, a manutenção da paz. No relatório, o Secretário-Geral afirma que a soberania, a integridade dos Estados, e a manutenção da paz constituem a pedra fundamental da Organização, chama a atenção para as rápidas mudanças econômicas, sociais e políticas que ocorriam à época, que afetavam os Estados, a Comunidade Internacional e sua relação com a paz e a segurança internacionais.

\footnotetext{
104 A/RES/47/277 - S/24111 (An Agenda for Peace. Preventive diplomacy, peacemaking and peacekeeping). Nova York: Nações Unidas, 17 de junho de 1992 e A/RES/50/60 - S/1995-1 (Supplement to An Agenda for Peace). Nova York: Nações Unidas, 3 de janeiro de 1995
} 
O relatório, então, apresenta e classifica por fases (embora na prática nem sempre seja realizadas por fases), as atividades desenvolvidas pela ONU, no campo da paz e segurança internacionais, em cinco categorias:

(i) A diplomacia preventiva, foi definida como ações para evitar o surgimento de disputas ou sua evolução em conflitos e para conter a escalada destes em conflitos maiores e mais complexos que seus próprios limites. Missões preventivas poderiam incluir o emprego de tropas (preventive deployment), por solicitação das partes, $\mathrm{Na}$ atualidade, praticamente não se registra o emprego de tropas com função preventiva e a atividade é desempenhada pelo próprio Secretário-Geral e seus Enviados Especiais ou por missões políticas. Inclui ações como missões de monitorização e verificação (factfinding) e bons ofícios;

(ii) O Peacemaking (promoção da paz) considerado como o ato de conduzir as partes hostis, a acordo, através do uso de meios pacíficos de solução de litígios, como os que estão previstos no Capítulo VI da Carta. O relatório incluiu em peacemaking, as peace-enforcement units para conter violações de cessar-fogo, que poderiam ser empregadas, teoricamente, sem autorização das partes em conflito. O conceito de imposição da paz foi testado, sem muito sucesso na Somália (UNOSOM II);

(iii) Peace-enforcement (imposição da paz) é a intervenção diretamente no país ou entre as partes em conflito, sem a autorização destas ou do país em que ocorre o conflito.

(iii) O Peacekeeping (manutenção da paz) como a efetiva presença das Nações Unidas em campo, com o expresso consentimento das partes envolvidas, envolvendo tanto um efetivo militar, quanto policial e civil. O peacekeeping é apresentado como 
uma técnica que aumenta tanto as possibilidades de prevenção quanto de realização da paz.

As características essenciais de uma operação da paz tradicional são neutralidade, consentimento e uso mínimo da força. Estas operações de paz tradicionais são utilizadas há mais de 50 anos pelas Nações Unidas e seu objetivo primário é fazer cessar a situação de ruptura da paz e, atingido este objetivo, oferecer condições e meios para que se mantenha a paz, como se verá mais adiante.

Já Alex Bellamy ${ }^{105}$ defende a existência de sete tipos de operações de paz, que ao serem analisados, podem ser considerados desdobramentos dos tipos comumente empregues na doutrina. De acordo com o mesmo autor, tal distinção é feita tendo por base os objetivos a alcançar na finalidade de cada tipo de missão, ao invés de se basear nos meios empregados para tal. E são os seguintes tipos:

(i). Diplomacia preventiva (preventive deployments) - geralmente conduzida com o consentimento do Estado anfitrião, as operações preventivas implementam a manutenção de paz de forma a prevenir tanto o surgimento de conflitos violentos em um primeiro momento, quanto a materialização de uma ameaça especifica contra a população civil.

(ii). Operação de manutenção de paz tradicional (Traditional Peacekeeping) Estas operações tinham por intenção apoiar a manutenção da paz entre os Estados através da criação de um espaço politco no qual os Estados beligerantes negociassem soluções politicos. As operações de paz tradicionais tem lugar no espaço entre o acordo de cessar fogo e a conclusão do acordo político. Operações de manutenção da paz tradicionais não propõem ou forçam soluções

\footnotetext{
${ }^{105}$ BELLAMY, Alex J., Op. Cit. Pág. 08.
} 
politicas particulares, ao contrário, trabalham com o consentimento dos beligerantes e tentam construir a confiança necessária à facilitação do diálogo político.

(iii). Operações de paz mais amplas (Wider peacekeeping) - estas operações têm por intenção preencher as lacunas das operações tradicionais, assim como realizar certas tarefas adicionais, como levar certo "alivio humanitario" num contexto de conflito. Se desenvolveram como uma resposta ad hoc para os términos de cessar fogo ou acordos politicos .

(iv). Imposição da paz (Peace enforcement) - Estas operações impõem a decisão do Conselho de Segurança da ONU às partes em conflito. As operações de imposição da paz são a manifestação mais próxima do papel de segurança coletiva originalmente previsto para a ONU pelos autores da sua Carta.

(v). Transições assitidas (Assisting transitions) - Estas operações multidimensionais involvem o estabelecimento de militares, policias e civis para assistir as partes na implemntação do um acordo politico ou na transição de uma paz pesadamente suportada por agencias internacionais, para uma paz autosustentada. Estas operações têm lugar depois que o cessar fogo e o acordo político são realizados.. O mandato de operações transicionais geralmente gira em torno da implementação de acordos de paz.

(vii). Administração transicional (Transitional administrations) - Estas também são operações multidimensionais estabelecidas depois dos acordos de paz, mas se distinguem por assumirem a autoridade soberana em territorio particular. Para além de manter a paz, proteger civis, realizar acordos de paz, as administrações transicionais têm a autoridade de fazer e forçar o cumprimento da lei, exercer 
controle sobre os aspectos econômicos, regular a mídia, as fronteiras, as escolas, os hospitaos, os transportes e o sistema judicial.

(vii). Operações de apoio à paz (Peace suport operations) - estas são desenhadas para ajudar a estabelecer a paz pós-Westfaliana. Ou seja, almejam o estabelecimento de um sistema politico democratico e liberal.

Vale fazer menção ao fato de existirem atividades comuns ao processo de consolidação da paz, que constituem importante fator no sucesso da mesma, na prevenção de conflitos, especialmente em países institucionalmente fracos. Essas atividades geralmente figuram nos objetivos das operações de manutenção da paz e são as seguintes ${ }^{106}$ :

(i) Os Programas de DDR (Desarmamento, Desmobilização e Reintegração de ex-combatentes), que geralmente fazem parte de operações realizadas em países que sofrem conflitos intra-estatais.

(ii) Reforma do setor de segurança - esta medida é aplicada em situação de pósconflito e consiste na reestruturação dos sistemas de defesa e policial e pode incluir também a reforma do setor carcerário e adminsitração de justiça transitória. A Reforma do setor de segurança está intimamente relacionada a elementos de consolidação da paz, como o restabelecimento do Estado de Direito, mediante reforma legal e judicial, combate à impunidade e estabelecimento de mecanismos de proteção e promoção dos direitos humanos. A Reforma do Setor de Segurança geralmente envolve a incorporação ou o afastamento das partes envolvidas no conflito, nas Forças

106 NEVES, Gilda Motta Santos, Comissão das Nações Unidas para Consolidação da Paz: perspectiva brasileira, Brasília, FUNAG, 2009, Pág. 54. 
Armadas do respetivo país de forma reduzir o número de integrantes, sem ferir susceptibilidades.

(iii) Estado de Direito e Justiça - o estabelecimento deste se encontra relacionado à reforma do setor de segurança, na medida em que trata-se de estabelecer o quadro institucional e político para prevalência da lei e da ordem. Pode incluir a reforma constitucional e se incluir na "justiça de transição".

Já no Relatório Brahimi ${ }^{107}$, o elemento de construção da paz é apresentado como um conjunto de atividades levadas a efeito na zona de conflitos, tendentes à reconstrução das bases da paz e fornecendo instrumentos para que estas bases signifiquem algo mais que simplesmente a ausência da guerra. Vale dizer que o Relatório foi proposto por Kofi Annan como uma ampla revisão das atividades da ONU relacionadas à paz e à segurança, com a finalidade de enfrentar os novos desafios que surgiam na conjuntura internacional em relação às operações de manutenção da paz. $\mathrm{O}$ Relatório consolidou os novos entendimentos relacionados ao consentimento das partes no envio da missão, à imparcialidade da missão em relação ao conflito e seus motivos e à autodefesa (possibilidade do uso da força). O relatório sugere, ainda, missões mais equipadas e menos simbólicas.

Assim, as operações com elementos de construção da paz podem comportar, por exemplo: a recondução dos refugiados aos seus lares, a inserção de ex-combatentes na sociedade civil, a reconstrução da ordem através do treinamento da polícia e, o fornecimento de assistência técnica para promoção do desenvolvimento da democracia, tal como auxílio em processos eleitorais, a promoção de técnicas de negociação e mediação e a assistência na promoção de entidades de direitos humanos. O relatório,

107 A/55/305-S/2000/809 - Relatório do Grupo para as Operações de Paz da ONU. 
inclui ainda, entre os elementos das operações de construção da paz o apoio ao combate à corrupção e a implementação de programas humanitários ${ }^{108}$.

O Relatório Brahimi foi dividido em seis capítulos que contemplam todos os aspectos das operações de paz. O primeiro capítulo apresenta as razões pelas quais necessitam as operações de paz uma mudança estrutural e até mesmo filosófica; o segundo, cuida dos aspectos relacionados à doutrina, estratégia e processo decisório para as operações de paz; o terceiro, analisa a capacidade das Nações Unidas em estabelecer operações, mobilizar e empregar seu pessoal de forma mais rápida e efetiva; o quarto capítulo analisa as questões relativas à infra-estrutura de planejamento e suporte das operações; o quinto capítulo preocupa-se com a difusão de informações em termos tecnológicos, revelando uma preocupação de inserção das operações de paz e das informações ali geradas no dinâmico universo da internet; finalmente, o sexto e último capítulo cuida dos desafios da implementação das recomendações feitas pelo relatório (os estudos levados a efeito em cada capítulo conduzem a recomendações específicas), cujo objetivo é tornar as operações de paz efetivas na exata medida de sua credibilidade e legalidade $^{109}$.

De acordo com Paulo da Fontoura ${ }^{110}$, são três os órgãos das Nações Unidas envolvidos diretamente com as operações de paz: a Assembléia Geral, através do Comitê Especial da Assembléia-Geral sobre as Operações de Paz, o Secretariado, através do Departamento de Operações de Paz e do Departamento de Relações Políticas, além do próprio Conselho de Segurança, onde se estabelecem comissões de acompanhamento de cada uma das operações em andamento. Paralelamente, discussões

\footnotetext{
108 MÓDULO, Luiz de Paula, Op. Cit, Pág. 50.

${ }^{109}$ Ibidem.

${ }^{110}$ FONTOURA, O Brasil e as Operações de Manutenção da Paz nas Nações Unidas, Instituto Rio Branco, Brasília, 2005, Pág. 109.
} 
acerca das operações de paz são travadas nos Comitês que assessoram a Assembléia Geral, com especial referência ao I Comitê - Desarmamento e Segurança Internacional e ao IV Comitê - Política Especial e Descolonização.

O Comitê Especial da Assembléia-Geral sobre as Operações de Paz foi criado pela Assembléia através da Resolução A/RES/XIX/2006 de 1964, com fundamento no Artigo 22 da Carta. Seu objetivo, é fazer uma avaliação abrangente de toda a questão das operações de manutenção da paz em todos os seus aspectos. O mesmo autor destaca a importância desse Comitê, como um foro que deve permitir a aproximação daqueles que denomina "principistas" (defensores ortodoxos dos princípios da não-intervenção e soberania), e os "vanguardistas" (aqueles dispostos a rever os conceitos de nãointervenção e soberania), sob pena de esvaziamento do próprio Comitê e da Assembléia Geral como órgão afeto às operações de paz. Finalmente, deve-se destacar que o Comitê tem suas reuniões na sede da ONU entre abril e maio, a partir das quais são apresentadas suas recomendações à Assembléia Geral que as aprova por resolução.

O Departamento de Operações de Paz foi criado pelo Secretariado Geral em 1992 e institucionalizado em 1993, sob a direção de um sub Secretário-geral. Desde 1999, o pessoal a trabalho no Departamento de Operações de Paz faz parte dos quadros da Organização, situação diversa daquele vivida anteriormente pelo departamento, cujo pessoal era composto de militares temporariamente cedidos pelos Estados Membros, sem ônus à Organização. É função do Departamento de Operações de Paz coordenar o orçamento das operações de paz, que é aprovado na Assembléia Geral por recomendação do Comitê Especial da Assembléia-Geral sobre as Operações de Paz, bem como solicitar, organizar e comandar o emprego de pessoal, civil ou militar, armado ou não, nas operações autorizadas pelo Conselho. 
Finalmente, no Conselho de Segurança cada operação de paz suscita a criação de uma comissão de acompanhamento, cuja função é proporcionar a mais completa interação entre o Conselho e o Secretariado, a quem está vinculado com o Departamento de operações da paz.

A composição dos recursos humanos que integram as forças de paz, chamados de "capacetes azuis", está definida no artigo 43 da Carta da ONU, de acordo com o qual os Estados Membros se comprometem a proporcionar ao Conselho de Segurança "forças armadas, assistências e facilidades, incluindo direito de passagem, necessários para a manutenção da paz e da segurança".

O financiamento das operações de paz constitui um aspecto bastante polêmico, já que tais operações não são atividades integradas às funções regulares da ONU, como as Agências Especializadas, os Programas e os Fundos da organização. Esta característica impede que os recursos sejam otimizados e destinados especificamente às operações de paz.

Existe uma escala de financiamento das operações de paz de acordo com a qual os cinco membros permanentes do Conselho de Segurança ficaram responsáveis por $55 \%$ do custo total das operações; os países desenvolvidos por contribuições iguais às parcelas de sua responsabilidade no orçamento regular da ONU; os países em desenvolvimento por cerca de $20 \%$ do que contribuem regularmente e os países pobres por apenas $10 \%$ de sua cota regular. Adicionalmente, cada operação de paz possui uma conta especial onde são depositados os recursos captados em outras fontes (instituições financeiras internacionais, por exemplo) ${ }^{111}$.

\footnotetext{
${ }^{111}$ BIGATÃO, Juliana de Paula Bigatão, As Operações de Manutenção da Paz das Nações Unidas no pósGuerra Fria: o caso dos conflitos armados intra-estatais, Pág. 03
} 
As contribuições financeiras às Missões de Paz, tanto dos Estados-membros, quanto de outras instituições e organizações internacionais, são muitas vezes vistas como um fardo, já que o sucesso de tais intervenções não pode ser previsto. Isso reflete diretamente na decisão de se instituir ou não uma nova operação e até mesmo de manter as já existentes.

Em linhas gerais, os países foram distribuídos em quatro categorias de países: Grupo A, composto pelos Membros permanentes, que passaram a constituir uma categoria específica que, além de pagar quotas de percentual idênticas às quotas para o orçamento, respondem pelos descontos conferidos aos países dos grupos $\mathrm{C}$ e $\mathrm{D}$, devido a suas "responsabilidades especiais"; Grupo B, países desenvolvidos, que pagam o mesmo percentual calculado para o Orçamento Regular; Grupo C, países em desenvolvimento, que contribuem com $20 \%$ do percentual pago para o Orçamento Regular; e Grupo D, países de menor desenvolvimento relativo, que contribuem com $10 \%$ do percentual pago para o Orçamento Regular. O objetivo dessa iniciativa era prover a ONU de um sistema de coleta de fundos em bases estáveis e previsíveis. Não fosse assim, a criação de operações de manutenção da paz ficaria mais sujeita à boa vontade dos principais países contribuintes em fornecer financiamento do que condicionada por ameaças à paz e segurança internacionais ${ }^{112}$.

Durante a Guerra Fria, as missões da ONU seguiram, o padrão de missões de observação militar voltadas ao monitoramento ou supervisionamento de cessar-fogos, tréguas e limites de fronteiras em áreas conflituosa. A partir de 1988, as missões das Nações Unidas passaram a ter ambições mais vastas. Para além da tradicional separação das partes em confronto, pedia-se, a estas missões, que se ocupassem com tarefas relacionadas com a recuperação das instituições do estado; a preparação de eleições

\footnotetext{
${ }^{112}$ FONTOURA, Paulo, Op. Cit., Pág.74.
} 
livres; a distribuição de ajuda; a desmilitarização dos combatentes, o seu acantonamento e desarmamento.

Como acima mencionado, as primeiras operações de manutenção da paz da ONU foram autorizadas sob a égide da Guerra Fria, período em que a rivalidade ideológica entre Estados Unidos e União Soviética influenciou consideravelmente o comportamento dos demais Estados do sistema internacional. Neste contexto, a maioria dos conflitos envolvia essencialmente unidades soberanas, opondo dois ou mais Estados dispostos a garantir seus objetivos nacionais e preservar seu território contra a agressão externa. Os aparatos militares eram bem definidos e a guerra poderia ser entendida como um conflito entre forças armadas de dois ou mais Estados.

As operações de manutenção da paz clássicas ou de primeira geração vigoraram até o final da década de 1980, e durante este período foram colocadas em execução 13 missões, compostas tanto por pessoal desarmado (forças de observação), como por tropas armadas (forças de paz). O baixo número de missões operacionalizadas neste período, longe de significar uma diminuição dos conflitos internacionais, representa a paralisia do Conselho de Segurança durante a Guerra Fria devido à falta de consenso entre seus membros permanentes. Além dos problemas da mobilização e do financiamento das tropas, as operações de manutenção da paz "clássicas" enfrentaram contradições em seus princípios de consenso, imparcialidade e recusa ao uso da força. Muitas vezes, o cumprimento das funções e das tarefas designadas nos mandatos das operações de manutenção da paz não se mostra viável nesse quadro de princípios. A UNFICYP (Força de Manutenção da Paz das Nações Unidas no Chipre), por exemplo, estabelecida em março de 1964 para evitar hostilidades entre as comunidades grega e turca, sob o princípio de não uso da força, nada pôde fazer frente a violenta carnificina instaurada pelas facções rivais dessas comunidades. No Congo, as tarefas determinadas 
para a ONUC (Operação das Nações Unidas no Congo - 1960-1964), que vieram a incluir a assistência na manutenção da ordem publica e governamental, exigiram a autorização, pelo Conselho de Segurança, do uso da força além da legítima defesa, afim de evitar a guerra civil e expulsar as forças mercenárias.

Com o final do conflito bipolar inaugurou-se o período de maior atuação da ONU no campo da manutenção da paz e segurança internacional. Entre 1988 e 1999 foram instituídas 40 operações de manutenção da paz, ou seja, o total de missões triplicou em relação às quatro décadas anteriores.

No entendimento de Paulo Fontoura ${ }^{113}$, os principais fatores que influenciaram a grande proliferação das missões de manutenção da paz neste período são: o ressurgimento de tensões que se supunham superadas, como os conflitos de fundo étnico, religioso ou nacionalista; o maior apoio das grandes potências às atividades da ONU no campo da manutenção da paz e segurança; e a "crescente universalização dos valores da democracia e do respeito aos direitos humanos".

Neste contexto, os conflitos intra-estatais de dimensões política, étnica, religiosa e cultural se evidenciaram no seu desborde ao cenário internacional, desafiando cada vez mais a capacidade das Nações Unidas em definir o que representa uma ameaça à paz e segurança, assim como impondo vários obstáculos aos princípios tradicionais das operações de paz.

Ao invés da distinção entre as operações clássicas de operações de paz, Alex Bellamy divide as diferenças Westfalianos e pós-Westfaliano. Para o primeiro, a principal função das operações de paz é auxiliar a resolução pacifica de disputas entre Estados. Nessa perspectiva, a conduta, a organização politica dos Estados ou a relação

\footnotetext{
${ }^{113}$ FONTOURA, Paulo, Op. Cit. Pág 83.
} 
entre Estado e sociedade não era da preocupação dos peacekeepers, desde que os Estados houvessem subscrito as normas westfalianas de soberania, autonomia e não ingerência nos assuntos internos dos Estados.

Em contraste, a concepção pós-Westfaliana sugere que, a longo prazo relações pacificas entre Estados requerem regimes democráticos liberais e a participação da sociedade. A paz doméstica e a forma como o Estado conduz as relações internacionais está intrinsecamente ligada à natureza do seu sistema politico e da sua sociedade. Os proponentes desta visão geralmente argumentam que os estados têm a responsabilidade de proteger a população de genocidios, crimes de guerra, crimes contra a humanidade e limpezas étnicas e quando falham manifestamente em fazê-lo cabe à sociedade internacional o dever de proteger a população vulnerável. Consequentemente o papel das operações de paz pós-westfalianas não se limita à manutenção da ordem entre os Estados, antes pelo contrário toma para si uma tarefa mais ambiciosa de promover e por vezes impôr a paz, segurança e a reconstrução politica, intitucional, social e econômica nos Estados. O foco muda de entre paises para no próprio país. Ou seja, Ao invés de se limitar aos conflitos entre fronteiras, as operações de paz, cada vez mais são realizadas no seio dos próprios paises, seja em conflitos com outros paises ou em conflito interno.

O debate sobre as concepções Westfaliana e pós-Westfaliana das operações de paz traz à tona uma questão que se considera refletir uma tensão na Carta das Nações Unidas sobre se dever priorizar a segurança dos Estados ou das pessoas. Reflete, ainda, as diferentes preocupações sobre a legitimidade das operações de paz e a abrangência das autoridades multilaterais frente à autoridade soberana. Tal debate também revela as diferentes ideias sobre como promover da melhor maneira possivel, a paz e segurança internacionais. Embora o debate não seja conclusivo, o pêndulo oscila em favor da concepção pós-Westfaliana, como demonstra a atitude de mais de 150 Estados- 
membros das Nações Unidas no final de 2005, ao reconhecerem a sua responsabilidade em proteger os seus cidadãos de genocidios e atrocidades em massa e prometerem tomar medidas para prevenir tais crimes. Mais recentemente, no inicio de 2008 a ONU adotou um conjunto de principios e diretrizes para operações de paz que incluiram a proteção a civis como tarefa chave. Tudo isso sugere que tem crescido o apoio a principios básicos da visão pós-Westfaliana das operações de paz.

Independentemente do tipo que se defenda, verifica-se que ter havido uma evolução clara no quadro das operações de paz, que passaram de meras missões de observação, para missões com formatos e objetivos cada vez mais amplos.

As operações de paz podem ser consideradas como um mecanismo de justiça de transição por excelência, na medida em que, mesmo não se encontrando no rol defendido pela doutrina, as atividades realizadas no âmbito das operações de paz coincidem em grande parte com as modalidades de justiça de transição, principalmente considerando-se os desdobramentos destas. Quando-se fala em reformas institucionais, na realização de programas de DDR, em suma as atividades de busca pela paz e recontrução do país, empreendidas pelas operações, encontram em larga escala, materialização na justiça de transição.

No caso da Guiné-Bissau, por exemplo, apesar das várias tentativas de reconciliação realizadas através de conferências e reuniões não se chegou a criar mecanismos de busca pela verdade, ou de investigação histórica. Não houve politica de reparação, na medida em que as indenizações dadas após o conflito limitaram-se às pessoas que haviam sofrido prejuizos econômicos, mas no âmbito das reformas institucionais, preconizadas pela justiça de transição, os avanços foram e são 
consideráveis, possibilitados, principalmente pela operação de manutenção de paz constituida pela ONU.

Se considerar-se que, a Justiça de Transição, tem um papel cada vez mais amplo e significativo na construção da paz, com efeitos práticos, como a reconstrução do Estado, que pode se dar através da realização de reformas institucionais, a remoção dos perpetradores de cargos politicos, a realização de atividades de DDR (Desarmamaento, desmobilização e reintegração), a restauração da confiança nas instituições estatais, a consolidação da democracia, a criação de museus como forma de confrontar o passado e não permitir o seu esquecimento são algumas das atividades relacionadas ao tema. Então pode-se considerar que as atividades realizadas no âmbito das operações de paz, dependendo da sua natureza, podem enquadra-se no âmbito da justiça de transição ou ainda, que as operações de paz, são um método multifacetado e abrangente de colocar em pratica a justiça de transição.

3.1. As Operações de paz da Guiné-Bissau: UNOGBIS - UNIOGBIS (Apartir de 1999), e ECOMOG (1999).

A ECOMOG - The Economic Community of West African States Monitoring Group - foi uma força multilateral oeste Africana estabelecida pela Comunidade Econômica dos Estados do Oeste da África (CEDEAO) - Grupo de Monitoramento da Comunidade Econômica dos Estados do Oeste da África - foi instituida por um protocolo denominado "Protocol on Mutual Defence Assistance" em Freetown, na Serra-Leoa em 29 de maio de 1981 e foi criada como um braço armado da CEDEAO, com o objetivo de fazer frente aos conflitos que surgiam na região. A ECOMOG 
representou a primeira tentativa credível de iniciativa de segurança regional desde que a Organização da Unidade Africana (OUA), havia tentado criar uma "Força InterAfricano de intervenção ${ }^{114,}$.

As Forças da ECOMOG foram utilizadas por duas vezes para controlar conflitos: na Serra Leoa em 1997 e na Guiné-Bissau em 1999. Quando a ECOMOG interveio na África Ocidental, a comunidade internacional assistiu a uma grande evolução nos assuntos inter-africanos. Vários países africanos apoiaram a elaboração de um sistema coletivo regional com capacidade para responder a conflitos em vez de depender de uma força externa, como a ONU para intervir. As intervenções da ECOMOG marcaram um ponto de viragem importante na prática de manutenção da paz das organizações regionais ou sub-regionais. Sua importância residia também no fato de que tinha reacendido um velho debate dentro da África sobre a criação de uma capacidade continental para responder a questões relacionadas com a paz e instabilidade $^{115}$.

A idéia de uma força de paz Africana para gerir os conflitos africanos foi proposta pela primeira vez pelo presidente Kwame Nkrumah do Gana, quando a OUA foi criada em 1963. Desde então, várias tentativas sem sucesso foram feitas para criar um corpo com capacidade para resolver conflitos no continente.

A Força Inter-Africana da OUA, criado em 1981 para monitorar a guerra civil no Chade, foi o primeiro exemplo prático de cooperação inter-Africana no campo da manutenção da paz, mas terminou em fracasso. Planejamento inadequado, a confusão sobre o mandato, a ausência de um comando da OUA e de uma estrutura de controle, o

\footnotetext{
114 ADEBAJO, Adekeyeo, 'Liberia's Civil War: Nigeria, ECOMOG, and Regional Security in West Africa,' Lynne Rienner/International Peace Academy, 2002, Pág.78

${ }^{115}$ ECOMOG: A model for Africa? Comfort Ero, Centre for Defence Studies, King's College, London, Building stability in Africa: Challenges for the new millennium, February 2000.
} 
mínimo de recursos financeiros e logísticos, e, acima de tudo, a falta de vontade política, e não apenas das partes no conflito, mas também de terceiros mediadores na região, contribuiu para o fracasso da primeira tentativa da OUA para enviar uma força de manutenção da paz no continente.

A intervenção da ECOMOG na Libéria, portanto, representou um divisor de águas na segurança coletiva Africano por um organismo regional ou sub-regional, na medida em que retomava o discurso da possibilidade de criação de um mecanismo africano de resolução de conflitos.

Entre 1991 e 1993, o Secretário-Geral da OUA, Salim Ahmed Salim começou a elaborar propostas para uma força de manutenção de paz continental que não era muito diferente da ECOMOG. Os debates no seio da OUA sobre a capacidade de gestão de conflitos e como construir um mecanismo de resposta refletiu os problemas que a CEDEAO acabou apresentando em relação à missões da ECOMOG. Outros organismos regionais como o Mercado Comum da África Oriental e Austral (COMESA), a Comunidade do Leste Africano (EAC), a Autoridade Inter-Governamental para o Desenvolvimento (IGAD) e da Comunidade de Desenvolvimento do Sul Africano (SADC), se debruçaram sobre os exemplos e experiência da CEDEAO para criar um aparato de segurança dentro de suas regiões. Estas organizações foram desenvolvidas principalmente para promover o desenvolvimento econômico e cooperação política. A idéia de que podiariam desempenhar um papel militar ou de segurança, já na época não parecia viável. No entanto os líderes africanos, à epoca aparentemente estavam interessados em construir um aparato de segurança dentro destas entidades subregionais, e principalmente operacionalizar a capacidade desses órgãos para intervir em conflitos regionais. Assim, em 1994, estados membros da SADC deram o passo 
decisivo de desempenhar o papel de pacificadores no Lesoto aquando das hostilidades entre o rei Letsie III, o Primeiro-Ministro, Mokhehle Ntsu e o Parlamento eleito.

Na Guiné-Bissau, após o fracasso na Libéria, a experiência da ECOMOG deveria ser uma oportunidade para provar que era uma força capaz e responsável na região. A mediação inicial para parar a luta foi essencialmente conduzida por Portugal e pelos ministros das Relações Exteriores da Comunidade dos Países de Língua Portuguesa (CPLP): Angola, Brasil, Cabo Verde, Moçambique e São Tomé e Príncipe. No entanto, o papel da CEDEAO havia sido tão decisivo que o acordo de paz foi assinado a 2 de Novembro, sob a égide da CEDEAO. Após a assinatura do acordo, a CEDEAO enviou uma força de interposição (ECOMOG) para monitorar o acordo de paz.

A operação da ECOMOG foi em grande parte liderada por países francófonos da região (Benin, Níger, Mali e Togo) e um país anglófono, a Gâmbia. Além disso, a operação foi apoiada logisticamente e financeiramente no âmbito da iniciativa de paz para os países africanos, Renforcement des capacités africaines maintien de la paix (Reforço da capacidade de manutenção de paz Africano - RECAMP). No entanto, as forças envolvidas foram retiradas de pequenos países com soldados inexperientes.

Essencialmente, no caso da Guiné-Bissau fazia-se necessária uma operação ao estilo de combate, mas os estados envolvidos não conseguiam fornecer o material logistico necessário. Para servir de exemplo, à ECOMOG faltava equipamento de rádio comunicação adequado não só para entrar em contato com as tropas dispersas pela Guiné-Bissau, mas também a com sede da ECOMOG. O surto de violência renovado em maio 1999, não só serviu para demonstrar que a ECOMOG não consegue evitar conflitos quando facções preferem a guerra à paz, mas também minou a credibilidade da 
CEDEAO em afirmar que a ECOMOG poderia garantir a segurança na região. Então, após assinatura do acordo de paz e marcação das eleições as tropas da ECOMOG se retiraram da Guiné-Bissau. As intervenções ECOMOG foram totalmente subscritas, não apenas por uma comunidade internacional que não podia mais encontrar soluções para os conflitos africanos, mas pelos africanos que queriam quebrar a dependência de assistência militar do exterior.

Em março de 1999 o Secretário Geral (S/1999/232), propõe ao Conselho de Segurança a criação de um Gabinete de apoio à consolidação da paz das Nações Unidas no país e determina que lhe seja confiado o seguinte mandato:

(i). Ajudar a criar um ambiente propício para restaurar e consolidar a paz, a democracia e o Estado de Direito e para a organização de eleições livres e transparentes;

(ii). Trabalhar com o Governo de Unidade Nacional, a CEDEAO e a ECOMOG, bem como com outros parceiros nacionais e internacionais para facilitar a implementação do Acordo de Abuja;

(iii). Buscar que o Governo e de outros partidos se comprometam a adotar um programa de recolha, eliminação e destruição voluntária de armas;

(iv). Proporcionar o quadro político e liderança para harmonizar e integrar as atividades do sistema das Nações Unidas no país, particularmente durante o período transitório até às eleições gerais presidenciais.

O pedido do secretario é confirmado pelo Conselho de Segurança por meio da Resolução: S/RES/1233 de 06 de abril de 1999 que determina que se estabeleçaum Gabinete de Apoio à consolidação da paz pós-Conflito na Guiné-Bissau (UNOGBIS), sob a liderança de um Representante do Secretário-Geral (S/1999/233), que irá proporcionar o quadro político e liderança para harmonizar e integrar as atividades do sistema das Nações Unidas na Guiné-Bissau durante o período de transição que 
conduzirá às eleições gerais presidenciais. O Gabinete irá também trabalhar em estreita cooperação com as partes interessadas, a CEDEAO, a ECOMOG bem como outras instituições nacionais e parceiros internacionais, na implementação do Acordo de Abuja;

O Relatório 456 de 4 de junho de 2004 - S/2004/456, trata da realização de reuniões de consenso entre os membros estatais para facilitar o contrutivo diálogo político em cursologue. A UNOGBIS organizou uma reunião, em 19 de Maio de 2004, entre o novo Governo, a Secretaria de Assembleia Nacional Popular e representantes da comunidade internacional, incluindo embaixadores acreditados em Bissau e representantes das agências das Nações Unidas. O encontro incentivou as novas autoridades a construir mais progressos sobre os progressos até então alcançados na normalização da situação política, em especial com base na fiel observância das disposições da Carta de Transição. A pedido do Chefe do Estado Maior das Forças Armadas, general Veríssimo Correia Seabra, a UNOGBIS, em estreita colaboração com a CEDEAO e parceiros bilaterais, iniciou o processo de planejamento da proposta de reforma das forças armadas. Com relação ao programa de reinserção, desmobilização e reintegração, o componente de reintegração está a decorrer bem e o Governo recebeu recursos adicionais do Banco Mundial para aumentar o número de beneficiários de 4327 a 7.376. No esforço contínuo de ajudar a reforçar a capacidade nacional para a proteção e respeito aos direitos humanos, a UNOGBIS ajudou a desenvolver um Plano de Ação Nacional dos Direitos Humanos. Este plano foi submetido ao Comitê Inter ministerial em março de 2004. A estrutura do Plano, que é composta de dois altos representantes de cada ministério, foi criada por iniciativa da UNOGBIS com vista à incorporação dos princípios dos direitos humanos no dia-a-dia do trabalho do governo. A Comissão deverá apresentar um plano final para a Assembleia Nacional Popular. A UNOGBIS 
tem procurado introduzir a educação em direitos humanos em todos os níveis do sistema educacional. A Universidade de Bissau, que está planejando fornecer cursos de direito, também está trabalhando com a UNOGBIS sobre a introdução de cursos de direitos humanos. A campanha de educação será centrado em um manual sobre direitos humanos, juntamente com um poster sobre a Declaração Universal dos Direitos Humanos, sendo que ambos serão elaborados e publicados em português pela UNOGBIS.

A UNOGBIS também tem continuado a promover a igualdade de gênero e a implementação da resolução 1325 (2000) do Conselho de Segurança sobre mulheres, paz e segurança. A eleição de uma mulher, Maria do Céu Silva Monteiro, como Presidente do Supremo Tribunal e a nomeação de cinco mulheres para postos ministeriais e o fato de constarem mais duas mulheres na Mesa da Assembleia Nacional Popular são desenvolvimentos encorajadores que mostram a crescente percepção por parte das autoridades nacionais do importante papel da mulher no processo político. Juntamente com outras entidades das Nações Unidas, a UNOGBIS continua a trabalhar com o Governo para a ratificação do Protocolo Facultativo à Convenção sobre a Eliminação de Todas as Formas de Discriminação contra a Mulher.

Relatório 969 de 14 de dezembro de 2004 - S/2004/969: Antes do motim de 06 de outubro, a UNOGBIS vinha fornecendo apoio técnico e recursos para o Governo. Isso permitiu ao Governo a criação de uma comissão preparatória para iniciar o processo de planejamento de um fórum onde iria discutir a reforma das forças armadas e da reconciliação entre as diversas facções dentro do corpo militar. As facções tendem a ter laços estreitos com distintas forças políticas, criando, dessa forma tensões dentro do estabelecimento militar. Dados os problemas em chegar a um entendimento comum 
sobre a iniciativa, e à relutância por parte das forças armadas a exercer os trabalhos da Comissão, foi decidido reavaliar o processo preparatório. Tal reavaliação foi interrompida pelos eventos de 06 de outubro e será retomada assim que uma nova liderança militar seja nomeada. Existe também a necessidade premente da reforma da polícia, que continua a enfrentar uma grave escassez de equipamentos, recursos e capacidades que lhe permitam cumprir o seu papel de segurança pública. Durante o período do relatório, a UNOGBIS e as agências das Nações Unidas têm continuado o seu trabalho de promover a igualdade de gênero e a implementação da resolução 1325 (2000) do Conselho de Segurança sobre a mulher, paz e segurança. Propõe a revisão do mandato da UNOGBIS. Esse novo papel irá permitir que o Gabinete trabalhe em estreita colaboração com a equipe das Nações Unidas de forma a integrar $o$ desenvolvimento com vista à definição de uma estratégia coesa de construção da paz a médio, imediato e longo prazos, a revisão do mandato da UNOGBIS vai permitir que o gabinete, trabalhando em conjunto com a equipe das Nações Unidas e da comunidade internacional, ajude a Guiné-Bissau a ultrapassar as suas dificuldades atuais, incluindo a organização de eleições presidenciais do próximo ano de forma a assegurar a plena restauração da normalidade constitucional. No que respeita às eleições, em resposta ao pedido do Presidente interino, a ONU está pronta para oferecer suporte técnico na sua organização e na coordenação da observação internacional. A UNOGBIS vai contribuir para institucionalizar a capacity building de forma a possibilitar que o legislativo, o executivo e o judiciário possam funcionar de forma mais eficaz. A Formação e advocacy no avanço do respeito pelos direitos humanos e do Estado de Direito será intensificado. Séria atenção deve ser dada à área de reforma militar. Para esse fim, a UNOGBIS e vai apoiar e dar assistência nos esforços do Governo e das Forças Armadas para planejar e implementar a reforma militar. 
Para ajudar o Governo a enfrentar esses desafios, a UNOGBIS vai trabalhar em estreita colaboração com o Coordenador Residente e a equipa das Nações Unidas no sentido de mobilizar a assistência financeira internacional. a UNOGBIS também continuará a promover ativamente o desenvolvimento de processos e mecanismos nacionais de prevenção e gestão de conflito especialmente através do reforço da capacidade das organizações da sociedade civil, incluindo grupos de mulheres, para intervir neste domínio.

Relatório de 02 de dezembro de 2005 - S/2005/752 - Durante o processo eleitoral, a UNOGBIS usou seus bons ofícios, muitas vezes em colaboração com a CEDEAO, para aliviar as tensões. Para ajudar a fortalecer a capacidade nacional de prevenção e gestão de conflitos, a UNOGBIS promoveu relações de colaboração com organizações locais, organizações não governamentais locais e internacionais, nomeadamente a War-torn Societies Project (WSP-Internacional), com sede em Genebra, e do Instituto Nacional de estudo e pesquisa da Guiné-Bissau, que completaram um projeto conjunto proposto para a implementação de um programa de investigação, de dois anos, destinado a identificar as principais fontes de tensão e as causas do conflito. Além disso, a UNOGBIS planeja organizar, para parlamentares, um programa de treinamento em resolução de conflitos e negociação, em parceria com a Organização Holandesa para o Desenvolvimento (SNV). Como já havia proposto no Relatório (S/2005/575). O Secretário volta a fazer considerações acerca da possibilidade de extensão do mandato da UNOGBIS, pois, considera que esta pode ter um papel decisivo em diversos domínios como a reforma dos serviços de segurança, a mobilização de apoio político e recursos financeiros para reforçar a capacidade dos órgãos estatais, o aprofundamento do diálogo político e da promoção do respeito pelo 
Estado de Direito e os Direitos Humanos, de forma a consolidar de forma duradoua a paz e a estabilidade na Guiné-Bissau.

A UNOGBIS prossegue os seus esforços para a melhoria do respeito ao Esatdo de Direito e aos direitos humanos. De forma a favorecer a realisação de inquéritos e processos judiciais penais e civis mais eficazes, o Gabinete organizou um curso de formação para juizes e oficiais de policias. Iniciou, também, uma série de seminários sobre o papel e a responsabilidade do procurador, para os magistrados da Procuradoria Geral.

Relatório 162 de 14 de março de 2006 - S/2006/162 - A fim de desenvolver a capacidade nacional em Transformação de Conflitos e na preparação para o programa de formação comum com a Organização de Desenvolvimento holandesa - SNV, em habilidades de liderança e transformação de conflitos para os parlamentares, a UNOGBIS, em 07 de Fevereiro, organizou um workshop de um dia de treinamentopiloto para 22 políticos, atores da sociedade civil e militares envolvidos nas iniciativas de reconciliação. Um dos objetivos do seminário foi identificar aqueles entre os participantes que poderiam ser treinados como instrutores / facilitadores neste campo. Os participantes, que foram expostos a aspectos-chave da teoria e da prática de Transformação de conflito opinaram sobre a relevância de tal formação, e por unanimidade, concordaram que uma abordagem de transformação de conflitos seria um instrumento útil para resolver a crise política do país e poderia ajudar a reunir o diálogo e várias iniciativas de paz. Com o apoio da UNOGBIS, a Comissão Nacional de Reconciliação e Reintegração das forças armadas, que foi criada em fevereiro de 2005, lançou a segunda fase de sua campanha de sensibilização em 16 de janeiro. O trabalho da Comissão foi expandido para cobrir a polícia, a segurança e outras forças paramilitares. Para consolidar os progressos feitos até agora, as atividades vão se 
concentrar, entre outros coisas, em questões como o impacto negativo da etnia nas forças armadas, o papel das forças armadas nas recentes eleições presidenciais e a necessidade de incluir no processo de reconciliação, os cidadãos da Guiné-Bissau que serviram no exército colonial Português durante a luta pela independência.

Relatório 78329 de setembro de 2006 - S/2006/783 - A UNOGBIS se prepara para lançar um projeto de capacitação de habilidades de transformação de conflitos para os parlamentares e grupos da sociedade civil, o que vai aumentar a capacidade dos agentes nacionais em incluir nos programas nacionais a prevenção de conflitos. A iniciativa será apoiada por um projeto aprovado recentemente pela Organização das Nações Unidas para a Democracia (UNDEF), que será implementado em colaboração com o Instituto Nacional Democrático dos Estados Unidos (NDI), e a SNV. A UNOGBIS continua a desempenhar um papel fundamental no apoio aos esforços nacionais no domínio da Reforma do Sector da Segurança (RSS). A equipe técnica responsável pela elaboração do documento de estratégia de reforma do setor de segurança nacional recomeçou os trabalhos após três meses de interrupção.

No período em a ser reportado, a UNOGBIS continuou suas atividades de promoção de educação para os direitos humanos escolas. O Ministério da Educação, em um despacho assinado em 28 de julho de 2006, criou uma Comissão de Coordenação Nacional de Educação em Direitos Humanos, Democracia, Cidadania, Cultura de Paz e Diálogo Intercultural. A UNOGBIS vai retomar o seu ciclo de palestras sobre os direitos humanos na Faculdade de Direito em outubro.

Relatório 946 de 06 de dezembro de 2006 - S/2006/946 - Treinamento em resolução de conflitos e tomada de decisão são parte de um projeto mais amplo de capacitação para o parlamento, submetido ao Fundo para a Democracia das Nações 
Unidas. O projeto será coordenado pela Organização das Nações Unidas para o Desenvolvimento (PNUD) e implementado pela UNOGBIS, a Organização Holandesa para o Desenvolvimento (SNV) e pelo National Democratic Institute vai incluir também a assistência técnica necessária para melhorar a capacidade de supervisão do parlamentar e pesquisar questões que afetam as mulheres e crianças, como violência baseada no gênero. Além disse, o projeto vai fornecer apoio a mulheres parlamentares que trabalhem com questões de paz fronteiriça e iniciativas de dialogo nacional.

Vai realizar a prestação de serviços de consultoria em legislação e realização de planos de trabalho para a recém-formada comissão nacional de combate à proliferação de armas ligeiras e de pequeno calibre.

A polícia civil e as unidades de direitos humanos da UNOGBIS treinaram 33 oficiais de policia nas regiões de Quinara e Tombali no sul do país em outubro sobre o Código de Conduta para os agentes da lei e sobre o uso da força e de armas de fogo.

A UNOGBIS continua desempenhar um papel importante de apoio aos esforços nacionais no campo da reforma do setor de segurança. No entanto, agendas conflitantes e salários em atraso têm dificultado o progresso no processo de revisão do sector de segurança e na elaboração de um documento estratégico de reformado setor de segurança setor nacional.

Com o objetivo de fortalecer a capacidade da mídia bissau-guineense, em desempenhar um papel construtivo no processo de consolidação da paz, a UNOGBIS elaborou um programa de cursos de treinamento, worshops sobre transformação de conflitos, reconciliação e outras atividades de sensibilização, que começaram com um curso de treinamento para 18 jornalistas de jornais públicos e privados e da rádio. 
Relatório 158 de 20 de março de 2007 - S/2007/158 - A United Nations Democracy Fund (UNDF), Aprovou um projeto com o objetivo de fortalecer o parlamento. O projeto inclui o fortalecimento de habilidades de resolução de conflitos para legisladores e um módulo especifico que contribua para aumentar o papel das mulheres parlamentares em promover a paz sustentável e o desenvolvimento. O projeto vai ser coordenado pelo Programa das Nações Unidas para o Desenvolvimento (PNUD) e implementado em conjunto com a UNOGBIS, a SNV e a National Democratic Institute of the United States. Recentemente foi formada uma Comissão Nacional de Combate à Proliferação de armar leves e de Pequeno Calibre. A Comissão inclui representantes da sociedade civil, associações de veteranos, a CEDEAO e a UNOGBIS. A UNOGBIS também trabalha com o Departamento de desarmamento para mobilizar fundos para um projeto piloto. A UNOGBIS está em busca de iniciativas que forneçam treinamento em habilidades práticas, ética e questões de paz para jornalistas de forma a permitir que a mídia trabalhe mais efetiva e imparcialmente.

Relatório 401 de 03 de julho de 2007 - S/2007/401 - Dois projetos financiados pelo Fundo para a Democracia das Nações Unidas foram lançados. O projeto de construção da paz a ser implementado pela International Peacebuilding Alliance (IPA) e o Instituto Nacional de Estudos e Pesquisa da Guiné-Bissau iniciou suas atividades em abril, com um exercício conjunto de planejamento e treinamento para consultas participativas. O Instituto começou a criação de equipes regionais para realizar um exercício de mapeamento de paz nacional através de consultas comunitárias participativas em todo o país. O segundo projeto, que visa reforçar a capacidade dos parlamentares em liderança e transformação de conflito. .

Durante o periodo em análise, progressos na esfera da reforma do setor de segurança têm sido minimos. A ultima reunião do Comitê Diretivo da Reforma do Setor de 
Segurança, que incluiu as Nações Unidas e Vários doadores, ocorreu em março. O novo governo anunciou um novo quadro organizacional para a reforma do setor de segurança em maio. O novo Comitê interministerial foi empossado em junho e tem representação da UNOGBIS. Existem duas vagas para grupos da Sociedade Civil. O Comitê técnico também membros da UNIOGBIS. Conselheiros militares da ONOGBIS apresentaram propostas ao Chefe Estado Maior General das Forças Armadas, com o objetivo de treinar oficiais a melhorar a sua eficácia na aplicação das regulamentações militares. A UNOGBIS organizou treinamento sobre Código de Conduta e o Uso da Força na região de Bolama para 15 oficiais, incluindo três mulheres. O uso do território da Guiné-Bissau como ponto de passagem de tráfico de drogas tem crescido de forma alarmante, razão pela qual, no seguimento de uma missão da UNODC a Bissau no início de março, esta se encarrega de arranjar um especialista sênior em law enforcement que irá a Bissau para ajudar no desenvolvimento de uma estratégia nacional para combater o tráfico de drogas. O especialista, cuja atribuição será financiado pelo PNUD, vai operar sob a supervisão geral do UNOGBIS.

A UNOGBIS, em parceria com a Faculdade de Direito de Bissau, organizou seminários para membros do parlamento sobre aistia e legislação existente. Os seminaries chamaram a atenção as previsões da resolução 1580 (2004) sobre Anistia, questões de Justiça e Impunidade. Os lideres parlamentares requereram mais dois seminarios adicionais sobre o mesmo assunto e aconselhamento técnico por parte da Faculdade de Direito.

Relatório 700 de 03 de dezembro de 2007 - S/2007/700 - Durante 2007, a UNOGBIS continuou a contribuir com os esforços de estabilização e reconciliação da Guiné-Bissau. Enquanto progressos encorajadores têm sido alcançados, especialmente no reforço das relações de cooperação entre os vários poderes do governo e entre os três 
principais partidos políticos, muito mais falta ainda a ser feito no sentido de consolidar e manter o impulso da governação democrática, de forma a evitar novos conflitos. Além disso, novos desafios, em particular a ameaça do tráfico de drogas e humano e o crime organizado precisam ser abordados de forma a evitar o desmoronamento das conquistas realizadas até então.

Relatório 181 de 12 de março de 2008 - S/2008/181 - No âmbito do programa de capacity-building para os parlamentares, financiado pelo Fundo para a Democracia das Nações Unidas (United Nations Democracy Fund) e coordenado pelo PNUD, a Organização para o Desenvolvimento Holandesa (SNV) e o UNOGBIS foi organizada formação em "habilidades de transformação de conflitos" (Conflict transformations skills) de 14 a 18 de Janeiro de 2008 para 15 parlamentares, incluindo duas mulheres. Quatorze parlamentares também participaram da oficina de treinamento de liderança facilitada pela SNV de 7 a 11 de Janeiro. Em 19 de Fevereiro, a SNV também ajudou a Assembleia Nacional no sentido de facilitar um workshop para promover a troca de informações entre parlamentares e outros intervenientes. Estiveram presentes 15 parlamentares, 15 representantes da sociedade civil, 15 membros da imprensa e 15 representantes do setor privado. Outro workshop, financiado pelo Fundo para a Democracia das Nações Unidas, foi realizado em 26 de Fevereiro e discutidos itens que estão na ordem do dia da sessão parlamentar, tais como impostos, governo local e mutilação genital feminina. De 11 a 16 de fevereiro de 2008, a SNV e a UNOGBIS também facilitaram a realização de um workshop financiado pelo Governo dos Países Baixos em "transformação de conflitos" para altos conselheiros políticos e militares designados pelos Gabinetes do Presidente e do primeiro-ministro, os líderes dos partidos parlamentares (PAIGC, PRS e PUSD) e do Chefe do Estado-Maior. O objectivo era o de proporcionar aos participantes as ferramentas de análise de conflitos, 
promover a confiança mútua e uma consciência da necessidade de interdependência e colaboração, e melhorar os princípios de negociação.

UNOGBIS continua a apoiar um projecto liderado pela West Africa Network para a Consolidação da Paz, sob o seu Programa mulheres na Consolidação da Paz, com o objetivo de divulgação a resolução 1325 (2000) do Conselho de Segurança sobre mulheres, paz e segurança. Um workshop sobre o tema foi organizado em 18 e 19 de Dezembro de 2007, para 30 participantes com transmissão em rádio nacional. O seminário destacou a necessidade de aumentar a participação das mulheres nos principais processos políticos nacionais, como reconciliação nacional, eleições, consolidação da paz e recuperação socio-económica. Dois planos de ação foram elaborados pela oficina, recomendando o aumento do papel das mulheres nos esforços de reconciliação no seio das forças armadas e criando um grupo para mulheres para fazer lobby junto às autoridades nacionais, para que estas adoptem e apliquem as disposições da resolução 1325 (2000) do Conselho de Segurança.

Na sequência da decisão do Conselho de Segurança em 11 de dezembro de 2007 de apoiar a inclusão da Guiné-Bissau na agenda da Comissão de Consolidação da Paz, o Comitê Organizacional da Comissão de Consolidação da Paz reuniu-se em Nova Iorque em 19 de dezembro, e concordou em incluir a Guiné-Bissau na sua agenda em um grupo de reunião sob a presidência da Representante Permanente do Brasil junto às Nações Unidas. Uma grande campanha de conscientização sobre a reforma do sector de segurança foi realizada em todas as regiões do país em dezembro de 2007 e janeiro de 2008. Os eventos contaram com a presença de membros da reforma do sector da segurança, do Comitê de Coordenação Técnica, da Comissão de reconciliação das forças armadas, a sociedade civil e a UNOGBIS entre outros. 
O censo independente do pessoal ativo das Forças Armadas, que é financiado pelo PNUD, começou em meados de fevereiro e está previsto para ser concluído até o final de março.

Relatórios S/RES/1876 (2009) e S/2009/302 - Solicita ao Secretário-Geral que estabeleça um Gabinete Integrado das Nações Unidas para a Consolidação da Paz na Guiné-Bissau (UNIOGBIS) para suceder a UNOGBIS, como recomendado por ele em seu relatório (S/2009/302) por um período inicial de 12 meses, com início em 1 de Janeiro de 2010, com as principais tarefas a seguir:

(a) Ajudar a Comissão de Consolidação da Paz na sua abordagem critica das necessidades de construção na Guiné-Bissau;

(b) Reforçar as capacidades das instituições nacionais, a fim de manter a ordem constitucional, da segurança pública e do pleno respeito ao Estado de Direito;

(c) Apoiar as autoridades nacionais no sentido de estabelecerem uma polícia eficaz e eficiente, assim como na aplicação da lei e do sistema de justiça penal;

(d) Apoiar um diálogo político inclusivo o processo de reconciliação nacional;

(e) Prestar apoio estratégico, técnico e assistência ao Governo da Guiné-Bissau no desenvolvolvimento, coordenação e implementação da reforma do sector da segurança;

(f) Ajudar as autoridades nacionais a combater o tráfico de drogas e o crime organizado, bem como o tráfico de pessoas, especialmente o tráfico de crianças;

(g) Apoiar os esforços nacionais para conter a proliferação de armas ligeiras;

h) Realizar a promoção dos direitos humanos, e o monitoramento de atividades de apoio à institucionalização do respeito pelo Estado de direito; 
(i) Integração da perspectiva de gênero na construção da paz, em linha com as Resoluções do Conselho de Segurança 1325 (2000) e 1820 (2008);

(j) Reforçar a cooperação com a União Africana, a Comunidade Econômica dos Estados do Oeste Africano (CEDEAO), a Comunidade dos Países de língua Portuguesa (CPLP), a União Europeia e outros parceiros em seus esforços para contribuir para a estabilização da Guiné-Bissau;

(k) Ajudar na mobilização da ajuda internacional;

A resolução sublinha a necessidade de se arranjar a expertise adequada para garantir que a UNIOGBIS implemente eficaz e eficientemente o seu mandato;

Salienta ainda a importância de estabelecer um gabinete inteiramente integrado, com coordenação eficaz das estratégias e programas entre as Agências das Nações Unidas, os fundos e programas, e doadores internacionais, e entre o escritório integrado, a Comunidade Económica dos Estados Oeste Africano (CEDEAO), e outras missões das Nações Unidas na sub-região, e solicita ao Secretário-Geral que tome as medidas necessárias com UNOGBIS para garantir uma transição suave entre UNOGBIS e o novo gabinete integrado;

Da análise dos relatórios do Secretário geral percebe-se que no inicio dos trabalhos a UNOBIS tinha funçções básicas e limitdas como apoiar na implementação do acordo de abuja, na criação de um ambiente propício a realização de eleições, na promoção da paz, democracia e direitos humanos, incentivar a assinatura de tratados de não proliferação de armas, enfim, funções que em muito refletem a realidade do pósguerra que se vivia no país. Posteriormente foram se ampliando os campos de ação da UNOGBIS passando a incluir a promoção da inclusão das mulheres na vida social e politica, o apoio à reforma das forças armadas, programas de DDR, apartir de 2004 
verifica-se a inclusão de programas de conscientização sobre os direitos humanos nas escolas e universidades, programas de capacity building a parlamentares e Formação para a midia.

\subsection{Importância das operações de paz e das organizações internacionais envolvidas.}

Operações de paz podem contribuir positivamente na construção de democracias estáveis a longo e médio prazo ${ }^{116}$.

Como apontado pelo Alex Bellamy, as operações de manutenção de paz podem apresentar inúmeros problemas e crises, como demonstra a sua própria história. Nos anos 1990 os diferentes governos e a maioria dos peacekeepers vergonhosamente se mantiveram à parte enquanto Ruanda, Bósnia e grandes faixas de África se consumiam. Algumas Operações de paz cometeram erros gravíssimos na Somalia, quando membros da missão abusaram de pessoas a quem supostamente deveriam proteger. Na República democrática do Congo, e na Somália, Peacekeepers foram acusados de abuso e exploração sexual de mulheres e meninas e de tráfico de armas. No entanto os relatos positivos, e os resultados concretos favoráveis são em larga escala maiores que as falhas que ocorrem no decorrer das operações.

Ainda de acordo com o mesmo autor, quando bem feitas, as operações de paz podem proteger os civis de danos, facilitar a implementação de acordos de paz e melhorar significativamente as chances de reconstrução do país. O autor chama a atenção para o fato de ainda existir bastante espaço para melhoras e falhas e abusos minam a legitimidade das operações de paz e reduzem a probabilidade de paz estável. Nesse ponto vale fazer menção ao interessante trabalho de Béatrice Pouligny, que

${ }^{116}$ BELLAMY, Alex J., WILLIAMS, Paul D., GRIFFIN, Stuart, Understanding peacekeeping, 2010, Polity Press, Pág 03. 
chama a atenção para a importância de se levar em conta a opinião das populações locais, sob pena de se realizar uma operação inefiente, porquanto fora da realidade em que vai ser operada.

O número de operações tem crescido assim como tem aumentado a sua complexidade, o que corrobora as afirmações anteriore e demonstra que tem sido feita uma escolha pelo mecanismo em termos de busca pela paz.

Para Alex Bellamy ${ }^{117}$, a manutenção da paz é o principal instrumento de gestão de conflitos violentos da sociedade contemporânea internacional. Os autores argumentam que as operações de manutenção da paz não se desenvolveram de forma linear e que a ONU realizada diferentes tipos de missões em diferentes momentos e partes do mundo, decorrendo desse aspecto a identificação de sete tipos diferentes de operações de manutenção de paz. No caso da Guiné-Bissau, pode-se perceber, principalmente pela análise dos Relatórios do Secretário-Geral, que apesar do discurso retórico ser maior, este é sim acompanhado de esforços realizados no sentido da busca pela paz, e pela instauração do Estado de Direito e da Democracia. No caso, as operações de paz constituem o principal mecanismo de justiça de transição, e têm demonstrado ser um método importante, senão necessário na construção da paz. As reformas em áreas chave, apesar de constantemente interrompidas, têm permitido avanços significativos na melhora de condições dos antigos combatentes, na melhora de instrução das forças de policia e de segurança e do funcionalismo do setor judiciário.

${ }^{117}$ BELlaMY, Alex, Op. Cit, Pág 14. 


\section{JUSTIÇA DE TRANSIÇÃO COMO INSTRUMENTO DA PAZ E DA}

\section{DEMOCRACIA}

\subsection{Os Esforços de (re) construção da paz}

Ao final da guerra de 1998/1999, as ajudas providas à Guiné-Bissau estavam nas mãos de um restrito grupo de doadores, como a União Europeia, Portugal, França, Cuba e a Organização das Nações Unidas, especialmente após 2006, e com as constantes crises assinaladas o grupo aumentou, incluindo o Brasil, a Espanha e Angola. Estes têm desenvolvidos papéis em medidas paliativas e de curto prazo, que poucos resultados têm apresentado para fazer frente às constantes crises, e de medidas de longo prazo que ainda estão em funcionamento. De entre as medidas de longo prazo, os principais programas são a UNOGBIS (UNIOGBIS) ${ }^{118}$ e o Peacebuilding Fund ${ }^{119}$. Para Silvia Roque $^{120}$, até ao presente, as politicas de peacebuilding se têm provado irrelevantes ou incapazes de prevenir instabilidades a longo prazo. A falta de politicas de longo termo relevantes é normalmente justificada pela fragilidade do Estado e má governação. A autora elenca como outros motivos que dificultam a plena realização dos processos de peacebuilding, o fato de os projetos de coordenação de ajuda ao desenvolvimento serem

118 A UNOGBIS ou UN Peacebuilding office for Guinea-Bissau foi criada no dia 3 de Março, pelo Conselho de Segurança das Nações Unidas. Este aprovou a criação da Missão das Nações Unidas para o Apoio à Reconstrução da Paz na Guiné-Bissau (UNOGBIS), a ser chefiada por um Representante Especial do Secretário-Geral. A UNOGBIS foi criada com a função de coordenar todo o trabalho do sistema das Nações Unidas na Guiné-Bissau durante o período de transição até à realização das Eleições. Após o período de conflito e dadas as constantes instabilidades, se verificou a necessidade de se manter a missão de paz, pelo que o mandato foi prorrogado, com a função de formular uma estratégia de peacebuilding que fosse referência para o Sistema das Nações Unidas, para os atores nacionais, regionais, internacionais, Instituições financeiras e Sociedade Civil. O Programa tem por áreas de intervenção o monitoramento politico, reforma no setor da defesa e segurança, reforço das capacidades dos setores da sociedade e governo em busca da prevenção e resolução dos conflitos, reforma da administração pública

119 O Peacebuilding Fund - UN Peacebuilding Commission. Tem por mandato estabelecer um panorama estratégico com a contribuição de atores internacionais, incluindo ações de curto-prazo. Intervêm nas áreas de consolidação do Estado de Direito, promoção de treinamento técnico profissional e emprego para os jovens, e apoio às populações mais vulneráveis.

${ }^{120}$ ROQUE, Sílvia Peacebuilding in Guinea-Bissau: a critical approach, NOREF Report. Norwegian Peacebuilding Center, 2009. Pág. 11. 
mais discursivos que reais; os investimentos são baixos e condicionados; a falta de informação dos atores internacionais sobre a realidade do país; o fato de até então não se ter decidido por uma forma de lidar com a violência do passado (o que talvez seja explicado se se considerar que ainda se está em transição, o que se discutirá mais para a frente), o fato de não haver conexão entre o discurso e a prática, na medida em que muitos projetos terminam no nível das intenções; o fato de haver, nas palavras da autora, uma "crescente despolitização das analises e intervenções pós guerra". Para Silvia Roque ${ }^{121}$, a consolidação da paz na Guiné-Bissau enfrenta grandes desafios, tanto no nível nacional, quanto no nível internacional, em grande parte porque o foco da UNIOGBIS é principalmente o tráfico de drogas e a reforma do setor de segurança, ainda de acordo com a autora, intervenções centradas sobre causas mais visíveis e imediatas tendem a esquecer a criação de condições sociais necessárias para sustentar a paz. De novo, a partir da análise dos relatórios do Secretário-Geral pode-se perceber que efetivamente, a UNIOGBIS, tem envidado diversos esforços na implantação de medidas naqueles que considera serem os setores chave, que permitirão a contrução de uma paz duradoura. Vale dizer que a implemntação de tais medidas depende em grande parte da própria vontade política interna. Vale também chamar a atenção para o fato de geralmente a expertise utilizada pela organização ser estrangeira, o que talvez dificulte a real identificação dos problemas que dificultam a aplicação e eficácia de várias medidas implementadas.

\subsection{O papel das organizações da sociedade civil na construção da paz.}

Não se pode falar em tentativa de construção da paz, sem que se tenha em atenção o importante papel que as Organizações da Sociedade Civil desempenharam e têm desempenhado ao longo do processo de desenvolvimento do país, principalmente

\footnotetext{
${ }^{121}$ ROQUE, Silvia, Op. Cit. Pag. 20.
} 
no período de Transição Política pós-guerra ${ }^{122}$. As Organizações Não Governamentais têm ajudado as populações organizando-as, promovendo ações de formação e de acesso aos meios materiais, financeiros e humanos que lhes têm permitido melhorar as suas condições de trabalho, de saúde, de educação e de vida em geral e têm sido parceiros de crucial importância na construção de um clima de diálogo, democracia, paz e reconciliação $^{123}$. As Organizações da Sociedade Civil, dadas as fragilidades impostas pelas constantes crises políticas e militares que têm assolado o país têm se implicado de forma ativa em todo o processo de transição política assumindo um papel de facilitadores do diálogo e de mediadores entre os diferentes interesses políticos, militares e civis, sempre com o objetivo da busca de soluções pacíficas, justas e duradoira, mantendo-se fiéis aos seus princípios de justiça social, defesa de uma cidadania livre, participativa e responsável. Estas consideram ainda que o diálogo e a inclusão dos diferentes atores nacionais, a colaboração e o apoio da comunidade internacional são primordiais para a construção da paz, justiça e tranquilidade social tão almejado na Guiné-Bissau. Sem estas conquistas de base jamais o país poderá sonhar com o progresso social e um desenvolvimento que se quer inclusivo, contínuo e durável.

\footnotetext{
${ }^{122}$ HANDEM, Jamel, Op. Cit. Pág. 2.

${ }^{123}$ Durante o conflito político-militar de 7 de Junho de 1998, através da Célula das ONG Nacionais e Estrangeiras para a Gestão da Crise na Guiné-Bissau (CECRON) e do núcleo das Organizações Não Governamentais se criaram mecanismos de ajuda aos refugiadas no estrangeiro, e à distribuição de gêneros alimentícios no país.

Durante o regime do deposto Presidente Koumba Ialá, em que se registaram diversos atropelos a Constituição da República, com prisões arbitrárias de líderes políticos, magistrados do Supremo Tribunal da Justiça, ativistas da Liga Guineense dos Direitos Humanos, jornalistas, fecho de órgãos de comunicação social, foram as tais organizações que tiveram papel importante em denunciar os abusos.

Durante os acontecimentos de 14 de Setembro de 2003 que levaram ao afastamento do ex-presidente Koumba Ialá, as Organizações mencionadas participaram ativamente na «Comissão Ad Hoc» que elaborou a «Carta de Transição Política» que regeu o país durante o período de "transição Politica" findo; Nas diversas eleições realizadas desde a guerra de 7 de junho, tais Organizações foram as principais responsáveis pela promoção de campanhas diretas de educação cívica junto às populações de base, programas radiofónicos com vista a sensibilização do eleitorado para uma participação massiva, ordeira, livre e consciente no ato eleitoral e também apelando aos Partidos Políticos para que aceitem democraticamente o veredicto das urnas.
} 
Vale a título final, no âmbito da relação entre operações de paz e justiça de transição, ressaltar o debate que se tem iniciado no âmbito do International Center for Transitional Justice (ICTJ) sobre a ampliação do conceito de justiça de transição. Essa ampliação reforça idéia da inclusão das operações de paz, que consituem importante mecanismo na busca pela paz. Essa tentativa de evolução do conceito de justiça de transição se deve principalmente, à nova realidade que o mundo vive, diferente daquela do pós-Segunda Guerra. Se naquela época os diferentes países se viam frente à reconstrução do Estado e à busca de justiça criando mecanismos que condenassem o passado abusivo e criassem um novo marco zero em busca da democracia, atualmente, a idéia de reconstrução se encontra muito associada a aspectos de desenvolvimento e liberdade. A antiga Alta Comissária das Nações Unidas para os Direitos humanos, Louise Arbour ${ }^{124}$, por exemplo, defendeu a integração dos Direitos Econômicos, sociais e culturais no quadro geral da justiça de transição, pois assim se cria,

"o salto gigantesco que permitiria que a justiça, em seu sentido pleno, realizasse a devida contribuição para sociedades em transição ${ }^{125,}$

Ainda de acordo com Pablo de Greiff, em 2008, a International Journal of Transitional Justice dedicou uma edição especial ao tópico da Justiça de transição e Desenvolvimento, na qual um número considerável de colaboradores argumentaram pela expansão da alçada da justiça de Transição de forma a incluir aspectos de desenvolvimento. Zenaida miller defende que : o divórcio de estratégias de desenvolvimento, da justiça transicional permite que se forme um mito de que origens de conflitos são políticas ou étnicas, ao invés de econômicas ou por recursos naturais,

\footnotetext{
${ }^{124}$ GREIFF, Pablo de, DUTHIE, Roger (Ed.) Op. Cit, Pág. 19.

125 Tradução livre de: "The gigantic leap that would allow justice, in its full sense, to make the contribution that it shoul to societies in transition".
} 
ou que a necessidade de memorizar o passado não requeira a narração de opressão econômica ocorrida no passado.

Ainda de acordo com o mesmo autor ${ }^{126}$, Tem sido apontado que a Justiça de transição pode impactar o desenvolvimento em alguns aspectos, mesmo mantém o foco sobre as violações dos direitos civis e políticos direitos, sem abordar explicitamente as questões de desenvolvimento ou buscando resultados do desenvolvimento. Jane Alexander, por exemplo, sugere que a justiça de transição pode ter um impacto positivo no desenvolvimento por efeito direto ajudando a criar as condições que podem facilitar o desenvolvimento. Em primeiro lugar, através de medidas como reparações individuais e coletivas, restituição da propriedade (como ocorreu em Ruanda), reabilitação e reintegração de vítimas e agressores à sociedade, medidas de justiça de transição que podem aliviar a marginalização, exclusão e vulnerabilidade, trazendo pessoas e grupos à economia, reconhecendo e fortalecendo-os como cidadãos e, talvez, gerar atividade econômica. Segundo, quatro condições-chave: estabilidade social e política, segurança, acesso à justiça; prevenção de conflitos e justiça social e econômica. essas quatro condições chave que podem estimular o desenvolvimento, podem ser facilitadas por objetivos de justiça de transição, como tratar queixas, grupos de reconciliação, restauração e confiança nas instituições.

${ }^{126}$ GREIFF, Pablo de, DUTHIE, Roger (Ed.), Op. Cit. Pág. 20. 


\section{CONCLUSÃO}

De toda a discussão colocada ao longo do trabalho, pode-se depreender que a questão da implementação de medidas de transição na Guiné-Bissau, assume características peculiares.

As constantes sublevações e os ciclos de violência, verificados após a guerra de libertação colonial, que influênciaram e culminaram com o conflito político militar de 1998, dificultam a instauração de medidas transicionais efetivas, que como exposto durante o trabalho, exigem a existência de um mínimo de valores que a embasem de forma a torná-la possível.

A análise do papel da operação de manutenção de paz instituída pela ONU, através das atividades por estas praticadas, demonstra que existe sim, a implementação de mecanismos de justiça de transição, que visam a desenvolver uma paz sustentável e a criar instituições mínimas que garantam o Estado de Direito e a Democracia.

No entanto, apesar de serem vários os esforços envidados, no sentido da busca pela paz e reconstrução do país, os resultados se encontram aquém do esperado, dada a frequente recorrência a medidas antidemocráticas, acima mencionada.

Os Mecanismos de justiça de transição implementados na Guiné-Bissau, à semelhança da situação exposta por Lydiah Kemunto Bosire, quando fala dos países africanos, têm apresentado pouca eficácia.

A questão das dificuldades de implementação de mecanismos de justiça transicional, chama a atenção para se levar em conta a idéia defendida por Beatrice Pouligny, em sua obra, Ils nous avaient promis La paix, de que é necessário levar em 
conta a realidade local. Os mecanismos a serem implantaados precisam ser criados de dentro pra fora e não o contrário.

Ainda sobre as dificuldades de implementação de mecanismos de transição, Lydiah Kemunto Bosire ${ }^{127}$ explica que para que medidas transicionais possam ser mais efetivas, deve-se encurtar a distância entre as expectativas e a realidade, tendo expectativas mais modestas a respeito do que as medidas de busca de justiça podem proporcionar; avaliar de modo realista as condições institucionais necessárias para sua implementação bem-sucedida; e investir numa reforma institucional significativa que implique na reconstrução de instituições. Por outro lado, devem-se perseguir caminhos alternativos, complementares, não estatais, para promover a reconciliação - incluindo iniciativas localizadas, informais, que exijam pouco das instituições estatais, ou iniciativas regionais na União Africana.

Nos termos da autora, a justiça transicional é tipicamente entendida dentro do contexto legal de responsabilidades do Estado, com a pressuposição implícita de um modelo de Estado institucionalizado, com seus órgãos "não coagidos pela dinâmica das pressões sociais", numa sociedade composta por cidadãos cujas relações são mediadas pela lei mais do que por outros meios, como o parentesco. As medidas de justiça transicional, então, procuram em primeiro lugar criar ou restaurar a confiança entre o Estado e os cidadãos que se ajustam a certos parâmetros.. Em outras palavras, esforços no sentido de formalizar o Estado e estabelecer condições nas quais os cidadãos possam estar suficientemente comprometidos com as normas e valores que motivaram suas instituições vigentes, que é o que as medidas de justiça transicional procuram fazer, podem ir contra as práticas de um Estado no qual os governantes se beneficiem de um equilíbrio informal.

\footnotetext{
${ }^{127}$ BOSIRE, Lydiah Kemunto, Op. Cit. Pág. 90.
} 
Em Estados com instituições fracas, uma das consequências não pretendidas de algumas medidas de justiça transicional é que elas podem conferir "uma aparência de legitimidade a governantes que na verdade evitam a democratização e a vigência da lei”, permitindo que os líderes "falem em princípios de direitos humanos da boca para fora" sem substanciais mudanças no encaminhamento político. Ou seja, existe um grau mínimo de institucionalização do Estado acima do qual as políticas estatais, incluindo as medidas de justiça transicional, podem ser mais eficazes. Tudo indica ser esta uma das principais dificuldades da Guiné-Bissau.

Por mais que as medidas de justiça transicional sejam implementadas a fim de fortalecer as instituições estatais, seu sucesso na prática depende da existência prévia de instituições estatais operantes. Esta conclusão pede uma avaliação exaustiva da base institucional dos países em transição antes de partir para a implementação da justiça transicional, pede que sejam alimentadas expectativas extremamente modestas a respeito do que é possível conseguir, e pede ainda uma exploração de paradigmas alternativos e/ou complementares para combater a impunidade e promover a reconciliação. Em última instância, é necessária, imperativamente a priorização da reforma - ou (re)construção - das instituições estatais, e a comunidade internacional deve estar preparada para apoiar tais demandas com os recursos adequados.

Tendo isso em mente como uma leitura possível e real das condições do Estado guineense, é possível analisar porque a implementação das medidas de justiça transicional tem tido imensas dificuldades em vingar.

A precariedade das instituições, mais do que o discurso retórico se revela fundamental para o baixo desempenho das medidas de justiça transicional. 
No caso guineense, apesar das dificuldades, cujas motivações podem encontrar respaldo nos argumentos acima expostos, as medidas de justiça de transição se fazem ainda mais importantes, na medida em que, desde sempre é utilizado o argumento das crises passadas para justificar as crises atuais, nessa medida, a criação e realização de mecanismos para se fazer frente ás crises anteriores como comissões de verdade, investigações históricas e as reformas intitucionais que permitiriam que se afastassem do poder os perpetradores das crises anteriores, seriam de mais valia à quebra desse argumento e das situações pelas quais se justifica. Quer-se com isso demonstrar que, não obstante a dificuldade de implementação das medidas transicionais, estas se apresentam importantes na resolução dos problemas do país, cabendo atacar os motivos da ineficiência já mencionada.

Vale, ainda, dizer que identificar as possíveis origens das dificuldades enfrentadas pela justiça transicional pode não proporcionar soluções imediatas, mas funciona como indicador da oportunidade de centrar o foco na construção da capacidade do Estado e de suas instituições, a fim de que ele seja capaz de promover a justiça e os direitos humanos. E é nesses termos que é entendida a importância da instituição de mecanismos de busca pela paz e reconstrução da Guiné-Bissau. 


\section{REFERÊNCIAS BIBLIOGRÁFICAS}

AKHAVAN, Payam, The international criminal tribunal for Rwanda, The American Journal of International Law, Vol. 90, N. 03, p. 501-510, 1996.

AMBOS, Kai. El marco jurídico de la justicia de transición. In: MALARINO, Ezequiel; ELSNER, Gisela (Org.). Justicia de Transición: com informes de América Latina, Alemania, Italia y España. Montevideo: Fundación Konrad-Adenauer-Stiftung, 2009.

ARBOUR, Louise. Economic and Social Justice for Societies in Transition, Journal of International Law and Politics, 40:1, 2008.

ARENDT, Hannah, Entre o passado e o futuro, Ed. Perspectiva, 2005.

AUGEL, Johannes, MEYNS, Peter, Processos de transição na África lusófona, In Soronda Revista de Estudos Guineenses, Nova série, n. o 5, Pp. 7-50, 2002.

BAINES, Erin K, The Haunting of Alice: Local Approaches to Justice and Reconciliation in Northern Uganda, The International Journal of Transitional Justice, $1,2007$.

BELlAMY, Alex J., WILlIAMS, Paul D., GRIFFIN, Stuart, Understanding peacekeeping, Polity Press, 2010.

BIZAWU, Sébastien Kiwonghi, O Conselho de Segurança da ONU e os conflitos nos Grandes Lagos: análise seletiva e interpretativa das resoluções sobre o Congo, Manole Ed., Barueri, 2008.

BLEEKER, Mô, La justice transitionnelle dans le monde francophone: état des lieux, Département fédéral des affaires étrangères, Confédération suisse, 2007. 
BORAINE, Alexander L., Transitional Justice: A Holistic Interpretation, Journal of International Affairs, 60:1, Fall 2006.

BOSIRE, Lydiah Kemunto, Grandes promessas, pequenas realizações: justiça transicional na África subsaariana, Revista internacional de direitos humanos: SUR, São Paulo, v. 3, n. 5, 2006.

CARDOSO, Carlos A transição democrática na Guiné-Bissau: um parto difícil, In: Transitions liberales en Afrique lusophone, Paris, Ed. Karthala, Pp. 259-285, 1995. Compreendendo a crise de 07 de junho na Guiné-Bissau, In Soronda Revista de Estudos Guineenses, Edição Especial 07 de Junho, Pp. 87-104, 2000. Transição democrática na Guiné-Bissau e outros ensaios, Instituto Nacional de Estudos e Pesquisa, Bissau, 1996.

Para uma leitura sociológica da Guiné-Bissau, Instituto Nacional de Estudos e Pesquisa, Bissau, 1988.

CLARK, Phil. Hybridity, Holism and 'Traditional' Justice: The Case of the Gacaca Courts in Post-Genocide Rwanda, George Washington International Law Review, 39, 2008.

DERRIDA, Jaques. $\mathrm{O}$ perdão, a verdade, a reconciliação: qual gênero? In NASCIMENTO, Evandro (org.), DERRIDA, Jacques, Pensar a desconstrução, São Paulo, Estação Liberdade (Ed.).

DIMOULIS, Dimitri. Justiça de transição e função anistiante no Brasil: hipostasiações indevidas e caminhos de responsabilização. In MARTINS, Antonio; SWENSSON 
JUNIOR, Lauro Joppert (Org.). Justiça de transição no Brasil: direito, responsabilização e verdade. São Paulo, Saraiva, 2010.

DJALÓ, Iaguba, O conflito politico militar na Guiné-Bissau e os desafios da reconstrução e recuperação da memória e da identidade nacional, In Soronda Revista de Estudos Guineenses, nº, pág. 97-107, 2004.

DJALÓ, Tcherno, Lições e legitimidade dos conflitos políticos na Guiné-Bissau, In Soronda, Revista de Estudos Guineenses, Edição Especial 07 de Junho, 2000.

ELSTER, John, Closing the Books: Transitional Justice in Historical Perspective, Cambridge University Press, New York, 2004

FRANÇA, Julia Monteath de. A Transição Democrática e a Construção da Memória Política na África do Sul e na Argentina. Revista Eletrônica Boletim do Tempo, Ano $5, \mathrm{~N}^{\circ} 05,2010$.

GATES, Scott, Post-conflict justice and sustainable peace, Washington, Banque Mondiale, 2006.

GOMES, Antonieta Rosa, O poder militar e a desedificação do estado de direito e da democracia na Guiné-Bissau. In $7^{\circ}$ Congresso Ibérico de Estudos Africanos, Lisboa, 2010 - 50 anos das independências africanas: desafios para a modernidade, Lisboa: CEA, 2010, Disponível em: http://hdl.handle.net/10071/2347, Acesso em: 17/06/2011.

GREIFF, Pablo de, Repairing the Past: Compensation for Victims of Human Rights Violations, In GREIFF, Pablo de, The Handbook of Reparations, New York: Oxford University Press, 2006. 
GREIFF, Pablo de, DUTHIE, Roger (Ed.), Transitional Justice and Development:

Making Connections (Advancing Transitional Justice), Social Science Research Council, 2009.

HAYNER B, Priscilla, Commission Vérité : un aperçu schématique, Revue internationale de la Croix-Rouge, Numéro 862, pp. 295-310.

Unspeakable Truths: Transitional Justice and the Challenge of Truth Commissions, New York: Routledge, 2010.

HAZAN, Pierre, Mesurer l'impact des politiques de châtiment et de pardon : plaidoyer pour l'évaluation de la justice transitionnelle, In Revue internationale de la CroixRouge, Numéro 861.

HOURQUEBIE, Fabrice, La notion de justice transitionnelle - a-t-elle un sens ?, Toulouse.

HOROWITZ, David, The Latest Civil Rights Disaster: Ten Reasons Why Reparations are a Bad Idea, and Racist, Too, Salon, 2000, Disponível em: http://www.salon.com/news/col/horo/2000/05/30/reparations.

HUMPHREY, Michael. International Intervention, Justice and National Reconciliation: The Role of the ICTY and ICTR in Bosnia and Rwanda. Journal of Human Rights 2:4, 2003.

HUYSE, Luc, SALTER, Mark, Traditional Justice and Reconciliation After Violent Conflict: Learning from African Experiences, Stockholm, IDEA, 2008.

JAUARÁ, Manuel, Análise do processo de transição democrática na África Lusófona: o caso Guiné-Bissau, São Paulo, 2003. 
KOUDAWO, Fafali, Cabo-Verde e Guiné-Bissau: Da Democracia Revolucionária á

Democracia Liberal, Instituto Nacional de Estudos e Pesquisas, 2001.

KERR, Rachel and EIRIN, Mobekk. Peace and Justice: An Introduction, Peace \& Justice: Seeking Accountability After War, Cambridge: Polity Press, 2007.

KRIGER, Norma, Traditional Justice as Socioeconomic Rights, Peace Review, 12:1, March 2000.

LEFRANC, Sandrine, Après le conflit, la réconciliation ?, Ed. Michel Houdiard, Paris, 2006.

LOPES, Nelson, As forças armadas num Estado em "Interrogação": Os Entraves À Construção E Consolidação Do Estado na Guiné- Bissau, In $7^{\circ}$ Congresso Ibérico de Estudos Africanos, Lisboa, 2010 - 50 anos das independências africanas: desafios para a modernidade, Lisboa: CEA, 2010, Disponível em: http://hdl.handle.net/10071/2347, Acesso em: 17/06/2011.

MARTINS, Antonio (org.), Justiça de Transição no Brasil - Direito, Responsabilização e Verdade, Editora Saraiva, 2010.

MANI, Rama. Dilemmas of Expanding Transitional Justice, or Forging the Nexus Between Transitional Justice and Development. In International Journal of Transitional Justice, 2:3, 2008.

MAYER-RIECKH, Alexander, GREIFF, Pablo de, Justice as prevention- Vetting public employees in transitional societies, ICTJ, 2007.

MCVOY, Kieran, Beyond Legalism: Towards a Thicker Understanding of Transitional Justice, Journal of Law and Society, 34:4, 2007. 
MILLER, Zinaida. Effects of Invisibility: In Search of the 'Economic' in Transitional Justice, In International Journal of Transitional Justice, 2:3, 2008.

MÓDULO DE PAULA, Luiz augusto, Genocídio e o Tribunal Penal Internacional para Ruanda, São Paulo, 2011.

MUVINGI, Ismael, Sitting on Powder Kegs: Socioeconomic Rights in Transitional Societies, In International Journal of Transitional Justice, 3.2, 2009.

NAQVIN, Yasmin, Le droit à la vérité en droit international : réalité ou fiction, Revue internationale de la Croix-Rouge, Numéro 862.

NEVES, Gilda Motta Santos, Comissão das Nações Unidas para Consolidação da Paz: perspectiva brasileira, Brasília, FUNAG, 2009, Pág. 54

NSANZUWERA, Francois-Xavier. The ICTR Contribution to National Reconciliation. Journal of International Criminal Justice, 3:4, 2005.

OLSON M, Laura, Réveiller le dragon qui dort ? Questions de justice transitionnelle: répression pénale ou amnistie ?, Revue internationale de la CroixRouge, Numéro 862.

PERRONE-MOISÉS, Cláudia, O perdão e os crimes contra a humanidade: um diálogo entre Hannah Arendt e Jacques Derrida, In: CORREIA, Adriano (Org.) Hannah Arendt e a condição Humana, Salvador, Quarteto, pp. 211-224, 2006.

PETRUS, Gabriel Merheb, A Justiça de transição como realização do Estado Democrático de Direito: caminhos para a desconstrução político-jurídica do legado autoritário no Brasil, In Revista Anistia Politica e Justiça de Transição, Ministério da Justiça, Brasilia, V. 3, 2010. 
PHILIPPE, Xavier, Les Nations Unies et la justice transitionnelle : bilan et perspectives, Observateur des Nations Unies, Numéro 20/21, 2006.

PINTO, Simone Martins Rodrigues, Justiça transicional na África do Sul: restaurando o passado, construindo o futuro, Contexto Internacional, vol.29 no.2, Rio de Janeiro, 2007.

PIOVESAN, Flávia Piovesan, Direitos Humanos: memória, verdade e justiça. Teoria e Debate $\mathrm{n}^{\circ} 87 \quad$ - março/abril 2010, Disponível em: http://www.fpabramo.org.br/o-que-fazemos/editora/teoria-e-debate/direitos-humanosmemoria-verdade-e-justica, Acessado em: 23/06/2011.

PRUNIER, Gérard, The Rwanda Crisis: History of a Genocide, New York, Columbia University Press, 1995, p. 398

QUINN, Joanna, Social Reconstruction in Uganda: The Role of Informal Mechanisms in Transitional Justice. Human Rights Review, 8:4, 2007.

ROHT-ARRIAZA, Naomi, Reparations Decisions and Dilemmas, Hastings International and Comparative Law Review, 27, 2004.

ROQUE, Sílvia, Peacebuilding in Guinea-Bissau: a critical approach, NOREF Report. Norwegian Peacebuilding Center, 2009.

ROSE, Cecily; SSEKANDI, Francis M. A procura da justiça transicional e os valores tradicionais africanos: um choque de civilizações - o caso de Uganda, Revista. Internacional de Direitos Humanos, SUR. São Paulo, v. 4, n. 7, 2007.

ROSOUX, Valérie, Le cas des gacaca au Rwanda. Jusqu'où négocier la réconciliation?, Négociations, $\mathrm{N}^{\circ} 9,2008$. 
ROTBERG, Robert Irwin, Truth comissions and the provision of truth, justice and reconciliation, Princeton, 2000.

SANGREMAN, Carlos; SOUZA, JR., Fernando; ZEVERINO,Guilherme; BARROS, Miguel, A evolução política recente na Guiné-Bissau: As eleições presidenciais de 2005, Os conflitos, O desenvolvimento, A sociedade civil: Colecção Documentos de Trabalho, $\mathrm{n}^{\mathrm{o}} 70$, Centro de Estudos sobre África e do Desenvolvimento do Instituto Superior de Economia e Gestão da Universidade Técnica de Lisboa, Lisboa, 2006.

SANTOS, Cecília MacDowell. A justiça ao serviço da memória: mobilização jurídica transnacional, direitos humanos e memória da ditadura. In TELES, Edson; TELES, Janaína de Almeida (Org.). Desarquivando a ditadura: memória e justiça no Brasil. v.2. São Paulo: Hucitec, 2009.

SEMEDO, Rui Jorge, O Estado da Guiné-Bissau e os seus desafios político institucionais. Os Entraves À Construção E Consolidação Do Estado na GuinéBissau, In $7^{\circ}$ Congresso Ibérico de Estudos Africanos, Lisboa, 2010 - 50 anos das independências africanas: desafios para a modernidade, Lisboa: CEA, 2010, Disponível em: http://hdl.handle.net/10071/2347, Acesso em: 17/06/2011.

SIEFFERT D, Les jalons d'un colloque. Amnésie...amnistie...impunité...justice transitionnelle, Mouvements, Numéro 53, 2001.

SIKKINK, Kathryn, WALLING, Carrie Booth, The Emergence and Impact of Human Rights Trials, In Latin America, Journal of Peace Research, , vol. 44, no. 4, July 2007.

SILVA, Virgílio Afonso da, Transição e direito: culpa, punição, memória in, GALLE, Helmut, SCHMIDT, Rainer Schmidt (orgs.), A memória e as ciências humanas, São Paulo: Humanitas, 2011. 
SOARES, Inês Virgínia Prado, Memória e Verdade: A Justiça de Transição no Estado Democrático Brasileiro, Editora: Fórum, 2010.

SOOKA, Yasmin, Dealing with the past and transitional justice: building peace through accountability, International Review of Red Cross, Vol. 88, n 862, 2006.

TEITEL, Ruti G., The Law and Politics of Contemporary Transitional Justice, In Cornell International Law Journal, Vol. 38, p. 837, 2005.

Transitional Justice in a New Era, Fordham International Law Journal, Volume 26, Issue 4, 2002.

Transitional Justice Genealogy, Harvard Human Rights Journal, Vol.16, N.69, 2003.

Editorial Note - Transitional Justice Globalized, In The international Journal of Transitional Justice, Oxford Journals, Volume 2, Issue 1.

TODOROV, Tzvetan, Os limites da justiça, In CASSESSE, Antonio e DELMASMARTY, Mireille (org.), Crimes internacionais e jurisdições internacionais, São Paulo, Manole, 2004.

TUTU, Desmond, No future without forgiveness. Nova York: Image, 2000.

WADDELL, Nicholas, CLARK, Phi, Courting Conflict? Justice, Peace and the ICC in Africa, Royal African Society, 2008.

ZYL, Paul Van, Promovendo a justiça transicional em sociedades pós-conflito, In Revista Anistia Política e Justiça de Transição, (jan. / jun. 2009). Brasília, Ministério da Justiça, 2009. 